\title{
HYDROLOGIC ANALYSIS OF THE PROPOSED BADGER-BEAVER CREEKS ARTIFICIAL-RECHARGE PROJECT, MORGAN COUNTY, COLORADO
}

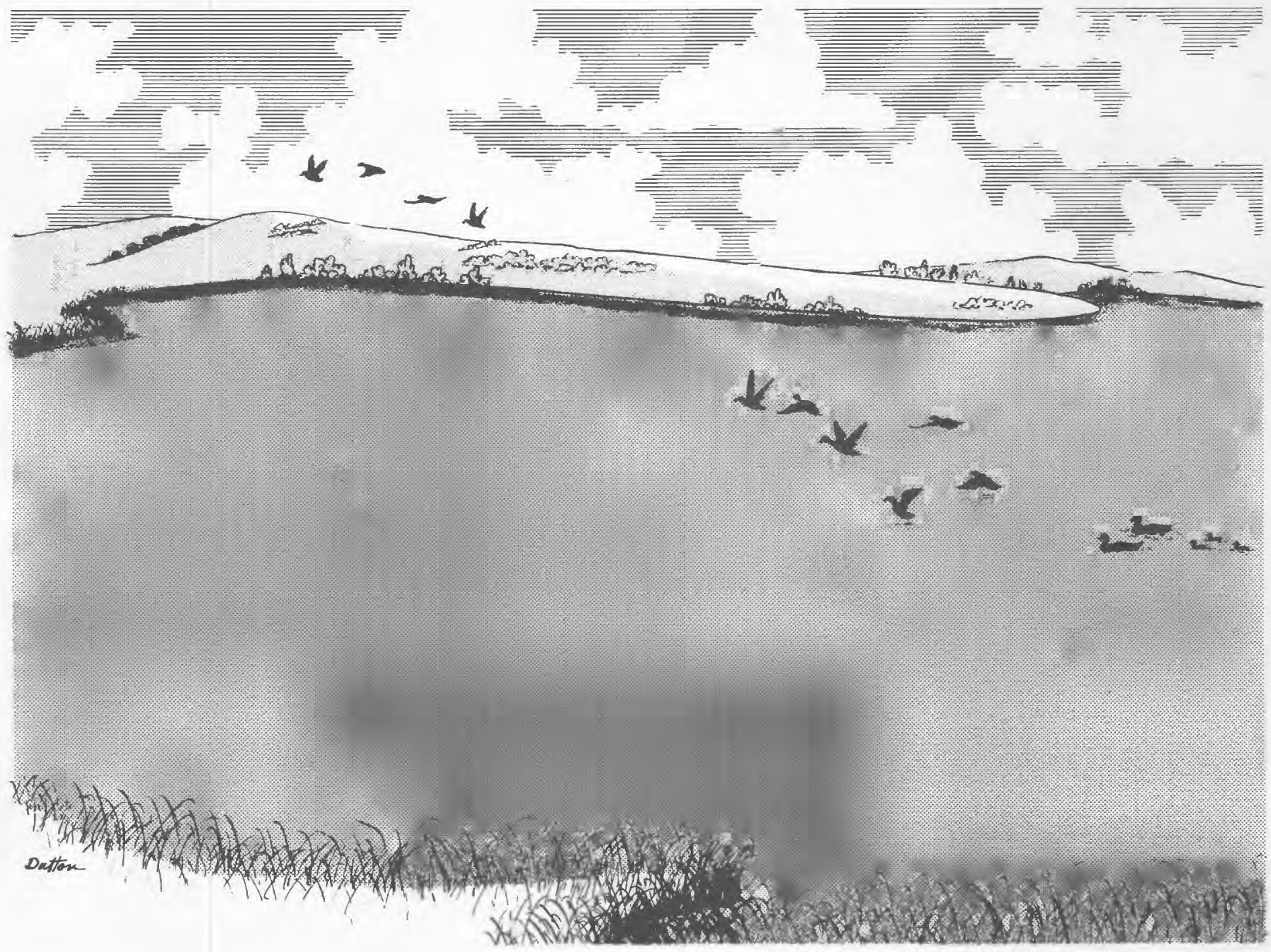

U.S. GEOLOGICAL SURVEY

Water Resources Investigations 80-46

Prepared in cooperation with the U.S. Fish and Wildlife Service
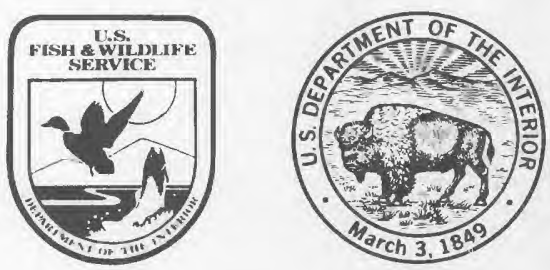


\begin{tabular}{|c|c|c|}
\hline $\begin{array}{l}\text { REPORT DOCUMENTATION } \\
\text { PAGE }\end{array}$ & 1. REPORT NO. & 3. Recipient's Accession No. \\
\hline \multirow{2}{*}{\multicolumn{2}{|c|}{$\begin{array}{l}\text { 4. Title and Subtitie } \\
\text { HYDROLOGIC ANALYSIS OF THE PROPOSED BADGER-BEAVER CREEKS } \\
\text { ARTIFICIAL-RECHARGE PROJECT, MORGAN COUNTY, COLORADO }\end{array}$}} & $\begin{array}{l}\text { 5. Report Date } \\
\text { July } 1980\end{array}$ \\
\hline & & 6. \\
\hline \multicolumn{2}{|l|}{$\begin{array}{l}\text { 7. Author(s) } \\
\text { A. W. Burns }\end{array}$} & $\begin{array}{l}\text { 8. Performing Organization Rept. No. } \\
\text { USGS/WRI } 80-46 \\
\end{array}$ \\
\hline \multirow{2}{*}{\multicolumn{2}{|c|}{$\begin{array}{l}\text { 9. Performing Organization Name and Address } \\
\text { U.S. Geological Survey, Water Resources Division } \\
\text { Box } 25046 \text {, Mail Stop } 415 \\
\text { Denver Federal Center } \\
\text { Lakewood, C0 } 80225\end{array}$}} & 10. Project/Task/Work Unit No. \\
\hline & & $\begin{array}{l}\text { 11. Contract(C) or Grant(G) No. } \\
\text { (C) } \\
\text { (G) }\end{array}$ \\
\hline \multirow{2}{*}{\multicolumn{2}{|c|}{$\begin{array}{l}\text { 12. Sponsoring Organization Name and Address } \\
\text { U.S. Geological Survey, Water Resources Division } \\
\text { Box } 25046 \text {, Mail Stop } 415 \\
\text { Denver Federal Center } \\
\text { Lakewood, co } 80225\end{array}$}} & $\begin{array}{l}\text { 13. Type of Report \& Period Covered } \\
\text { Final }\end{array}$ \\
\hline & & 14. \\
\hline
\end{tabular}

15. Supplementary Notes

Prepared in cooperation with the U.S. Fish and Wildlife Service

16. Abstract (Limit: 200 words)

A hydrologic analysis of the proposed Badger-Beaver Creeks artificial-recharge project was made with the aid of three digital computer models: A canal-distribution model, a ground-water flow model, and a stream-aquifer model. Statistical summaries of probable diversions from the South Platte River based on a 27-year period of historical flows indicate that an average annual diversion of 96,000 acre-feet and a median annual diversion of 43,000 acre-feet would be available. Diversions would sustain water in ponds for waterfowl habitat for an average of about 5 months per year, with a maximum pond surface area of about 300 acres with the median diversions and a maximum pond surface area of about 1,250 acres at least one-half of the years with the historic diversions. If the annual diversion were 43,000 acre-feet, recharge to the two alluvial aquifers would raise water levels sufficiently to create flowing streams in the channels of Beaver and Badger Creeks while allowing an increase in current ground-water pumping. The only area of significant waterlogging would be along the proposed delivery canal on the west edge of Badger Creek valley. If the total water available were diverted, the aquifer system could not transmit the water fast enough to the irrigation areas to avoid considerable waterlogging in the recharge areas. The impact of the proposed project on the South Platte River basin would be minimal once the ground-water system attained steady-state conditions, but that may take decades with a uniform diversion of the 43,000 acre-feet annually.

17. Document Analysis a. Descriptors

Artificial recharge, Supplemental irrigation, Model studies, Wildlife habitats

b. Identifiers/Open-Ended Terms

Colorado, Morgan County, Beaver Creek, South Platte River basin

c. COSATI Field/Group

18. Availability Statement

No restriction on distribution

19. Security Class (This Report)

21. No. of Pages

20. Security Class (This Page)

22. Price 
HYDROLOGIC ANALYSIS OF THE PROPOSED BADGER-BEAVER CREEKS

ARTIFICIAL-RECHARGE PROJECT, MORGAN COUNTY, COLORADO

By Alan W. Burns

U.S. GEOLOGICAL SURVEY

Water-Resources Investigations $80-46$

Prepared in cooperation with the

U.S. Fish and Wildlife Service

Lakewood, Colorado

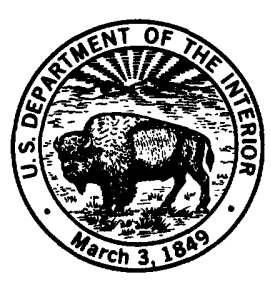

July 1980 
UNITED STATES DEPARTMENT OF THE INTERIOR

CECIL D. ANDRUS, Secretary

GEOLOGICAL SURVEY

H. William Menard, Director

For additional information write to:

District Chief

U.S. Geological Survey

Box 25046, Mail Stop 415

Denver Federal Center

Lakewood, c0 80225 
Metric conversions--

Abstract--

Introduction-

Proposed artificial-recharge project-

Purpose and scope-1

Availability of surface water-

Streamflow statistics-

Water rights-

Potential diversions-

Delivery and recharge of the diverted water-a

Distribution model-

Average pond conditions-

Model results-0

Ground-water system--

Hydrogeologic setting--

Development of ground-water models-

Data availabil ity---no

Calibration of the Beaver Creek valley model--

Calibration of the Badger Creek valley model---

Predicted conditions in Beaver Creek valley-

Predicted conditions in Badger Creek valley-

Total project impact--

Summary--

References--

Supplemental information-

Page

\section{ILLUSTRATIONS}

Figures 1-3. Maps showing location of:

1. Study area-- Proposed canal system-

2. Proposed canal system---

3. Gaging stations and diversion reservoirs-------4-6. Graphs showing:

4. Flow-duration curves for the South Platte River near Kersey and at Balzac-_-_.-.-.

5. Average winter (November through May) streamflow along the Kersey-Balzac reach of the South

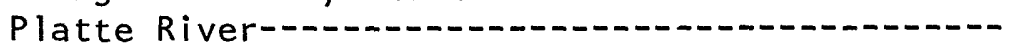

6. Flow-duration curve for the storable flow into the proposed Narrows Reservoir, October through June--.--

7. Schematic of canal-system layout--_-

8-13. Graphs showing:

8. Relationship of steady inflow into the ponds to the average steady-state pond surface area-----

9. Relationship of river diversion to water available for diversion into ponds--.-- 


\section{CONTENTS}

Figures 8-13. Graphs showing--Continued:

10. Relationship of steady inflow into the ponds and river diversions to the total steadystate pond surface area--

11. Monthly total pond surface areas for four canal-layout alternatives with 50-percent probability river diversions-_-

12. Monthly total pond surface areas for three canal-layout alternatives with 20-percent probability river diversions---..-.

13. Cumulative frequency curve of total pond surface area during April with 27 years of historically developed river diversions----.---

14. Map showing location of wells with long-term water-

level data, Beaver Creek valley-_-

15. Hydrographs of water levels for selected wells in

Beaver Creek valley-_...

16. Map showing location of wells with long-term water-

level data, Badger Creek valley-..-

17. Hydrographs of water levels for selected wells in

Badger Creek valley-_...

18-21. Maps showing altitude of water table:

18. Beaver Creek val ley, 1947- 39

19. Badger Creek valley, 1947-_. 40

20. Beaver Creek valley, 1978-_ 41

21. Badger Creek valley, 1978-_ 42

22-24. Graphs showing:

22. Relationship of annual precipitation to application rates from pumping in Beaver Creek valley-... 44

23. Cumulative irrigated acreage in Beaver and Badger Creek valleys-_ 45

24. Simulated historical pumping in Beaver Creek val ley--.-.-.

25-27. Maps showing altitude of water table computed by the mode 1:

25. Beaver Creek valley, preirrigation conditions---

26. Beaver Creek val ley, 1947-_...

27. Beaver Creek valley, 1978-_-

28-33. Hydrographs showing computed and recorded water levels

for:

28. Well 2-56-1DDD-- Well 2-56-13AAC-0-

29. Well 2-56-13AAC-

30. Well 2-56-24DD-- Well 1-56-10C--

31. Well 1-56-1DC-

32. Well 1-55-18BCD-_-

33. Well 1-55-31CDC- 1 - 


\section{CONTENTS}

Figure 34. Map showing change in 1978 water table in the absence

Page of local recharge or discharge as computed by the model for Badger Creek valley-..-..-

35. Map showing altitude of water table computed by the model using median-diversion recharge with estimated current pumping, Beaver Creek valley-che

36. Hydrographs of computed water levels for selected wells using median-diversion recharge with estimated current pumping, Beaver Creek valley-co

37. Graph showing simulated net stress to the aquifer using median- and historic-diversion recharge with estimated current pumping--

38. Graph showing average streamflow in Beaver Creek computed by the model using median- and historicdiversion recharge with estimated current pumping----

39-41. Hydrographs of water levels computed by the model using median- and historic-diversion recharge with estimated current pumping for:

39. Well 1-55-31CDC-

40. Well 2-56-24DD-_ Well 2-56-100D-

41. Well 2-56-1DDD-_te

42-44. Maps showing altitude of water table computed by the model using median-diversion recharge:

42. With computed maximum increased pumping,

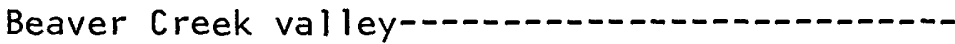

43. With estimated current pumping, Badger Creek valley---

44. With increased pumping, Badger Creek valley-----

\section{TABLES}

Table 1. Water rights of existing reservoirs-

2. Storable flows into the proposed Narrows Reservoir--

3. Distribution-model results of the average pond with an inflow of 1 cubic foot per second-.

4. Distribution-model results for various river diversions and no ponds--.-.

5. Distribution-model results for entire proposed canal system with 65 ponds and 50-percent probability river diversions-

6. Summary of distribution-model results for six canal-layout alternatives with 50-percent probability river diversions-

7. Distribution-model results for entire proposed canal system with 65 ponds and 20-percent probability river diversions-

8. Summary of distribution-model results for five canal-layout alternatives with 20-percent probability river diversions- 


\section{CONTENTS}

Table 9. Annual summary of distribution-model results for 27 years

of monthly, historically developed river diversions------

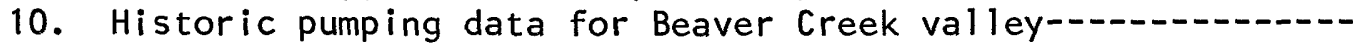

11. Simulated water budgets for Beaver Creek valley computed during calibration---.--

12. Steady-state water budgets computed by the model for five artificial-recharge configurations using median-diversion recharge with estimated current pumping, Beaver Creek

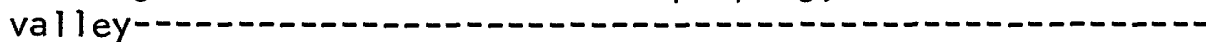

13. Monthly computed results from the twenty-seventh year of simulating median-diversion recharge with estimated current pumping, Beaver Creek valley-

14. Water budgets computed by the model for four artificialrecharge configurations using median-diversion recharge with computed increased pumping, Beaver Creek valley------

15. Water budget computed by the model using all canals, 65 ponds, median-diversion recharge, and maximum computed increased pumping, Beaver Creek valley----

16. Water budgets computed by the model for four artificial-

recharge configurations using median-diversion recharge
with estimated current pumping, Badger Creek valley---
17. Water budget computed by the model using all canals,

recharge configurations using median-diversion recharge
with estimated current pumping, Badger Creek valley-----
17. Water budget computed by the model using all canals, 65 ponds, median-diversion recharge, and increased pumping, Badger Creek valley-che

18. Water budget of changes in the South Platte River bas in due to the artificial-recharge project----

19. Altitude of water levels measured in the spring of 1978----

METRIC CONVERSIONS

Inch-pound units in this report may be expressed as metric units by use of the following conversion factors:

$\begin{array}{lc}\text { Multiply } & B y \\ \text { inch (in.) } & 25.40 \\ \text { foot (ft) } & 0.3048 \\ \text { mile (mi) } & 1.509 \\ \text { square foot }\left(\mathrm{ft}^{2}\right) & 0.09290 \\ \text { acre } & 0.4047 \\ \text { square mile }\left(\mathrm{mi}^{2}\right) & 2.590 \\ \text { cubic foot }\left(\mathrm{ft}^{3}\right) & 0.02832 \\ \text { acre-foot (acre- } \mathrm{ft}) & 0.001233 \\ \left.\text { cubic foot per second ( } \mathrm{ft}^{3} / \mathrm{s}\right) & 0.02832 \\ \text { foot per second (ft/s) } & 0.3048 \\ \text { foot per day (ft/d) } & 0.3048 \\ \text { gallon per minute per foot } & 17.90 \\ \text { [(gal/min)/ft] } & \end{array}$

MuZtiply

inch (in.)

foot $(f t)$

mile $(\mathrm{mi})$

square foot $\left(f t^{2}\right)$

acre

square mile $\left(m i^{2}\right)$

cubic foot $\left(\mathrm{ft}^{3}\right)$

acre-foot (acre-ft)

cubic foot per second $\left(\mathrm{ft}^{3} / \mathrm{s}\right)$

foot per second ( $\mathrm{ft} / \mathrm{s}$ )

foot per day $(\mathrm{ft} / \mathrm{d})$

$[(\mathrm{gal} / \mathrm{min}) / \mathrm{ft}$ ]
To obtain

millimeter

meter

ki lometer

square meter

hectare

square kilometer

cubic meter

cubic hectometer

cubic meter per second

meter per second

meter per day

square meter per day 


\title{
HYDROLOGIC ANALYSIS OF THE PROPOSED BADGER-BEAVER CREEKS
}

\author{
ARTIFICIAL-RECHARGE PROJECT, MORGAN COUNTY, COLORADO
}

By Alan W. Burns

\section{ABSTRACT}

A hydrologic analysis of the proposed Badger-Beaver Creeks artificialrecharge project was made with the aid of three digital computer models: A canal-distribution model, a ground-water flow model, and a stream-aquifer model. Statistical summaries of probable diversions from the South Platte River based on a 27-year record of flows indicate that an average annual diversion of 96,000 acre-feet and a median annual diversion of 43,000 acre-feet would be available. Diversions would sustain water in ponds for waterfowl habitat for an average of about 5 months per year, with a maximum pond surface area of about 300 acres with the median diversions and a maximum pond surface area of about 1,250 acres at least one-half of the years with the historic diversions. If the annual diversion were 43,000 acre-feet, recharge to the two alluvial aquifers would raise water levels sufficiently to create flowing streams in the channels of Badger and Beaver Creeks while allowing an increase in current ground-water pumping. The only area of significant waterlogging would be along the proposed delivery canal on the west edge of Badger Creek valley. If the total water available were diverted, the aquifer system could not transmit the water fast enough to the irrigation areas to avoid considerable waterlogging in the recharge areas. The hydrologic impact of the proposed project on the South Platte River basin would be minimal once the ground-water system attained steady-state conditions, but that may take decades with a uniform diversion of the 43,000 acre-feet annualiy.

\section{INTRODUCTION}

Badger and Beaver Creeks are small tributaries to the South Platte River in Morgan County, Colo. (fig. 1). The importance of these tributaries is not their streamflow--both are dry for most of their courses except during floods --but the alluvial aquifers adjacent to them. The two alluvial aquifers underlie valleys that are 1 to $5 \mathrm{mi}$ wide and provide ground water for irrigation in areas where surface water from the South Platte River is not supplied by gravity flow. Code $(1943$, p. 41 ) reports, "Pumping in this valley (Beaver Creek) dates back to about 1910. There was a small steady growth up through 1936, but in the 4 years following, the number of plants increased more than twofold, or to 53, south of Brush in 1940. Electric power became available 

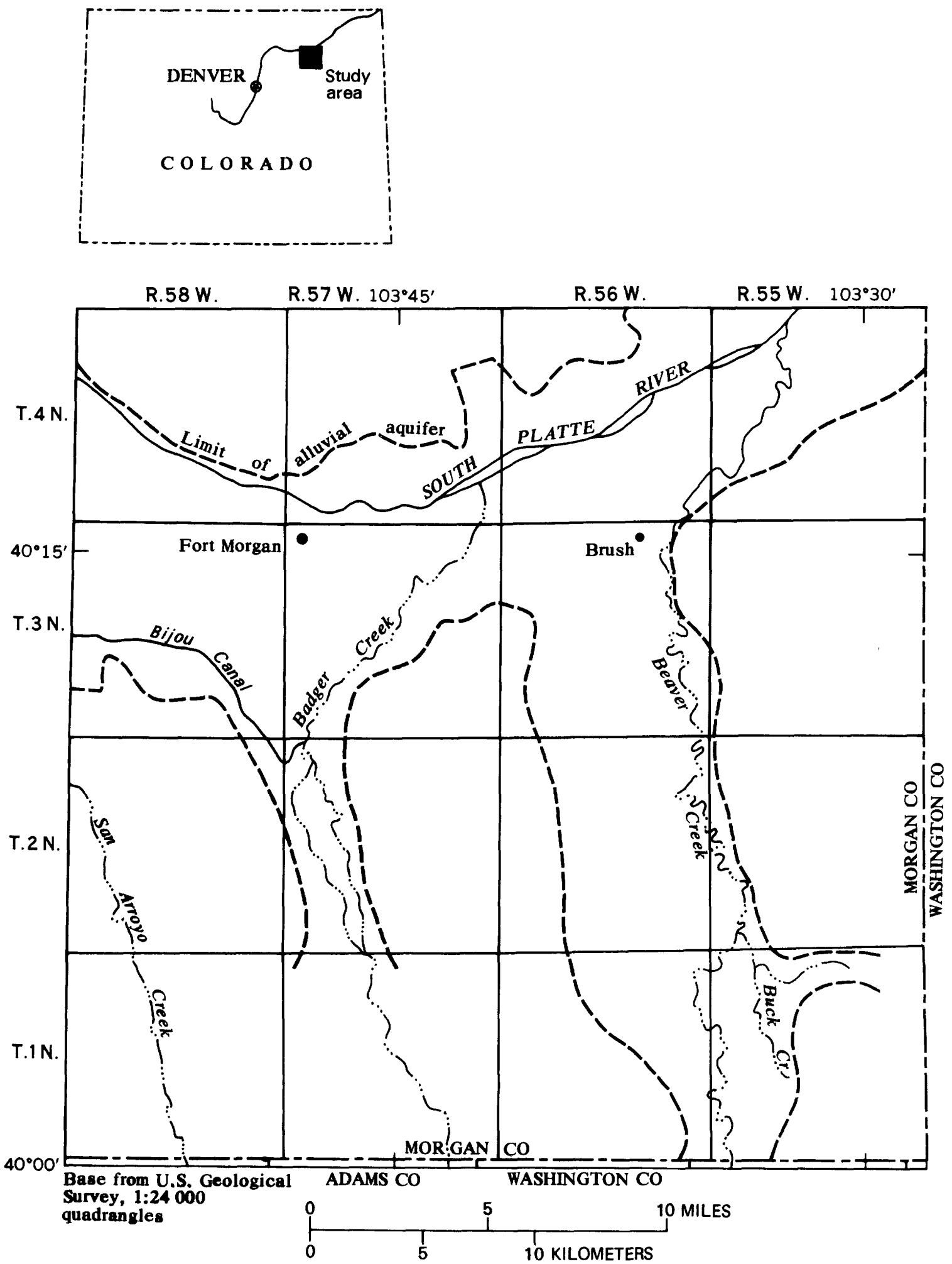

Figure 1.- Location of study area. 
in 1939." Pumping continued to increase, according to Bjorklund and Brown (1957), who reported that 109 wells were pumped in 1946 and 138 wells were pumped in 1950. The increased pumping began creating drawdown problems as early as 1950. Bjorklund and Brown (1957, p. 50) reported, "The decline of the water table is more critical in the Beaver Creek valley than in any other part of the South Platte River valley project area . . ." Pumping apparently continued to increase until drawdowns caused abandonment of numerous wells and withdrawal of land from irrigation.

\section{Proposed Artificial-Recharge Project}

In April 1976, the Badger and Beaver Water Conservancy District was formed under the provisions of Article 45, Title 37, Colorado Revised Statutes, 1973. The purpose of this conservancy district was to promote a project to artificially recharge the two alluvial aquifers in an attempt to again achieve the historical pumping rates and return lands to their previous irrigated conditions. Although no formal engineering designs have been developed, a preliminary plan has been developed. According to the plan, water would be diverted from the South Platte River at the headgate of the existing Bijou Canal just west of Canton, Colo., in Weld County (fig. 2). Water would flow through the Bijou Canal to about the mouth of San Arroyo Creek south of Griffin, Colo., in Morgan County, where it would be diverted into a new canal to be constructed. This new canal would cross the channel of Badger Creek at about the section line between Tps. 1 and $2 \mathrm{~N}$., R. $57 \mathrm{~W}$., where some water would be released down the channel of Badger Creek. About $2.5 \mathrm{mi}$ downstream, water in Badger Creek would be diverted to another canal to be constructed east of the creek. This canal would trend northward along the edge of the sand hills and terminate about $2 \mathrm{mi}$ north of the section line between Tps. 2 and 3 N., R. 57 W.

Water not diverted into Badger Creek would be pumped into a lined canal leading to the channel of Beaver Creek near the southern Morgan County line, where the water would be released into the channel of Beaver Creek. About $1 \mathrm{mi}$ downstream, part of the water would be diverted into a new canal to be constructed west of the creek. This canal would trend northward through the sand hills and terminate about $2.5 \mathrm{mi}$ south of Brush (fig. 2). In addition, another canal may be constructed to carry water farther east where it could be released to the channels of Buck Creek and an unnamed draw (fig. 2).

It is also proposed to create numerous ponds throughout this rechargedistribution system by either installing check dams along the canals and channels or by creating turnouts to the many natural depressions, particularly in the sand hills. These proposed ponds primarily would enhance the environment relative to wildlife and waterfowl. Water would seep from the canals, stream channels, and ponds, and infiltrate the underlying aquifers. The desired result of this infiltration would be to recharge the aquifers sufficiently to accommodate increased ground-water pumping during the irrigation season. 


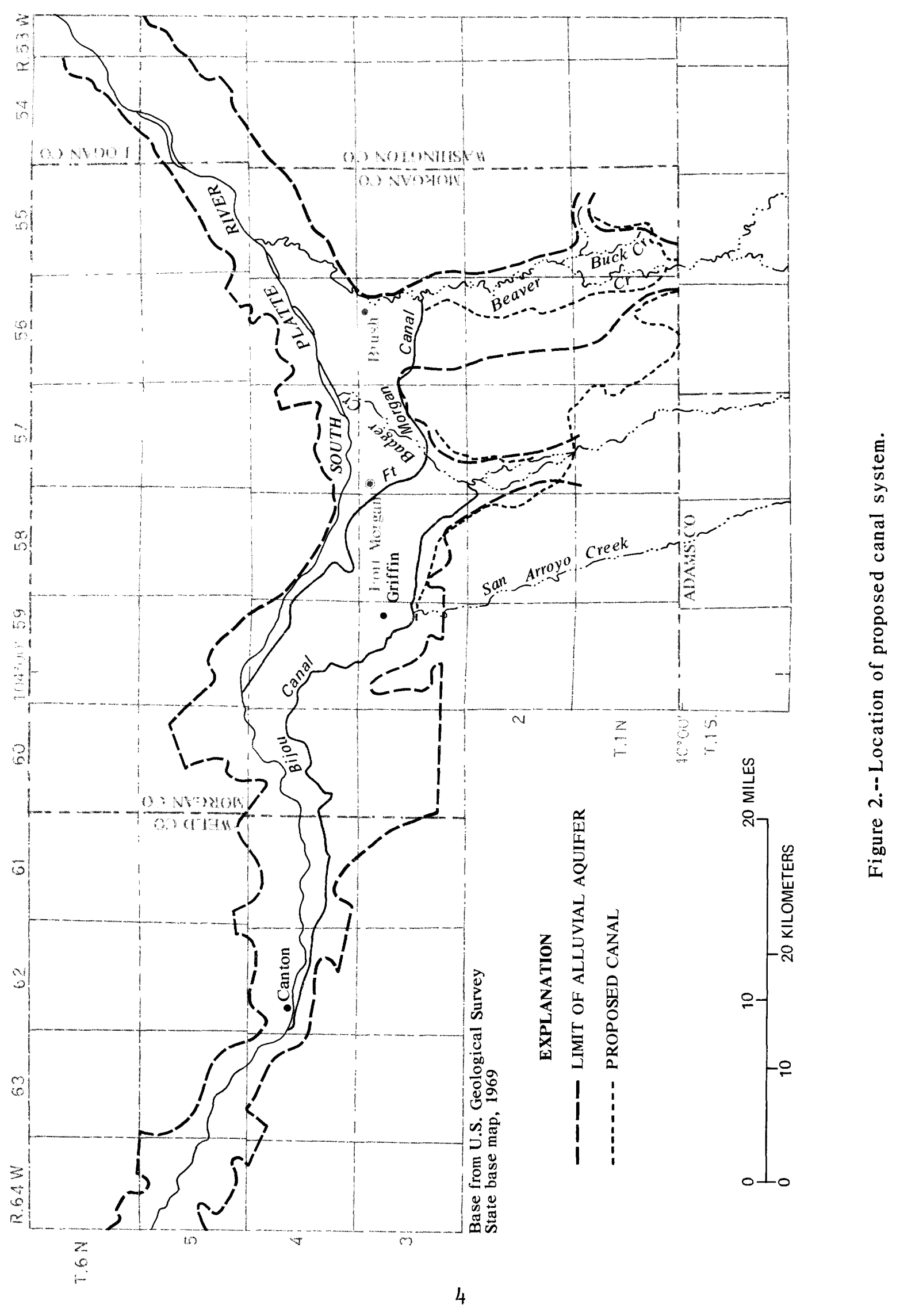


In a filing in the District Court in and for Water Division No. 1, State of Colorado, the conservancy district has requested a water right of 240,000 acre-ft annually to be made senior in right to filing 366 for the proposed Narrows Reservoir and also has asked for an alternative point of diversion for the $355.025 \mathrm{ft}^{3} / \mathrm{s}$ decreed rights of existing wells to the headgate of Bijou Ditch. On the basis of these water-right filings and the typical flows in the South Platte River, the conservancy district proposes to divert about 90,000 acre-ft per year into the canal system.

\section{Purpose and Scope}

In February 1978, the U.S. Fish and Wildlife Service entered into a Memorandum of Agreement with the Badger and Beaver Water Conservancy District. Under the terms of this agreement, the U.S. Fish and Wildlife Service would finance a hydrologic analysis of the proposed project because of the potential benefits to wildlife that could accrue through development of wetlands from ground-water augmentation projects. It was believed that artificial recharge could become widely used in the South Platte River basin of northeastern Colorado. The U.S. Fish and Wildlife Service determined that through this study it would gain a better understanding about the direct and indirect impacts of artificial recharge on fish and wildlife.

In March 1978, the U.S. Fish and Wildlife Service agreed to fund an 18month study to be conducted by the U.S. Geological Survey of the hydrologic aspects of the proposed artificial-recharge project. The study had four primary objectives: (1) The availability of water for diversion from the South Platte River; (2) the delivery and recharge of the diverted water; (3) the effects of the artificial recharge on the ground-water system; and (4) the total hydrologic impact of the proposed project on the South Platte River basin. The study was to consider only the general hydrologic aspects of the proposed project and was not intended to consider any site-specific hydraulic conditions, engineering-design problems, or economic considerations.

At the request of the U.S. Fish and Wildlife Service, a meeting was held on March 16, 1979, at which the U.S. Geological Survey presented preliminary results of the study to representatives of the U.S. Fish and Wildlife Service and the Badger and Beaver Water Conservancy District. On May 23, 1979, the U.S. Fish and Wildlife Service notified the Badger and Beaver Water Conservancy District that it could not participate in the wildlife-management part of the recharge plan because preliminary results of the study indicated that the project would significantly deplete flows in the South Platte River. According to the U.S. Fish and Wildlife Service, such depletion could have adverse effects on habitat for whooping cranes or other migratory birds along the Platte River in Nebraska. However, all parties agreed that the results of the study should be published. 
The South Platte River is the principal source of surface water for irrigation in the plains of northeastern Colorado. Between 1850 and 1900, numerous irrigation canal and ditch companies formed and constructed headgates along the river to divert water to the fields and to off-channel reservoirs. Leakage from these canals and reservoirs plus applications of water on the land in excess of consumptive use sustains a huge aquifer within the alluvium adjacent to the river. Discharge from this aquifer has transformed the South Platte River into a gaining stream throughout most of its course.

\section{Streamflow Statistics}

Data to determine the streamflow available for diversion have been collected at the gaging stations in the Kersey-Balzac reach of the river by either the U.S. Geological Survey or the Colorado Department of Natural Resources, Division of Water Resources, Office of the State Engineer. These stations (fig. 3) and dates for which data are available are: Kersey (1905present); Sublette (1927-55); Weldona (1952-present); and Balzac (1916present).

The streamflow of the South Platte River is quite variable--within the year, from year to year, and from site to site. The flow-duration curves for Kersey and Balzac (fig. 4) show this temporal variability, and the different placement and shape of the two curves indicate the spatial variability. In spite of the fact that the South Platte River is an effluent stream (a gaining stream due to ground-water inflow), the many diversions cause the streamflow to decrease downstream through this reach. From 1927 through 1955 the average flows were: Kersey, $625 \mathrm{ft}^{3} / \mathrm{s}$; Sublette, $336 \mathrm{ft}^{3} / \mathrm{s}$; and Balzac, $301 \mathrm{ft}^{3} / \mathrm{s}$. From 1952 through 1976 the average flows were: Kersey, $847 \mathrm{ft}^{3} / \mathrm{s}$; Weldona, $572 \mathrm{ft}^{3} / \mathrm{s}$; and Balzac, $439 \mathrm{ft}^{3} / \mathrm{s}$.

\section{Water Rights}

To gain legal access to water for diversion during the nonirrigation season, the project must conform with the water rights of existing reservoirs. The reservoirs in the Kersey-Balzac reach of the river with senior water rights are Bijou No. 2, Empire, Jackson, North Sterling, Prewitt, and Riverside (fig. 3). On the basis of records provided by the State Engineer's Office (Walter Knudsen, written commun., 1975), the apparent rights of these reservoirs are listed in table 1 along with the basin rank, which is a priority numbering system.

\section{Potential Diversions}

The data used for determining the potential diversions for the proposed project came from an analysis by the U.S. Bureau of Reclamation (Roger Wiedlemann, written commun., 1976). The Bureau computed the streamflow that 


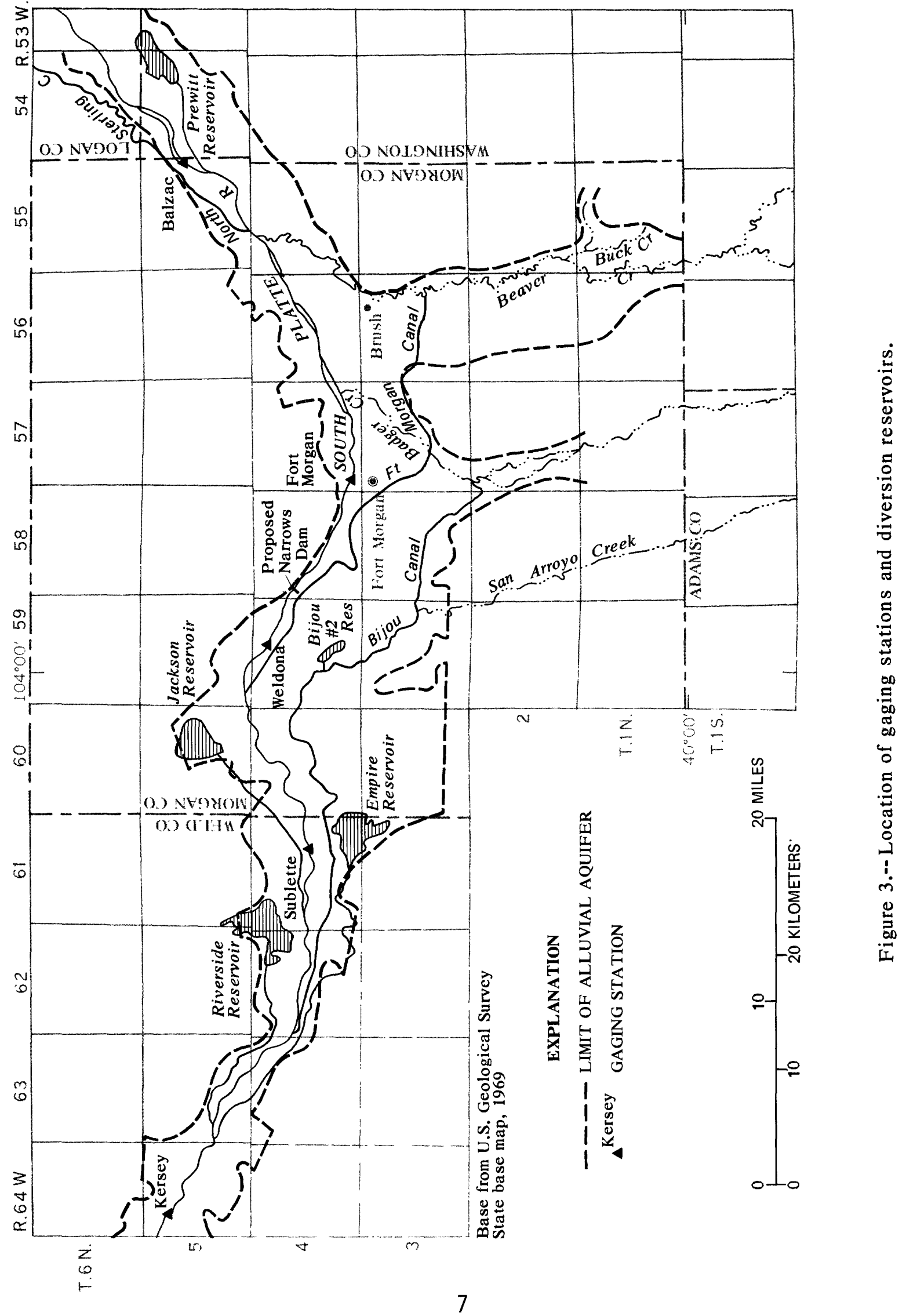






Figure 4.-- Flow-duration curves for the South Platte River near Kersey and at Balzac. 
Table 1.--Water rights of existing reservoirs

\begin{tabular}{|c|c|c|}
\hline Reservoir & $\begin{array}{c}\text { Annual volume } \\
\text { (acre-feet) }\end{array}$ & Basin rank ${ }^{l}$ \\
\hline $\begin{array}{l}\text { Bijou Reservoir No. } \\
\text { Jackson Lake } \\
\text { Riverside Reservoir } \\
\text { Jackson Lake } \\
\text { Empire Reservoir }\end{array}$ & $\begin{array}{r}9,183 \\
30,992 \\
16,070 \\
4,637 \\
37,710\end{array}$ & $\begin{array}{l}1,047 \\
1,364 \\
1,384 \\
1,485 \\
1,580\end{array}$ \\
\hline $\begin{array}{l}\text { Riverside Reservoir } \\
\text { North Sterling Reservoir } \\
\text { Prewitt Reservoir } \\
\text { Riverside Reservoir } \\
\text { North Sterling Reservoir }\end{array}$ & $\begin{array}{r}41,437 \\
69,446 \\
32,300 \\
7,501 \\
11,954\end{array}$ & $\begin{array}{l}1,725 \\
1,762 \\
1,841 \\
1,863 \\
1,985\end{array}$ \\
\hline $\begin{array}{l}\text { Empire Reservoir } \\
\text { Riverside Reservoir } \\
\text { Jackson Lake } \\
\text { Prewitt Reservoir }\end{array}$ & $\begin{array}{r}37,709 \\
56,325 \\
8,270 \\
34,960\end{array}$ & $\begin{array}{l}2,490 \\
2,490 \\
2,490 \\
2,490\end{array}$ \\
\hline
\end{tabular}

${ }^{1}$ A ranking system used by the Colorado Department of Natural Resources, Division of Water Resources, Office of the State Engineer, in which the smaller numbers have higher priority.

could be stored in the proposed Narrows Reservoir. This computed flow (referred to as storable flow for purposes of this report) is considered to be representative of the available legal diversion for the proposed project, even though the site of the proposed Narrows Dam is downstream from the headgate of Bijou Canal. This analysis would be invalid if the Narrows Reservoir were constructed and the water right there remained senior to that of the proposed project.

The average winter flow (November through May) and the average storable flow for those same 7 months, when there is typically no irrigation, for the Kersey-Balzac reach of the river is shown in figure 5. These plots were based on 1947-61 data obtained from a U.S. Bureau of Reclamation study (1965). The flow-duration curve of the storable flow from October through June, when diversion for storage would be allowed, for 1947 to 1974 is shown in figure 6 . The large variability is indicated by the monthly distributions of the storable flow for these same data in table 2 .

The divertible flow for this proposed project would be the storable flows except for the fact that the capacity of the Bijou Canal will prevent the diversion of the higher flows. The reported capacity of the Bijou Canal is 30,000 acre-ft per month and, thus, any monthly storable flow that exceeds 30,000 acre-ft is limited to that value. Because of the high variability of the monthly flows (table 2), the effects of this limitation are quite dramatic. The average storable flow from 0ctober through June for the 1947-74 period is 217,000 acre-ft but the average divertible flow is only 96,000 acre-ft. Because the average flow occurs only about 30 percent of the time, the median (50-percent) storable flow is used as the divertible flow for most of this study. 


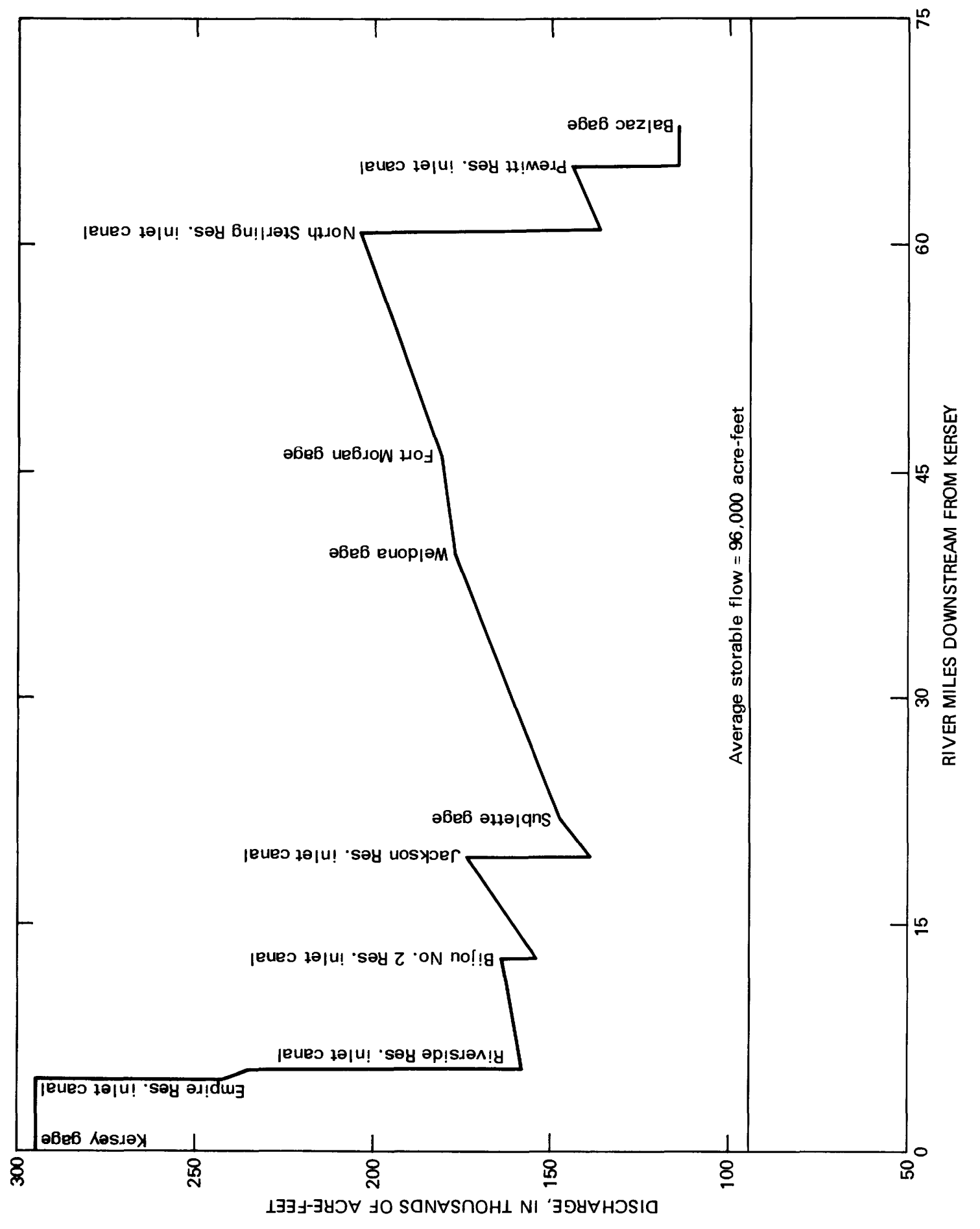

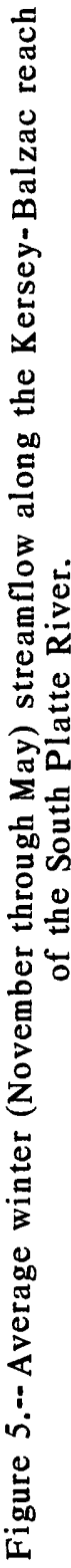






告 
Table 2.--Storable flows into the proposed Narrows Reservoir

[Computed from U.S. Bureau of Reclamation analysis for 1947-1974]

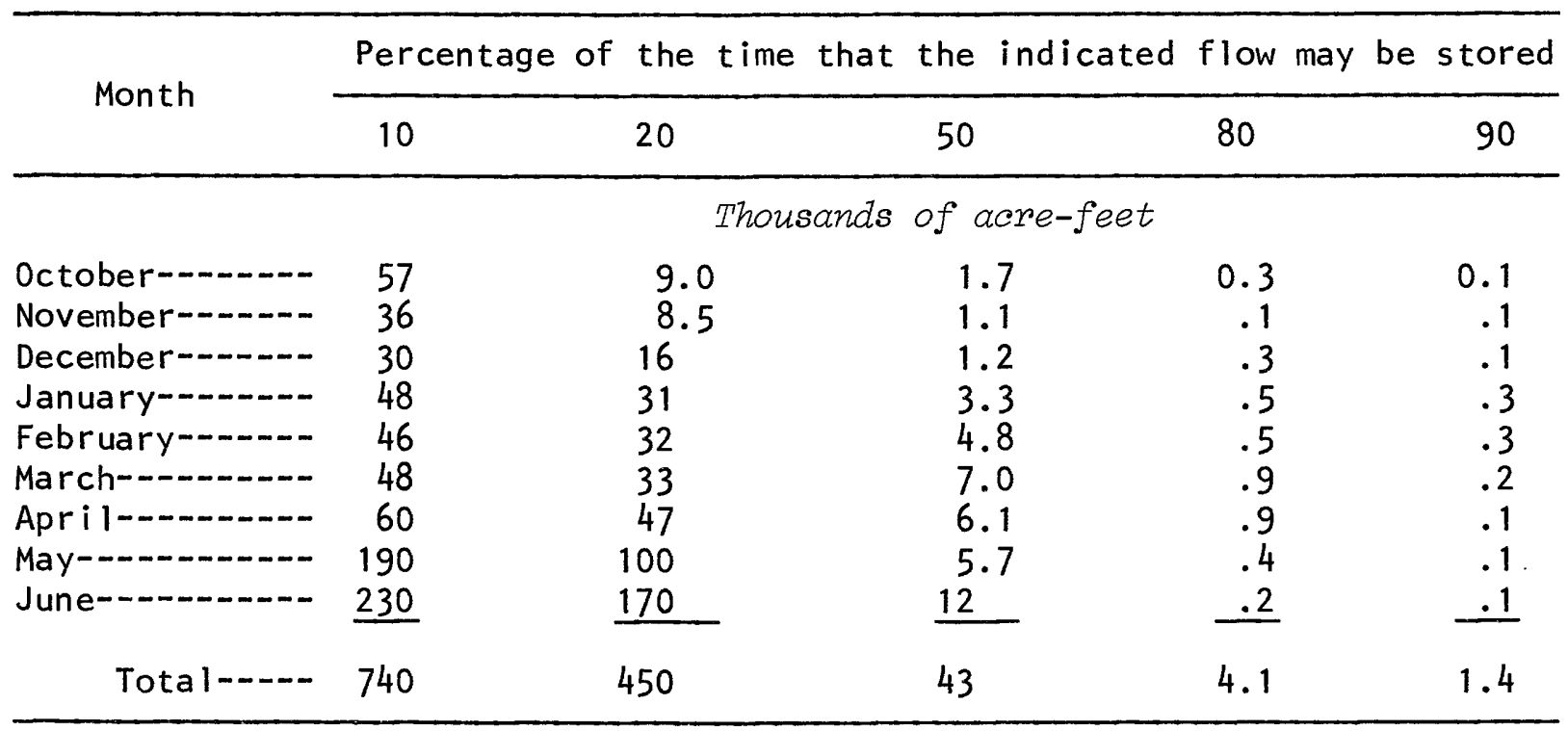

\section{DELIVERY AND RECHARGE OF THE DIVERTED WATER}

The proposed project would divert water through much of the existing Bijou Canal before diverting it into new canals to be built as part of the project. Some of these canals would lead to depressions in the adjacent sand hills where ponds would be formed. The purpose of these canals and ponds is to allow water to recharge to the adjacent and underlying aquifers. James Pugh (Superintendent, Bijou Irrigation System, written commun., 1978) estimates seepage along the downstream length of the Bijou Canal to be 12 to 15 percent of the flow. According to Mr. Pugh, and a local retired farmer who was interviewed, a ditch was constructed about 1900 in the vicinity of part of the proposed system west of Badger Creek valley. This ditch was abandoned due to large seepage rates.

During a field trip to the area June 12-14, 1978, several observations of flow were made. On June 13, water was released from Bijou Canal into Badger Creek in sec. 6, T. 2 N., R. $57 \mathrm{~W}$. The duration of the release was less than 2 days and the quantity was unknown; the flow in the canal on the morning of June 14 was measured at $8 \mathrm{ft}^{3} / \mathrm{s}$. The entire release seeped from the channel within a $0.5-\mathrm{mi}$ reach below the release point. During the same trip, water from the Fort Morgan Canal also was being released into Badger Creek in sec. 21, T. $3 \mathrm{~N} .$, R. $57 \mathrm{~W}$. Discharge measurements indicated $12 \mathrm{ft}^{3} / \mathrm{s}$ in Badger Creek about $1 \mathrm{mi}$ downstream and only $4 \mathrm{ft}^{3} / \mathrm{s}, 2.5 \mathrm{mi}$ downstream from the release point. The creek channel was completely dry $1 \mathrm{mi}$ farther downstream. Previous releases of unknown quantities from the Fort Morgan Canal had caused seepage losses from Beaver Creek for a distance of about $2 \mathrm{mi}$ downstream from the release point. 


\section{Distribution Model}

A digital computer model was developed for this study to simulate the routing of the diversions from the river throughout the canal and pond system, and to compute the seepage losses. There are four basic components to the model: (1) Routing the flow along the channels; (2) proportioning the flow at the diversion points; (3) simulating the pond conditions; and (4) computing the seepage. The time interval used in the model is 1 month. That is the time interval of the diversion data and also seems to be the shortest convenient time interval for all the water to move through the entire canal system at low flow.

The canal system is described by reaches which connect node points. The nodes are identified by their latitude, longitude, and altitude of land surface. These data were digitized from maps of the preliminary canal layout provided by Thomas Norton (Norton, Underwood, and Lamb Engineering Consultants, written commun., 1978) (fig. 2). The model uses 982 nodes to describe the 225-mi network (fig. 7).

Flow routing is a simple conservation of mass with the only cause of depletion in a reach being seepage,

$$
Q_{\text {out }}=Q_{\text {in }^{-S}}
$$

where $Q_{\text {out }}$ is the discharge leaving the reach, in cubic feet per second;

$Q_{\text {in }}$ is the discharge entering the reach, in cubic feet per second; and

$S$ is the seepage lost within the reach, in cubic feet per second.

Possible losses due to evaporation or transpiration are considered small and were ignored. An important feature of the routing component of the model was the computation of depth of the water in canals. The depth is needed for computing time of travel and seepage. The depth is computed by two different techniques, depending on which part of the canal system is being analyzed. In the existing part of the canal, there are so many check gates and dams for the purpose of diverting water to farm laterals that the only useful technique was a stage-discharge relationship. Based on discharge measurements made by D. R. Minges (U.S. Geological Survey, written commun., 1978) on the Fort Morgan Canal and Lower Platte and Beaver Canal, the general logarithmic function computed is:

$$
h=0.106 Q^{0.640}
$$

where $h$ is depth of the water in the canal, in feet; and

$Q$ is the discharge in the canal, in cubic feet per second. 


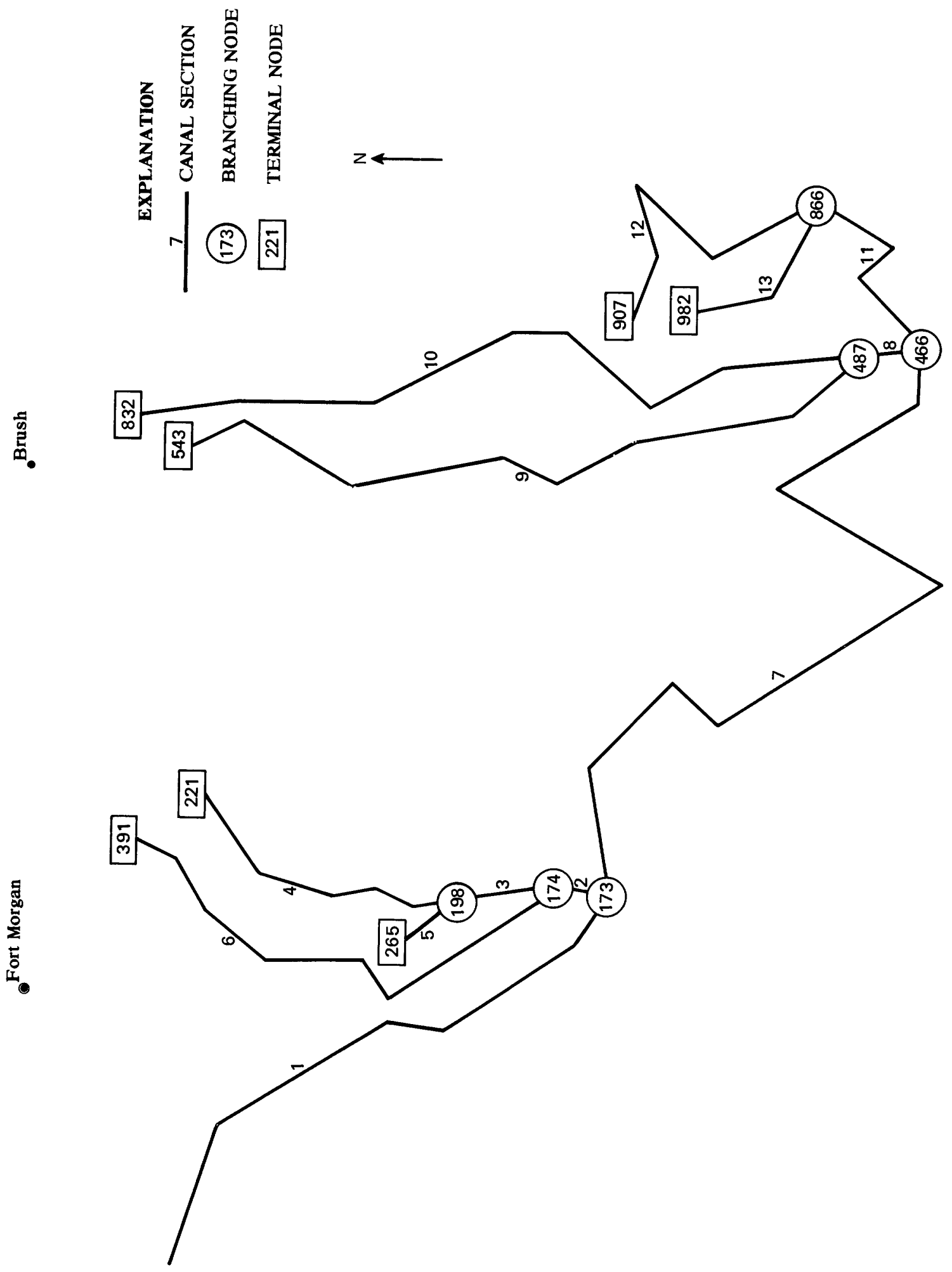

ت 
Because the widths, slopes, and numbers and types of check gates are quite similar for most of the canals in this part of the South Platte River valley, the above function is believed to be representative. For the rest of the canal system, Manning's equation (Chow, 1959) was iteratively solved until the computed discharge equaled the routed discharge. This is an iterative process because the hydraulic radius is a function of wetted perimeter which is a function of depth:

$$
\begin{gathered}
Q=\frac{1.486}{n} \cdot A_{c} \cdot R^{2 / 3} \cdot S_{0}^{1 / 2}, \\
A_{c}=h \cdot W, \text { and } \\
R=A_{c} / P=\frac{h W}{2 h+W} \text { (for rectangular channel), }
\end{gathered}
$$

where $Q$ is the discharge of the canal, in cubic feet per second;

$n$ is the Manning's coefficient;

$A_{C}$ is the cross-sectional area of water in the canal, in square feet;

$R$ is the hydraulic radius, in feet;

$S_{O}$ is the dimensionless channel slope;

$h$ is the depth of water in the channel, in feet;

$W$ is the average width of water in the channel, in feet; and

$P$ is the wetted perimeter, in feet.

The flows were distributed through the system by trying to make the diversions at branching nodes (fig. 7) such that water just reached the terminal node (fig. 7). If there was less water than potential leakage, then water was diverted to each section on the basis of section number and potential seepage rate. The water was diverted to each section until all the water was used; and the last sections would receive less than their potential, or none, if the excess water was gone. If there was more water available than the combined potential leakage rates, the extra water was apportioned evenly to all the ponds. Proportioning the flow at points of diversion was a trial-anderror routine. Because seepage is partly a function of the hydraulic head in the canal, whenever the diversion through a section of the canal system changes, the seepage also may change. The technique used to distribute water at a branching node (fig. 7) was to divert exactly the amount of water needed so that the seepage in the last reach causes the flow at the terminal node of the section to be zero. This was an iterative process whereby all of the water was initially diverted into one section. The amount of outflow at the end of the section was then subtracted from the first diversion, to determine the estimated second iteration diversion. Because the seepage decreased with the new decreased diversion, there still was outflow from the section and the process was repeated. A schematic of the number of branching nodes that had to be repeatedly solved is shown in figure 7 . 
Computing the monthly pond conditions was based on mass balance of the volume stored. The average volume for the month was computed by:

$$
V_{\text {AVG }}=\left(V_{\text {BEGIN }}+V_{\text {END }}\right) / 2 \text {, }
$$

where $V_{A V G}$ is the average storage, in cubic feet;

$V_{\text {BEGIN }}$ is the storage at the beginning of the month, in cubic feet; and $V_{\text {END }}$ is the storage at the end of the month, in cubic feet.

However,

$$
V_{\text {END }}=V_{B E G I N}{ }^{+Q} I N^{-E-S} \text {, }
$$

where $Q_{I N}$ is the inflow, in cubic feet per month;

$E$ is the evaporation, in cubic feet per month; and

$S$ is the seepage, in cubic feet per month.

Because evaporation is a function of surface area and seepage is a function of depth, these values are actually functions of the average monthly volume. Thus, there is an iterative process of estimating the average volume; computing evaporation and seepage from that average volume; solving equation 7 for $V_{\text {END; }}$ and then comparing the average volume computed with equation 6 with the initial estimate. The initial estimate can be systematically adjusted and the above step repeated several times until the computed and estimated average volumes compare within an acceptable level of error.

Computations of pond surface area, depth, and shoreline perimeter were of interest to wildlife-habitat specialists. Because no specific pond sites have been chosen, a typical shape and slope of the potential ponds was determined by evaluating depressions in the sand hills using topographic maps. This analysis led to the following formulations:

and

$$
\frac{r}{d}=50 \text {, }
$$

$$
\bar{d}=0.4 d \text {, }
$$

where $r$ is the radius of an assumed pond, in feet;

$d$ is the maximum depth, in feet; and

$\bar{d}$ is the average depth, in feet.

Using the assumed circular surface area, then

and

$$
A=\pi r^{2}=(50 d)^{2} \pi=15,625 \bar{d}^{2},
$$

$$
V=\bar{d} A,
$$

where $V$ is the volume in storage, in cubic feet; and

$A$ is the surface area, in square feet. 
By examining the topographic maps, it was estimated that the average shoreline would be about 140 percent of the minimum perimeter that would be computed assuming a perfect circle. Therefore,

$$
P_{p}=(1.4) \cdot 2 \cdot \pi \cdot p=2.8 \pi 50 d=350 \pi \bar{d}
$$

where $P_{p}$ is the length of shoreline, in feet.

The computation of seepage from a canal is discussed in the literature. Many of these papers--Morel-Seytoux (1964), Bouwer (1965), Garg and Chawla (1970), Hunt (1972), and Abiodun (1973), for example--consider solutions dealing with varied geometries of the channel, variable hydraulic conductivity between channel sediments and the aquifer, and various depths to the water table below the canal. Other papers--Schiff (1953), Robinson and Rohwer (1957), Bouwer, Myers, and Rice (1962), and Worstell (1976)--consider the more practical aspects of measuring and estimating canal seepage and the effects of velocity and hydraulic head on seepage. Without considering the theoretical aspects, it generally appears that in the study area where the water level is typically far below the land surface, the primary considerations for estimating seepage are hydraulic conductivity of the soils and the hydraulic head in the canal. As discussed earlier, the hydraulic head in the canal is computed as part of the routing model. The hydraulic conductivity of the soils was determined from infiltration rates for soil types (Terstriep and Stall, 1974) and a soil type was assigned to each node from the soil survey of Morgan County (U.S. Department of Agriculture, 1968). Thus, the seepage is computed as:

$$
S=A \cdot I_{\alpha} \cdot\left(k_{1}+k_{2} \cdot h\right)
$$

where $S$ is the seepage, in cubic feet per second;

$A$ is the surface area, in square feet;

$I_{a}$ is the multiplication factor for the infiltration rate for a particular soil type;

$k_{1}$ is the intercept of a linear relationship between infiltration and hydraulic head, in feet per second;

$k_{2}$ is the slope of a linear relationship between infiltration and hydraulic head, in feet per second per foot of head change; and

$h$ is the depth of water, in feet.

The $I_{\alpha}$ factor was zero for the 1 ined part of the canal and ranged from 1 to 10 for seven additional soil types identified. The $k_{1}$ value used was about $0.05 \mathrm{ft} / \mathrm{d}$ and the $k_{2}$ value was about $0.01 \mathrm{ft} / \mathrm{d}$. The $k_{1}$ parameter was adjusted somewhat during calibration so that the computed seepage matched values expected for this region based on other studies. For instance, in a stream-aquifer model of the entire South Platte River valley, R. T. Hurr and A. W. Burns (U.S. Geological Survey, written commun., 1977) used a value of $1 \mathrm{ft}^{3} / \mathrm{s}$ per mi of canal. Bittinger and others (1979) interviewed personnel of several ditch companies whose ditches are immediately downstream of this 
study area and arrived at a consensus average seepage loss of about 25 percent of the diversion. Parshall (1922) measured seepage losses of $7.8 \mathrm{ft}^{3} / \mathrm{s}$ in a $9-\mathrm{mi}$ reach $\left(0.9 \mathrm{ft}^{3} / \mathrm{s}\right.$ per $\left.\mathrm{mi}\right)$ of Jackson Reservoir inlet canal and of $19.3 \mathrm{ft}^{3} / \mathrm{s}$ in a $19.7-\mathrm{mi}$ reach $\left(1 \mathrm{ft}^{3} / \mathrm{s}\right.$ per $\mathrm{mi}$ ) of the Empire Reservoir inlet. In 1967, D. R. Minges (U.S. Geological Survey, written commun., 1978) measured several of the reservoir inlet canals in the South Platte River basin and calculated seepage losses ranging from 0.2 to $2.8 \mathrm{ft}^{3} / \mathrm{s} \mathrm{per} \mathrm{mi.} \mathrm{Code}$ (1945) reported canal losses in the nearby Prospect Valley of $0.6 \mathrm{ft}^{3} / \mathrm{s}$ per mi. Worstell (1976) reviewed and summarized 765 seepage tests made in the western United States and found that seepage rates normally ranged from $0.1 \mathrm{ft} / \mathrm{d}$ to $2 \mathrm{ft} / \mathrm{d}$, which for a typical canal width of $40 \mathrm{ft}$ would range from 0.2 to $5 \mathrm{ft}^{3} / \mathrm{s}$ per $\mathrm{mi}$.

Pond seepage was also computed using equation 13. Although there are no pond-seepage data for the project area, pond-seepage data from other areas were available and were the primary adjustment factors for the $k_{2}$ parameter. Skinner (1963) computed changes in infiltration rates of about $0.25 \mathrm{ft} / \mathrm{d}$ per $\mathrm{ft}$ for 0lds Reservoir in Prospect Valley. Taylor (1975) computed values from 0.04 to $2 \mathrm{ft} / \mathrm{d}$ per $\mathrm{ft}$ in several ponds near Fountain, Colo. Emmons (1977) computed average rates of change of $0.7 \mathrm{ft} / \mathrm{d}$ per $\mathrm{ft}, 4 \mathrm{ft} / \mathrm{d}$ per $\mathrm{ft}$, and $4 \mathrm{ft} / \mathrm{d}$ per $\mathrm{ft}$ at three sites in El Paso County, Colo. Prill (1977) computed values ranging from 0.7 to $2.2 \mathrm{ft} / \mathrm{d}$ per $\mathrm{ft}$ for a pond in western Kansas.

\section{Average Pond Conditions}

An important aspect of the proposed project is the wildlife-environment enhancement due to the ponds. Estimates of the diversions to ponds and their size and number are necessary parameters for assessing that part of the project. Because no site-specific engineering has been done, typical pond geometries were computed and it was assumed that ponds would be placed uniformly along canals located in the sand hills.

Several model-simulation runs were made to evaluate the effects of various pond diversions. Each simulation was made over several months with a particular inflow diversion until the ponds reached a steady-state condition. An example of the results of one such simulation is shown in table 3 . After making several of these simulations, figure 8 was drawn to illustrate the diversion into a pond necessary to maintain it at a certain surface area. Steady-state seepage is nearly equal to the inflow, with the evaporation being much smaller than the seepage. A problem with the transient analysis that needs to be resolved for any additional studies involves the oscillations in all values other than inflow in table 3. Although not considered critical for this analysis, the use of smaller time steps or some predictor-corrector technique would result in oscillations with reduced magnitudes--the ideal being no oscillations. 
Table 3.--Distribution-model results of the average pond with an inflow of 1 cubic foot per second

\begin{tabular}{|c|c|c|c|c|c|}
\hline Month & $\begin{array}{l}\text { Inflow } \\
\text { (cubic feet } \\
\text { per second) }\end{array}$ & $\begin{array}{l}\text { Mean } \\
\text { depth } \\
\text { (feet) }\end{array}$ & $\begin{array}{l}\text { Surface } \\
\text { area } \\
\text { (acres) }\end{array}$ & $\begin{array}{l}\text { Shore- } \\
\text { line } \\
\text { (miles) }\end{array}$ & $\begin{array}{c}\text { Seepage } \\
\text { (cubic feet } \\
\text { per second) }\end{array}$ \\
\hline $\begin{array}{l}1--- \\
2--- \\
3---\end{array}$ & $\begin{array}{l}1.00 \\
1.00 \\
1.00\end{array}$ & $\begin{array}{l}1.74 \\
2.01 \\
1.90\end{array}$ & $\begin{array}{l}3.45 \\
4.62 \\
4.18\end{array}$ & $\begin{array}{r}0.36 \\
.42 \\
.40\end{array}$ & $\begin{array}{r}0.78 \\
1.06 \\
.93\end{array}$ \\
\hline $\begin{array}{l}4--- \\
5--- \\
6---\end{array}$ & $\begin{array}{l}1.00 \\
1.00 \\
1.00\end{array}$ & $\begin{array}{l}1.97 \\
1.95 \\
1.95\end{array}$ & $\begin{array}{l}4.48 \\
4.39 \\
4.39\end{array}$ & $\begin{array}{l}.41 \\
.41 \\
.41\end{array}$ & $\begin{array}{r}1.02 \\
.99 \\
.99\end{array}$ \\
\hline $\begin{array}{l}7--- \\
8--- \\
9---\end{array}$ & $\begin{array}{l}1.00 \\
1.00 \\
1.00\end{array}$ & $\begin{array}{l}1.94 \\
1.94 \\
1.94\end{array}$ & $\begin{array}{l}4.32 \\
4.34 \\
4.32\end{array}$ & $\begin{array}{l}.40 \\
.40 \\
.40\end{array}$ & $\begin{array}{l}.98 \\
.98 \\
.97\end{array}$ \\
\hline $\begin{array}{l}10--- \\
11---\end{array}$ & 1.00 & 1.94 & $\begin{array}{l}4.32 \\
\text { teady-sta }\end{array}$ & .40 & $\begin{array}{r}.97 \\
--------\end{array}$ \\
\hline
\end{tabular}

The distribution model was also run with various inflow conditions to identify the available flow for diversions into the ponds. Different river diversions were routed through the system without any ponds being simulated. The excess outflow from the system that would occur is shown in table 4. This outflow is an indication of the quantity of water that would be available to be diverted into ponds. A linear regression relating the river diversion to the excess outflow (fig. 9) was computed to be:

$$
P S=-82.5+0.913 D,
$$

where $P S$ is the potential supply to ponds, in cubic feet per second; and

$D$ is the river diversion, in cubic feet per second.

The regression coefficients were placed in the model along with the number of ponds to be simulated. Based on the monthly diversion, the model computed the amount of water to be diverted to each pond. 





Table 4.--Distribution-model results for various river diversions and no ponds

\begin{tabular}{cccccc}
\hline $\begin{array}{c}\text { River } \\
\text { diversion } \\
\text { (cubic feet } \\
\text { per second) }\end{array}$ & $\begin{array}{c}\text { Seepage from } \\
\text { section } 1^{1} \\
\text { (cubic feet } \\
\text { per second) }\end{array}$ & $\begin{array}{c}\text { Seepage from } \\
\text { section } \\
\text { (cubic feet } \\
\text { per second } \\
\text { per mile) }\end{array}$ & $\begin{array}{c}\text { Total } \\
\text { seepage } \\
\text { (cubic feet } \\
\text { per second) }\end{array}$ & $\begin{array}{c}\text { Travel- } \\
\text { time } \\
\text { (days) }\end{array}$ & $\begin{array}{c}\text { Excess } \\
\text { outflow } \\
\text { (cubic feet } \\
\text { per second) }\end{array}$ \\
\hline 10 & 10 & $(2)$ & 10 & 31.8 & 0 \\
25 & 25 & $(2)$ & 25 & 33.1 & 0 \\
50 & 43 & 0.9 & 50 & 36.2 & 0 \\
100 & 49 & 1.0 & 91 & 11.2 & 9 \\
150 & 54 & 1.1 & 97 & 10.4 & 53 \\
200 & 58 & 1.2 & 102 & 10.0 & 98 \\
300 & 66 & 1.4 & 111 & 9.6 & 189 \\
400 & 72 & 1.5 & 119 & 9.4 & 281 \\
500 & 78 & 1.7 & 126 & 9.2 & 374 \\
\hline
\end{tabular}

${ }^{1}$ See figure 7 for location.

${ }^{2}$ Length is unknown because water did not reach the end of section 1 .

${ }^{3}$ Flow did not get through the entire system.

Combining the results of the average surface area per pond (fig. 8) and the available supply for pond diversion (fig. 9) yields the total pond surface area that could be maintained from a given river diversion (fig. 10). These relationships were computed by dividing the potential supply to ponds (equation 14) by the average inflow to the ponds in order to obtain the number of ponds. The total surface area is computed by multiplying the number of ponds times the average pond surface area (fig. 8). The total number of ponds in the model was limited to 75 , and, thus, the curves in figure 10 have limits on the left side of the graph. 







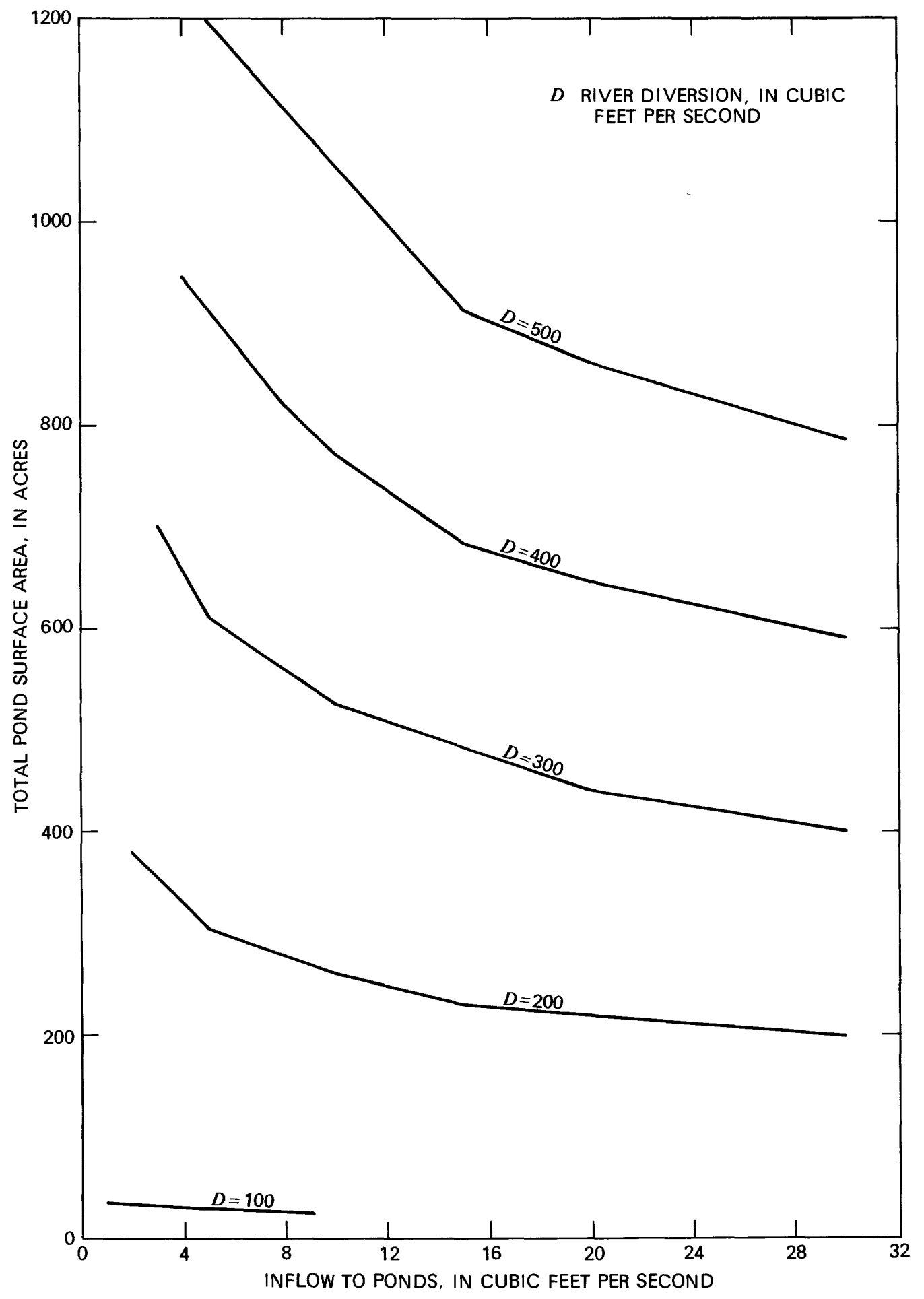

Figure 10.-- Relationship of steady inflow into the ponds and river diversions to the total steady-state pond surface area. 
The distribution model was used to evaluate the proposed project for various river flow conditions and combinations of proposed canals. Two assumptions made in the model that are simplifications which need to be considered in any engineering analysis are: (1) The ditch capacity is $500 \mathrm{ft}^{3} / \mathrm{s}$ for its entire course and (2) water can be diverted and delivered all winter. A typical example of model results is shown in table 5 . The simulation computing these results used 1 year of inflow data representative of the 50-percent divertible flows (table 2) and assumed the entire proposed canal system was used with 65 ponds along the two canals that would be constructed through the sand hills. These results show that an average of $59.3 \mathrm{ft}^{3} / \mathrm{s}$ would be diverted during the year and most of that water would be lost as seepage. However, not all of the seepage would be located geographically to aquifers in the alluvial valleys. The column labeled "Beneficial seepage" accounts for all the seepage except for that occurring in section 1 of the canal system (fig. 7). Most of section 1 is the existing part of the Bijou Canal and overlies the alluvium of the South Platte River valley. Thus, seepage in this part of the canal system will recharge the South Platte River alluvial aquifer and contribute eventually to the return flows of the river, but not to the alluvial aquifers of Badger and Beaver Creek valleys. The simulation also indicated that ponds would contain water for only 5 of the 12 months, with a maximum total surface area of 304 acres.

Table 5.--Distribution-model results for entire proposed canal system with 65 ponds and 50-percent probability river diversions

\begin{tabular}{cccccc}
\hline Month & $\begin{array}{c}\text { Diversion } \\
\text { inflow } \\
\text { (cubic feet } \\
\text { per second) }\end{array}$ & $\begin{array}{c}\text { Total } \\
\text { seepage } \\
\text { (cubic feet } \\
\text { per second) }\end{array}$ & $\begin{array}{c}\text { Beneficial } \\
\text { seepage } \\
\text { (cubic feet } \\
\text { per second) }\end{array}$ & $\begin{array}{c}\text { Pond } \\
\text { seepage } \\
\text { (cubic feet second) }\end{array}$ & $\begin{array}{c}\text { Total pond } \\
\text { surface } \\
\text { area } \\
\text { (acres) }\end{array}$ \\
\hline October----- & 28.2 & 28.2 & 0 & 0 & 0 \\
November---- & 18.2 & 18.2 & 0 & 0 & 0 \\
December---- & 19.9 & 19.9 & 0 & 0 & 0 \\
January----- & 54.7 & 54.7 & 10.76 & 0 & 0 \\
February---- & 79.6 & 79.6 & 32.44 & 0 & 0 \\
March----- & 116.0 & 112.31 & 61.25 & 19.72 & 89.5 \\
Apri1------ & 101.0 & 104.01 & 54.48 & 13.01 & 65.8 \\
May----- & 94.5 & 93.61 & 44.77 & 3.41 & 17.3 \\
June------ & 199.0 & 177.17 & 118.79 & 77.36 & 304.0 \\
July------- & 0 & 20.35 & 20.35 & 20.35 & 145.3 \\
August---- & 0 & 0 & 0 & 0 & 0 \\
September--- & 0 & 0 & 0 & 0 & 0 \\
Average--- & 59.3 & 59.0 & 28.57 & 11.2 & 51.8 \\
\hline
\end{tabular}


A summary of six model simulations comparing different geographical layouts of the proposed canal system is presented in table 6 . The alternative "Recharge canals only" assumed that no water would be released to the channels of Badger and Beaver Creeks and only those canals which are planned to go through the sand hills would be constructed. The alternative "Recharge canals plus extension" assumed that the canal leading to Buck Creek in Beaver creek valley also would be constructed. From the viewpoint of beneficial seepage, none of the alternatives has any distinct advantage over another. Pond surface area can be increased by eliminating diversions to the creek channels if this situation creates a better wildlife environment. The monthly distribution of the total pond surface area for four canal-layout alternatives is shown in figure 11 .

Table 6.--Summary of distribution-model results

for six canal-layout alternatives

with 50-percent probability river diversions

\begin{tabular}{|c|c|c|c|c|}
\hline Alternative & $\begin{array}{l}\text { Beneficial } \\
\text { seepage } \\
\text { (cubic feet } \\
\text { per second) }\end{array}$ & $\begin{array}{c}\text { Pond } \\
\text { seepage } \\
\text { (cubic feet } \\
\text { per second) }\end{array}$ & $\begin{array}{l}\text { Duration } \\
\text { of ponds } \\
\text { (months) }\end{array}$ & $\begin{array}{c}\text { Maximum monthly } \\
\text { total pond } \\
\text { surface area } \\
\text { (acres) }\end{array}$ \\
\hline $\begin{array}{l}\text { Entire canal system } \\
\text { with } 7 \text { ponds }\end{array}$ & 28.6 & 11.2 & 6 & 201 \\
\hline $\begin{array}{l}\text { Entire canal system } \\
\text { with } 65 \text { ponds--- }\end{array}$ & 28.6 & 11.2 & 5 & 304 \\
\hline $\begin{array}{l}\text { Beaver Creek valley only } \\
\quad(53 \text { ponds) }\end{array}$ & 28.5 & 14.7 & 6 & 339 \\
\hline $\begin{array}{l}\text { Badger Creek valley only } \\
(22 \text { ponds) }\end{array}$ & 28.4 & 23.3 & 6 & 345 \\
\hline $\begin{array}{l}\text { Recharge canals only } \\
\quad(65 \text { ponds) }\end{array}$ & 28.2 & 23.7 & 6 & 400 \\
\hline $\begin{array}{l}\text { Recharge canals plus } \\
\text { extension ( } 65 \text { ponds) -- }\end{array}$ & 28.4 & 22.2 & 6 & 392 \\
\hline
\end{tabular}



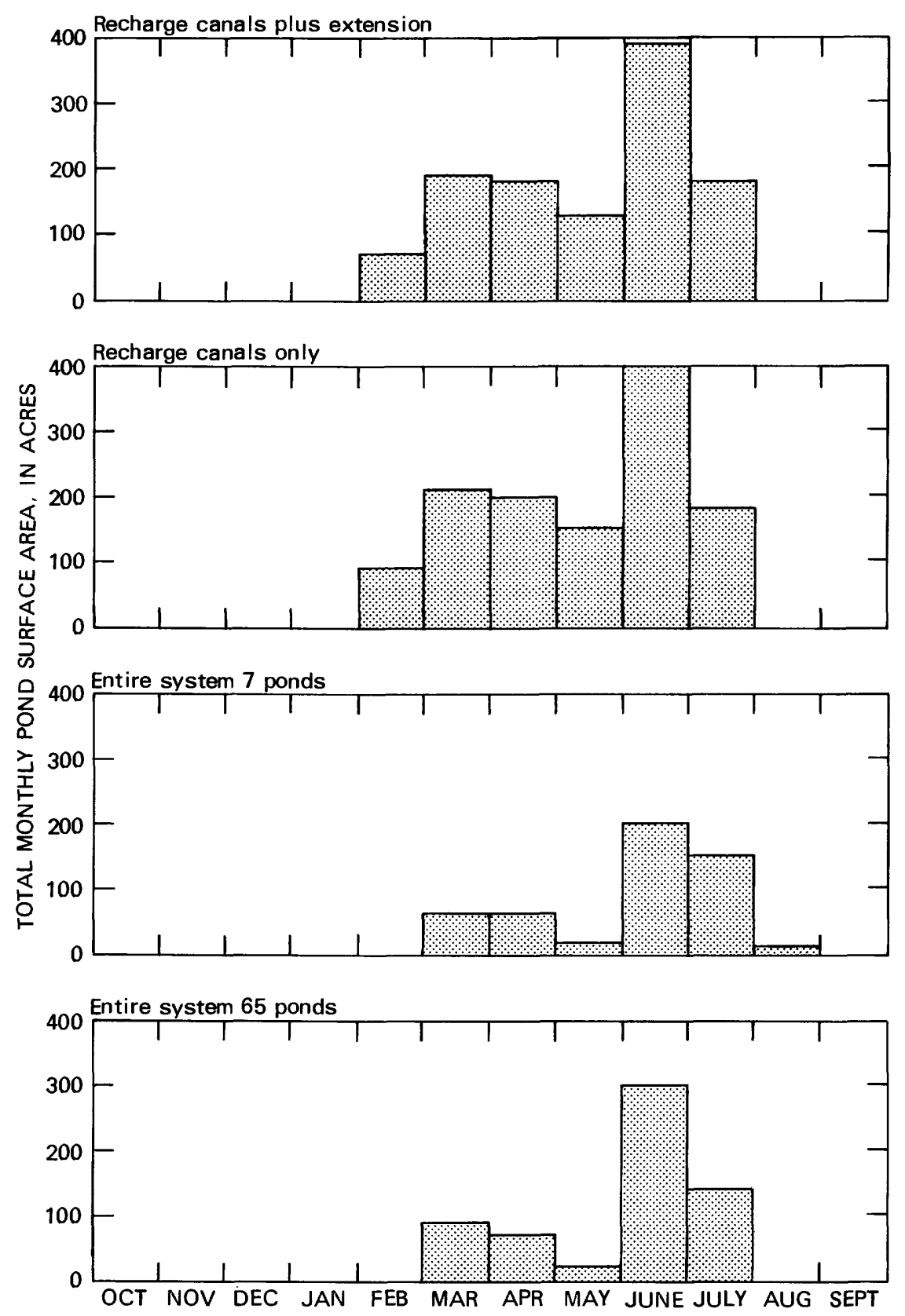

Figure 11.-- Monthly total pond surface areas for four canal-layout alternatives with 50 -percent probability river diversions. 
Another set of simulations was made with the larger river diversions of 20-percent probability (table 2). Example model results for the same canallayout alternative as used to create table 5 are shown in table 7 . The summary of five of the canal-layout alternatives for the larger river diversions is shown in table 8. The monthly distribution of the total pond surface area for three of these alternatives is shown in figure 12.

Table 7.--Distribution-model results for entire proposed canal system with 65 ponds and 20-percent probability river diversions

\begin{tabular}{|c|c|c|c|c|c|}
\hline Month & $\begin{array}{l}\text { Diversion } \\
\text { inflow } \\
\text { (cubic feet } \\
\text { per second) }\end{array}$ & $\begin{array}{c}\text { Total } \\
\text { seepage } \\
\text { (cubic feet } \\
\text { per second) }\end{array}$ & $\begin{array}{c}\text { Beneficial } \\
\text { seepage } \\
\text { (cubic feet } \\
\text { per second) }\end{array}$ & $\begin{array}{c}\text { Pond } \\
\text { seepage } \\
\text { (cubic feet } \\
\text { per second) }\end{array}$ & $\begin{array}{l}\text { Total pond } \\
\text { surface } \\
\text { area } \\
\text { (acres) }\end{array}$ \\
\hline $\begin{array}{l}\text { October---.- } \\
\text { November---- } \\
\text { December-.-- }\end{array}$ & $\begin{array}{l}149 \\
141 \\
265\end{array}$ & $\begin{array}{l}138.60 \\
146.55 \\
230.10\end{array}$ & $\begin{array}{r}84.44 \\
93.11 \\
166.71\end{array}$ & $\begin{array}{r}43.13 \\
51.78 \\
124.54\end{array}$ & $\begin{array}{l}182 \\
215 \\
460\end{array}$ \\
\hline $\begin{array}{l}\text { January----- } \\
\text { February---- } \\
\text { March------ }\end{array}$ & $\begin{array}{l}500 \\
500 \\
500\end{array}$ & $\begin{array}{l}442.61 \\
514.62 \\
487.71\end{array}$ & $\begin{array}{l}364.15 \\
436.16 \\
409.25\end{array}$ & $\begin{array}{l}319.39 \\
391.39 \\
364.49\end{array}$ & $\begin{array}{l}1,015 \\
1,203 \\
1,138\end{array}$ \\
\hline 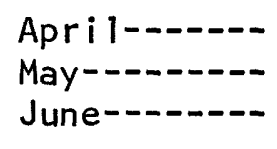 & $\begin{array}{l}500 \\
500 \\
500\end{array}$ & $\begin{array}{l}493.79 \\
490.85 \\
491.03\end{array}$ & $\begin{array}{l}415.33 \\
412.39 \\
412.57\end{array}$ & $\begin{array}{l}370.56 \\
367.62 \\
367.81\end{array}$ & $\begin{array}{l}1,152 \\
1,145 \\
1,145\end{array}$ \\
\hline $\begin{array}{l}\text { July-------- } \\
\text { August------ } \\
\text { September--- }\end{array}$ & $\begin{array}{l}0 \\
0 \\
0\end{array}$ & $\begin{array}{l}75.57 \\
0 \\
0\end{array}$ & $\begin{array}{l}75.57 \\
0 \\
0\end{array}$ & $\begin{array}{l}75.57 \\
0 \\
0\end{array}$ & $\begin{array}{r}431 \\
0 \\
0\end{array}$ \\
\hline Average--- & 296 & 293 & 239 & 206 & 674 \\
\hline
\end{tabular}



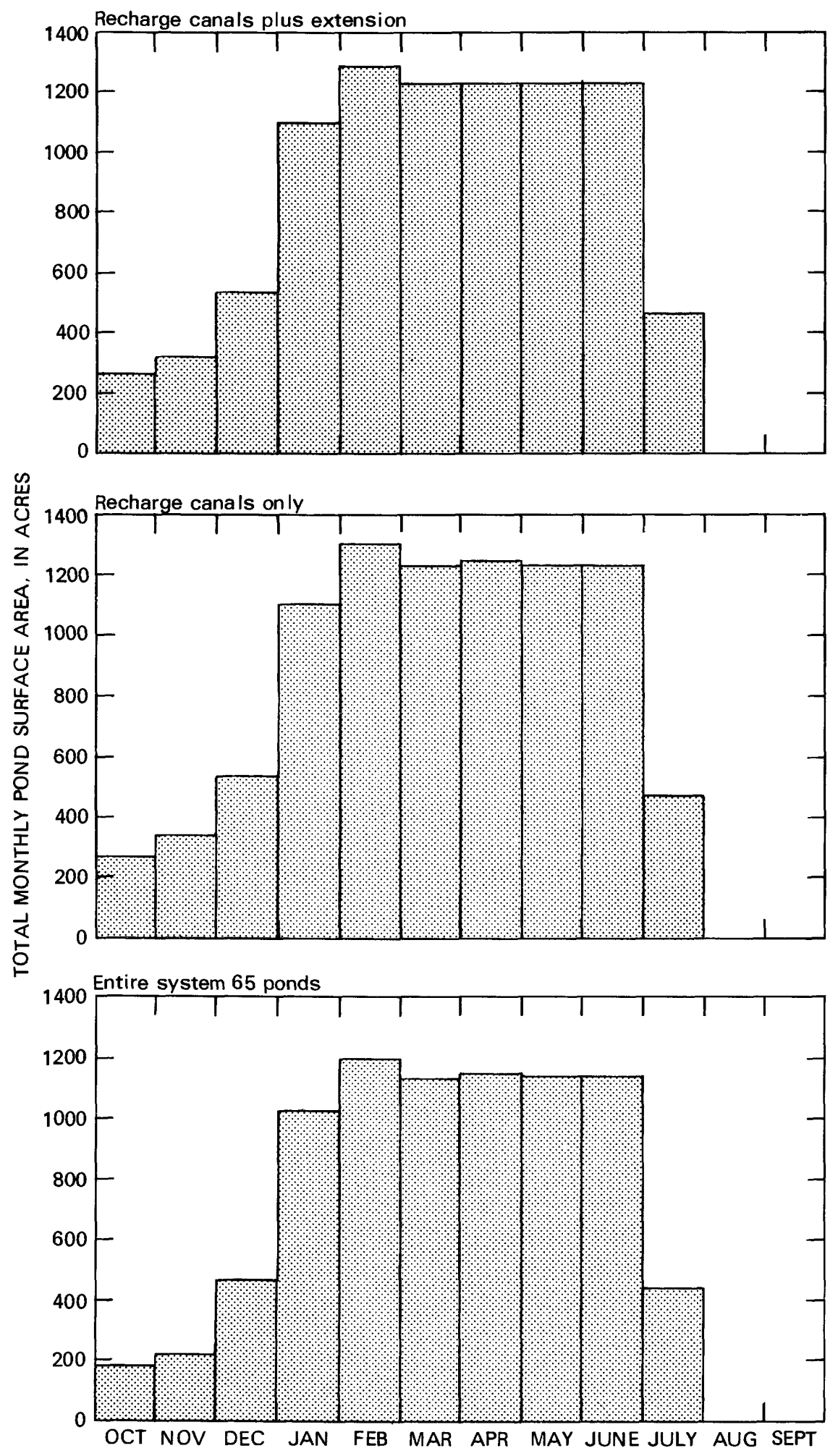

Figure 12.-- Monthly total pond surface areas for three canal-1ayout alternatives with 20 -percent probability river diversions. 
Table 8.--Summary of distribution-model results

for five canal-layout alternatives

with 20-percent probability river diversions

\begin{tabular}{lcccc}
\hline Alternative & $\begin{array}{c}\text { Beneficial } \\
\text { seepage } \\
\text { (cubic feet } \\
\text { per second) }\end{array}$ & $\begin{array}{c}\text { Pond } \\
\text { seepage } \\
\text { (cubic feet } \\
\text { per second) }\end{array}$ & $\begin{array}{c}\text { Duration } \\
\text { of ponds } \\
\text { (months) }\end{array}$ & $\begin{array}{c}\text { Maximum monthly } \\
\text { total pond } \\
\text { surface area } \\
\text { (acres) }\end{array}$ \\
\hline $\begin{array}{l}\text { Entire canal system } \\
\text { with 65 ponds--- }\end{array}$ & 239 & 206 & 10 & 1,203 \\
$\begin{array}{c}\text { Beaver Creek valley } \\
\text { only--- }\end{array}$ & 241 & 214 & 11 & 1,257 \\
$\begin{array}{c}\text { Badger Creek valley } \\
\text { only--- }\end{array}$ & 237 & 233 & 10 & 1,109 \\
$\begin{array}{c}\text { Recharge canals only--- } \\
\begin{array}{l}\text { Recharge canals plus } \\
\text { extension--- }\end{array}\end{array} 240$ & 232 & 10 & 1,292 \\
\hline
\end{tabular}

To compare the results from the simulations using river diversions of certain probabilities (20 percent and 50 percent have been shown), one final simulation was made with 27 years of historically developed data. The river diversions for this simulation are the estimated monthly divertible flows for 1947 through 1974. These are the same storable flows used to compute the frequencies shown in table 2, limited when necessary by the capacity of Bijou Canal. An annual summary of the model results by water years is presented in table 9. Although not listed in this table, the historical diversions compare quite closely and would be slightly larger than the total seepage shown in table 9. Of particular interest relative to the potential waterfowl habitat is the pond acreage during April. The frequency curve for the pond surface area during April for the 27-year period is shown in figure 13. 
Table 9.--Annual summary of distribution-model results for 27 years of monthly, historically developed river diversions

\begin{tabular}{|c|c|c|c|c|c|}
\hline Year & $\begin{array}{c}\text { Average } \\
\text { seepage } \\
\text { (cubic feet } \\
\text { per second) }\end{array}$ & $\begin{array}{l}\text { Average } \\
\text { pond area } \\
\text { (acres) }\end{array}$ & $\begin{array}{l}\text { Maximum } \\
\text { pond area } \\
\text { (acres) }\end{array}$ & $\begin{array}{l}\text { Duration } \\
\text { of ponds } \\
\text { (months) }\end{array}$ & $\begin{array}{c}\text { April } \\
\text { pond area } \\
\text { (acres) }\end{array}$ \\
\hline $\begin{array}{l}1-- \\
2-- \\
3-- \\
4-- \\
5--\end{array}$ & $\begin{array}{r}221.0 \\
111.6 \\
44.0 \\
28.5 \\
168.1\end{array}$ & $\begin{array}{r}552.2 \\
286.6 \\
79.0 \\
30.7 \\
417.8\end{array}$ & $\begin{array}{r}1,292 \\
966 \\
483 \\
150 \\
1,274\end{array}$ & $\begin{array}{r}10 \\
6 \\
4 \\
4 \\
6\end{array}$ & $\begin{array}{r}1,216 \\
0 \\
376 \\
133 \\
778\end{array}$ \\
\hline $\begin{array}{c}6-- \\
7-- \\
8-- \\
9-- \\
10--\end{array}$ & $\begin{array}{r}33.0 \\
8.1 \\
21.2 \\
5.2 \\
103.1\end{array}$ & $\begin{array}{c}43.3 \\
0 \\
21.9 \\
0 \\
249.4\end{array}$ & $\begin{array}{r}334 \\
0 \\
141 \\
0 \\
1,319\end{array}$ & $\begin{array}{l}3 \\
0 \\
3 \\
0 \\
7\end{array}$ & $\begin{array}{r}334 \\
0 \\
0 \\
0 \\
0\end{array}$ \\
\hline $\begin{array}{l}11-- \\
12-- \\
13-- \\
14-- \\
15--\end{array}$ & $\begin{array}{r}264.0 \\
111.3 \\
125.0 \\
91.1 \\
324.6\end{array}$ & $\begin{array}{l}658.7 \\
276.8 \\
350.6 \\
186.4 \\
837.0\end{array}$ & $\begin{array}{l}1,269 \\
1,279 \\
1,249 \\
1,317 \\
1,320\end{array}$ & $\begin{array}{r}8 \\
4 \\
7 \\
4 \\
10\end{array}$ & $\begin{array}{r}1,269 \\
1,080 \\
1,249 \\
64 \\
1,153\end{array}$ \\
\hline $\begin{array}{l}16-- \\
17-- \\
18-- \\
19-- \\
20--\end{array}$ & $\begin{array}{r}60.7 \\
9.6 \\
43.1 \\
203.1 \\
61.4\end{array}$ & $\begin{array}{r}152.0 \\
2.9 \\
127.3 \\
487.4 \\
136.7\end{array}$ & $\begin{array}{r}888 \\
29 \\
939 \\
1,320 \\
954\end{array}$ & $\begin{array}{l}4 \\
2 \\
2 \\
8 \\
3\end{array}$ & $\begin{array}{r}345 \\
29 \\
0 \\
0 \\
0\end{array}$ \\
\hline $\begin{array}{l}21-- \\
22-- \\
23-- \\
24-- \\
25--\end{array}$ & $\begin{array}{r}14.3 \\
94.2 \\
328.8 \\
336.7 \\
144.4\end{array}$ & $\begin{array}{c}0 \\
235.2 \\
832.7 \\
857.9 \\
345.3\end{array}$ & $\begin{array}{r}0 \\
1,313 \\
1,321 \\
1,253 \\
823\end{array}$ & $\begin{array}{r}0 \\
4 \\
10 \\
9 \\
8\end{array}$ & $\begin{array}{r}0 \\
119 \\
1,156 \\
1,235 \\
279\end{array}$ \\
\hline $\begin{array}{l}26-- \\
27--\end{array}$ & $\begin{array}{l}278.5 \\
314.6\end{array}$ & $\begin{array}{l}699.0 \\
790.4\end{array}$ & $\begin{array}{l}1,289 \\
1,320\end{array}$ & $\begin{array}{l}10 \\
10\end{array}$ & $\begin{array}{l}1,240 \\
1,236\end{array}$ \\
\hline $\begin{array}{l}\text { Average } \\
\text { of the } \\
27 \text { years--- }\end{array}$ & 131.5 & 320.6 & ${ }^{1} 1,249$ & 5.4 & ${ }^{\mathrm{I}} 279$ \\
\hline
\end{tabular}

${ }^{1}$ Median rather than average. 


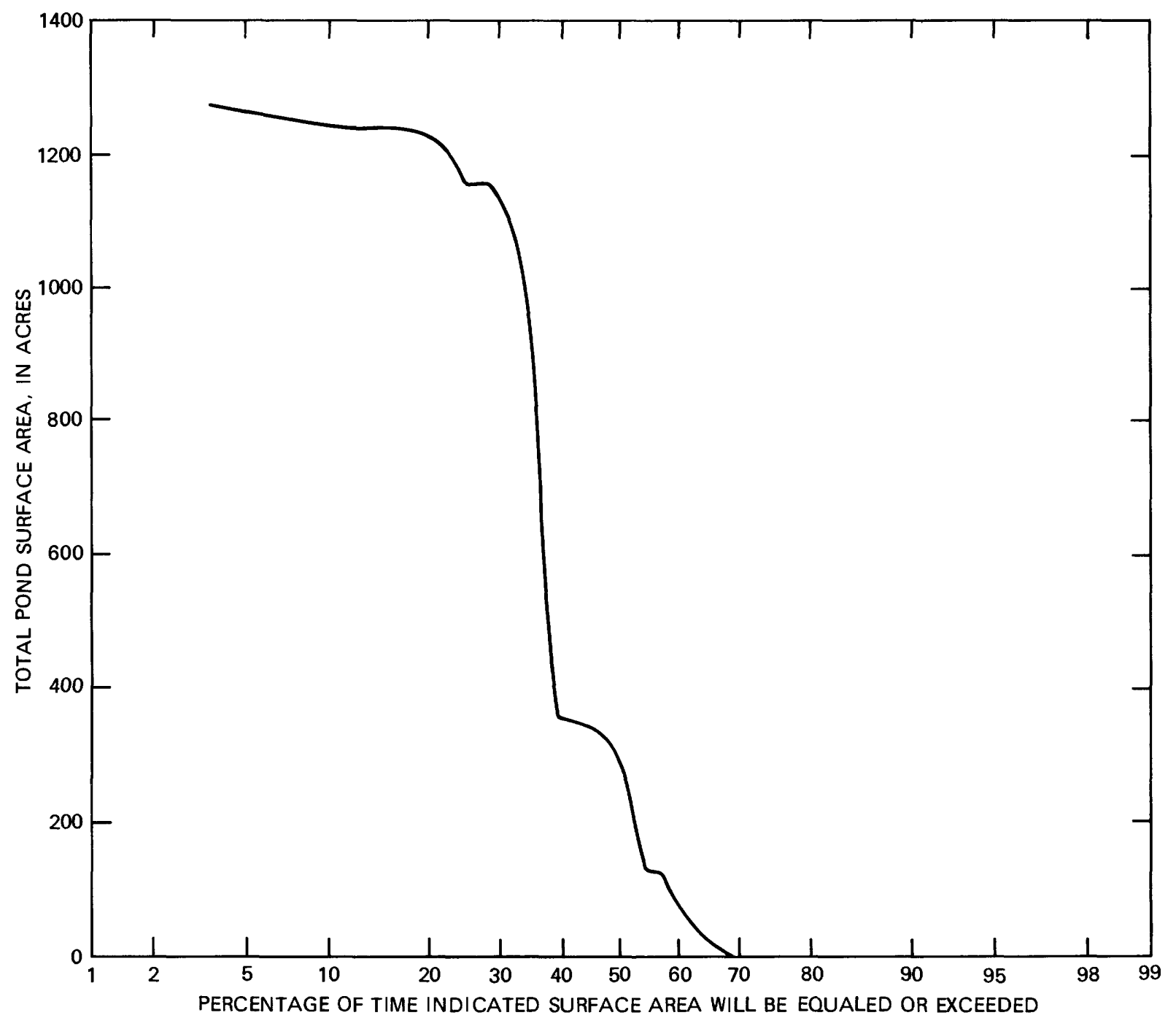

Figure 13.-- Cumulative frequency curve of total pond surface area during April with 27 years of historically developed river diversions. 


\section{Hydrogeologic Setting}

Alluvium underlying the South Platte River valley and the tributary valleys consists of Pleistocene and Holocene terrace deposits and Holocene flood-plain deposits. The terrace deposits form the major part of the alluvium and are continuous upstream along Lost, Kiowa, Bijou, Antelope, Badger, and Beaver Creeks, and contain the major alluvial aquifers in these areas (Bjorklund and Brown, 1957, p. 30). The alluvium consists of interbedded and lenticular deposits of clay, silt, sand, and gravel. McGovern (1964, p. 19) reported, "The Beaver Creek drainage is a complex system of meandering streams that have cut and refilled their channels periodically throughout most of Pleistocene time. Some of the streams presently occupy their original channels, but others do not." McGovern also reported that the alluvial deposits of Beaver Creek valley were generally of local origin. These comments for the Beaver Creek drainage basin also generally apply to the Badger Creek drainage basin.

The maximum thickness of alluvium along Beaver Creek ranges from about $60 \mathrm{ft}$ at the Morgan County line to nearly $100 \mathrm{ft}$ near Brush. Along Badger Creek, the maximum thickness of the alluvium is about $100 \mathrm{ft}$.

Dune sand occurs both east and west of the two alluvial valleys and overlies parts of the alluvium, especially west of Beaver Creek. "In general the areas of dune-sand deposits are good infiltration areas for recharge to the underlying alluvial material" (Bjorklund and Brown, 1957, p. 33).

The Pierre Shale of Late Cretaceous age underlies the alluvium and dune sand. "The Pierre Shale consists of bluish-black marine shale and silt and interbedded tan to yellowish-brown sand and sandy shale in the upper part, or transition zone. Many beds of bentonite and large bluish-grey limestone concretions are present throughout the formation" (Bjorklund and Brown, 1957, p. 19). This formation provides a relatively impermeable base beneath and adjacent to the alluvium and sand dunes.

Natural recharge to ground water beneath the alluvial valleys occurs from precipitation on the valley floors and on the adjacent sand dunes. Except on the sand dunes, "only a small part of the precipitation reaches the ground-water reservoir; most of the water is lost by evapotranspiration before it can percolate downward to the water table" (McGovern, 1964, p. 22). "The potential evapotranspiration rate exceeds the average precipitation rate; thus only during very wet periods is the opportunity favorable for appreciable amounts of water to escape downward to the water table" (McGovern, 1964, p. 22). Also, because the surface area of the alluvial valleys (about $40 \mathrm{mi}^{2}$ ) is considerably smaller than the surface area of the contributing dune sand (estimated to be $200 \mathrm{mi}^{2}$ ), most of the natural recharge to the alluvium along Badger and Beaver Creeks comes from the dune sand adjacent to the alluvial valleys. 


\section{Development of Ground-Water Models}

To predict the effects of artificial recharge on the aquifer system, a ground-water model of each of the two alluvial valley aquifers was constructed. These models consist of a unique set of input parameters describing the respective aquifer systems and a digital computer program which approximates the solution to the ground-water flow equation. The program used is a modification of the standard U.S. Geological Survey two-dimensional, finite-difference model using the iterative, alternating direction, implicit solution technique (Trescott and others, 1976).

To model the aquifers, maps of the areas of interest were first subdivided into a rectangular network of nodes. Beaver Creek valley was subdivided into 37 rows by 27 columns with the largest node representing an area of $0.5 \mathrm{mi}^{2}$ and the smallest node an area of $0.08 \mathrm{mi}^{2}$. Badger Creek valley was subdivided into 33 rows by 24 columns with the largest node representing an area of $0.3 \mathrm{mi}^{2}$ and the smallest node an area of $0.04 \mathrm{mi}^{2}$. The input parameters to these models included the hydraulic head, hydraulic conductivity, specific yield of the aquifer, altitude of bedrock surface, and altitude of land surface at each node. In addition, all the stresses to the aquifer were specified. These stresses included boundary fluxes, pumping, recharge, and discharge to the stream.

All of these stresses are input to the model except discharge to the stream, which is computed by the model. Discharge to a stream was simulated by defining a node to be constant head if the water level at a stream node rose above the bottom of the streambed (as defined by the altitude of land surface). The discharge to all constant head stream nodes was accumulated and accounted for as the surface streamflow leaving the modeled area. If the flow to a stream node reversed directions as water levels in the aquifer declined, thus making the stream a source of water, the designation of a constant head node was discontinued and that node would no longer be considered a part of the flowing stream.

\section{Data Availability}

The most abundant data available for ground-water modeling are water levels. In Beaver Creek valley, south of Brush, water-level data for at least 15 years were available for 24 wells (fig. 14). The hydrographs of these wells (fig. 15) illustrate some interesting trends. Little change in water levels is noted in the southern end of the valley (higher altitudes) since about 1955-60. The date of the initial water-level declines cannot be determined from the available data for that part of the valley. In the northern end of the valley (lower altitudes) the date when water levels began declining moved steadily forward in time. Thirteen wells within the modeled area of Badger Creek valley have at least 10 years of data (fig. 16). Unfortunately, most of these wells are considered part of the South Platte River alluvial aquifer and are in areas that are irrigated by surface-water supplies. The 


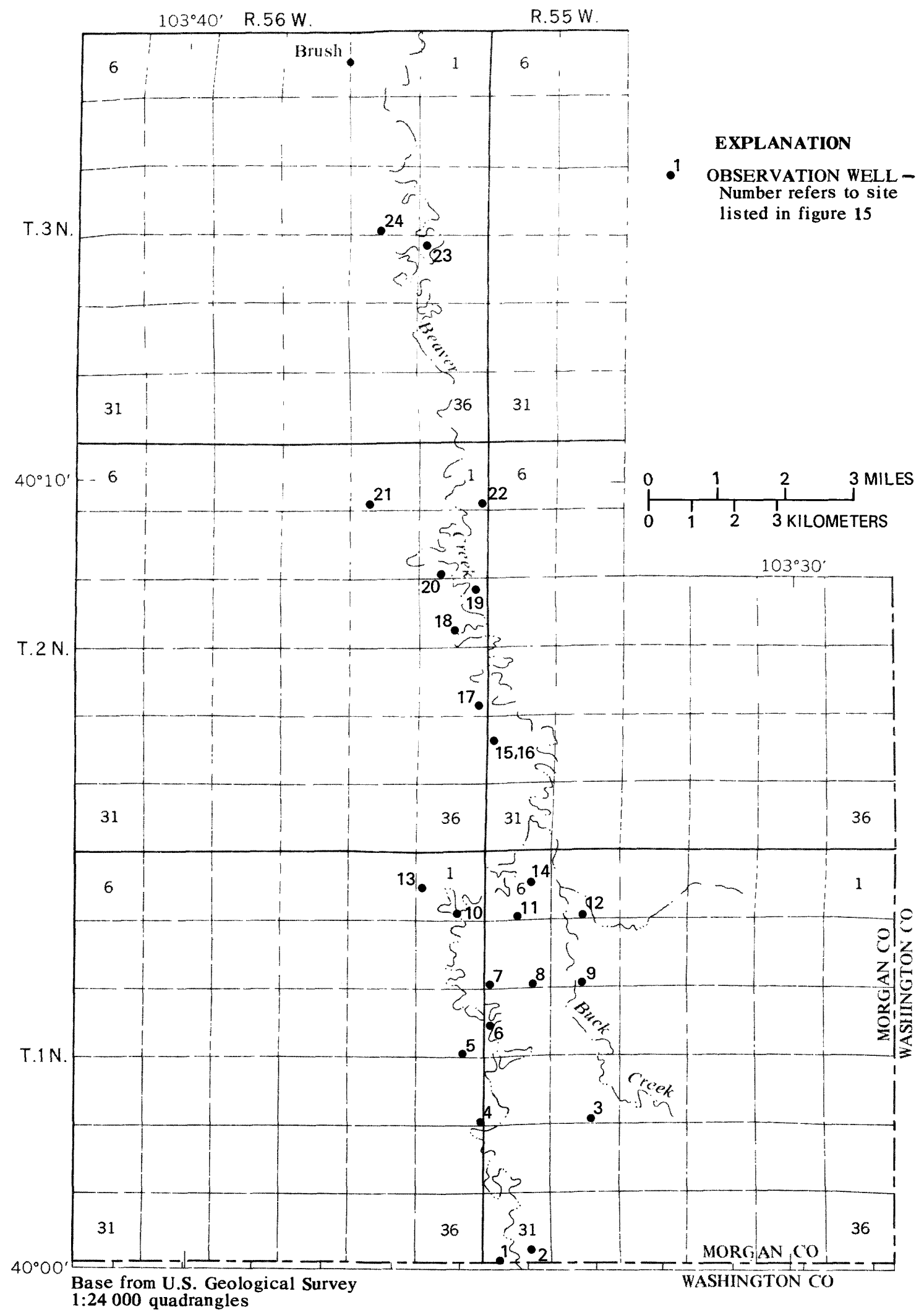

Figure 14.-- Location of wells with long-term water-level data, Beaver Creek valley. 


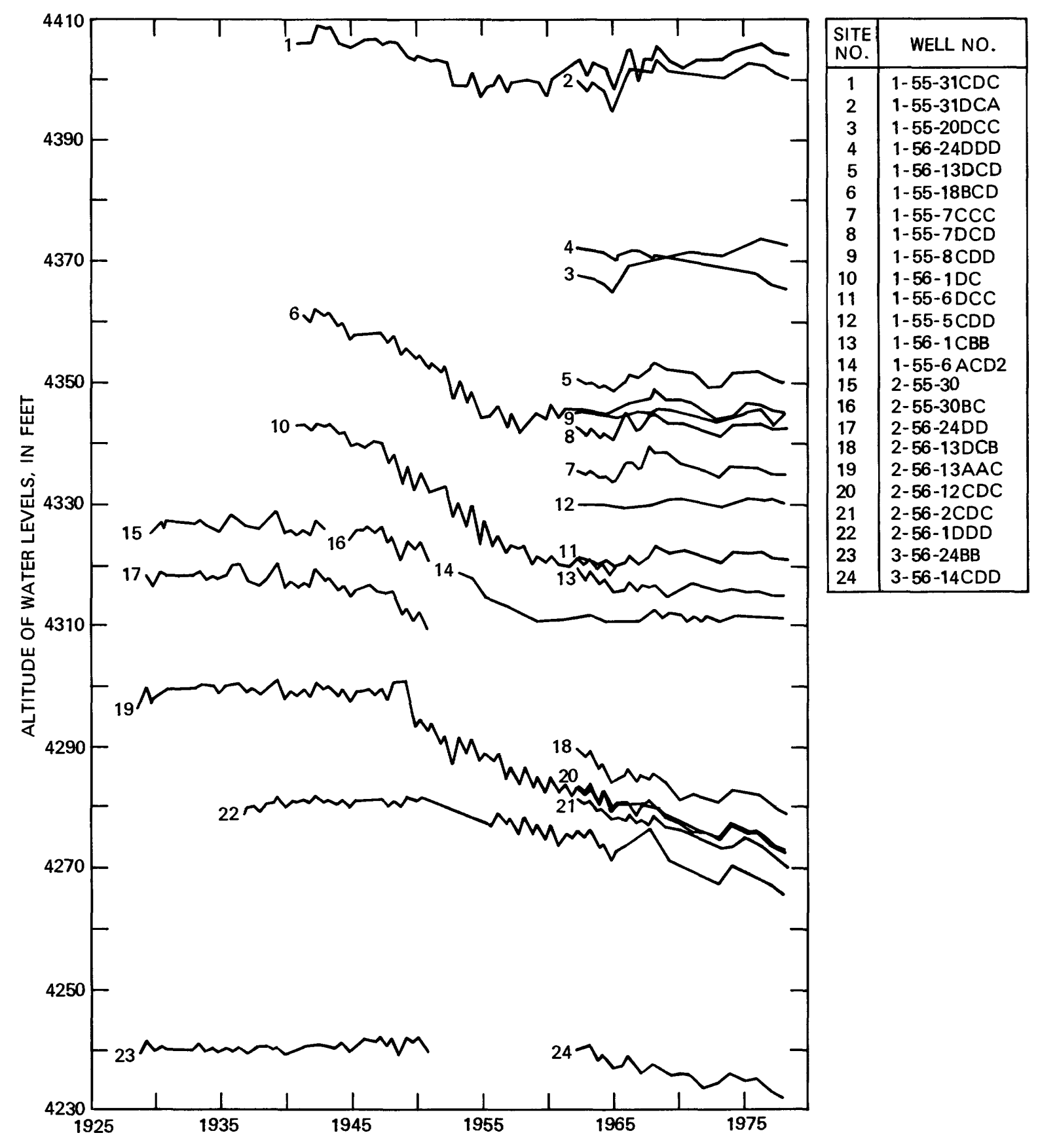

Figure 15.-- Water levels for selected wells in Beaver Creek valley. 


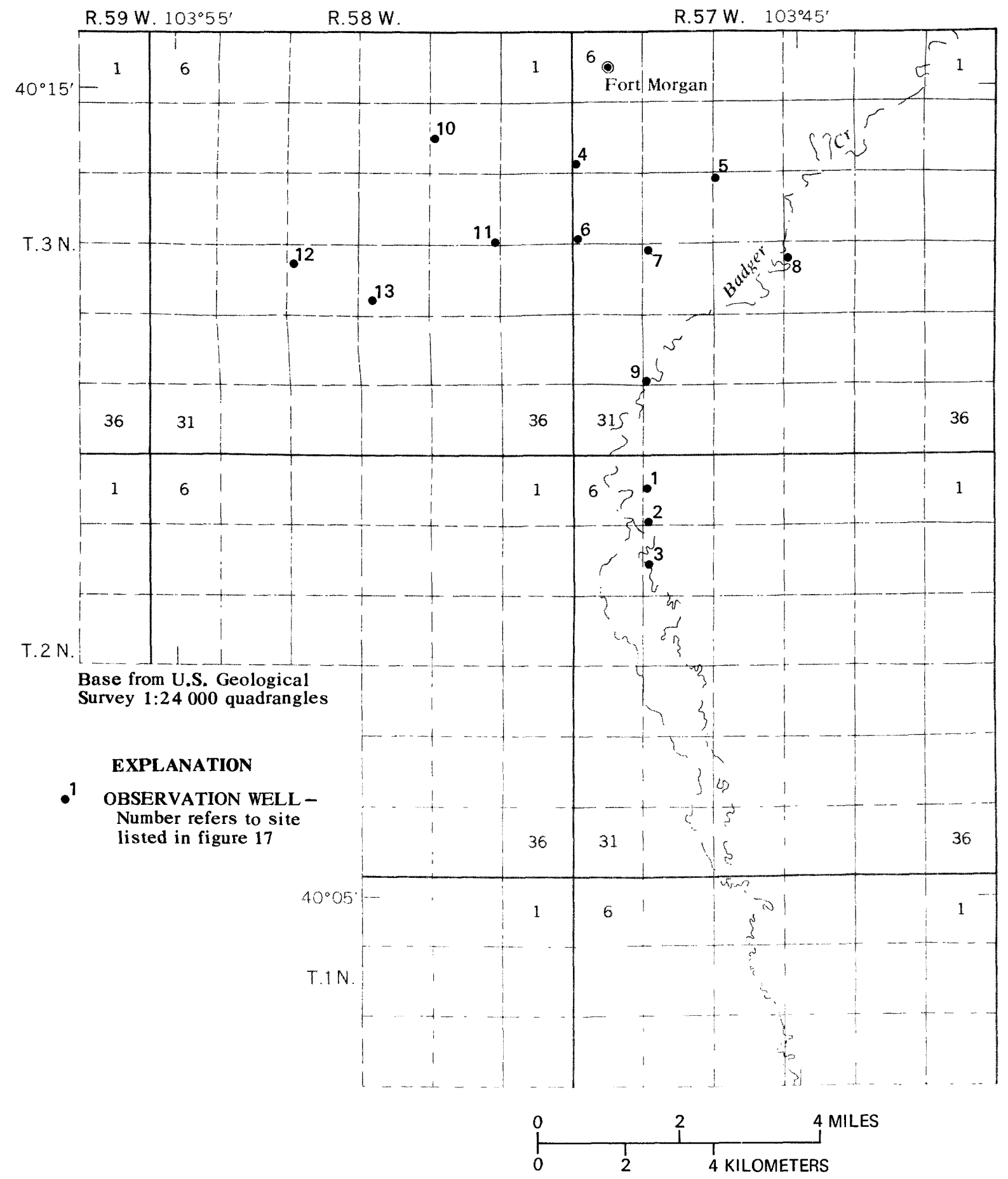

Figure 16.-- Location of wells with long-term water-level data, Badger Creek valley. 


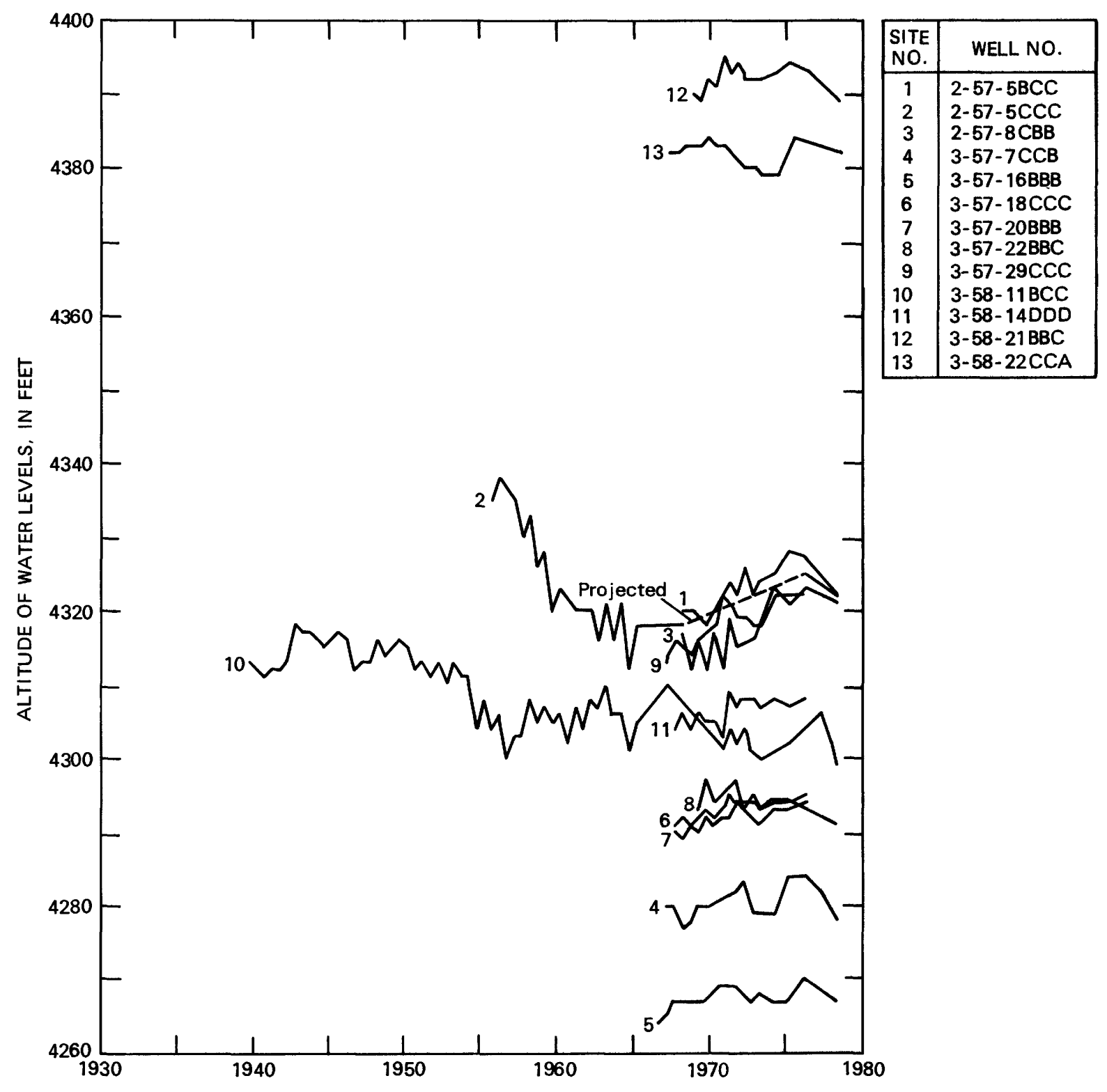

Figure 17.-- Water levels for selected wells in Badger Creek valley. 
hydrographs of wells in the southern end of the valley (fig. 17) show two trends. The only long-term record (well 2-57-5CCC) shows a rather large water-level decline until about 1960. The short-term records generally show slight increases in water levels in this part of the valley since 1967.

In addition to the temporal data indicated in the hydrographs, spatial data collected in 1947 and 1978 were used to plot water-table maps. Watertable maps of Beaver Creek valley (fig. 18) and Badger Creek valley (fig. 19) were drawn from data published by Bjorklund and Brown (1957). As part of this study, water levels in approximately 200 wells were measured in the spring of 1978 (table 19, at back of report). Water-table maps drawn from these data are shown on figures 20 and 21 . Comparison of the figures ( 18 with 20 and 19 with 21) indicates some of the problems of declining water levels faced by the irrigators of this area.

Hydraulic-conductivity data are not generally available for the modeled areas. Transmissivity and saturated thickness maps have been published by Hurr, Schneider, and others (1972a, 1972b) for the South Platte River alluvial aquifers north of this study area. Estimates of hydraulic conductivity obtained from these maps range from 100 to $500 \mathrm{ft} / \mathrm{d}$. Bjorklund and Brown (1957, p. 37) reported the results of two aquifer tests in Beaver Creek valley; computed values of hydraulic conductivity were about 90 and $380 \mathrm{ft} / \mathrm{d}$. Specific-capacity data reported by Bjorklund and Brown (1957, p. 89) ranged from 19 to 65 (gal/min)/ft. Computing transmissivity from the specificcapacity values and dividing by the probable range of saturated thickness gives hydraulic-conductivity values ranging from about 30 to $500 \mathrm{ft} / \mathrm{d}$. There are no specific-yield data for either of the alluvial valleys. Bjorklund and Brown (1957, p. 58) and Hurr, Schneider, and Minges (1975, p. 17) assumed a value of 0.20 for the specific yield of the entire South Platte River valley alluvium. Altitudes of the bedrock surface were obtained from maps published by Bjorklund and Brown (1957). Recontouring was necessary in the area of the sand dunes between the two valleys due to discrepancies in altitudes of bedrock and water-level data. Altitudes of the land surface were obtained from U.S. Geological Survey $7 \frac{1}{2}$-minute quadrangle maps.

Data describing boundary fluxes or recharge were not available for either modeled area. On the basis of information presented in the section on Hydrogeologic Setting, the recharge due to precipitation was assumed to be zero on the valley floor. Recharge in the sand dunes was assumed to enter the modeled areas as boundary fluxes. Recharge in the Badger Creek valley is complicated by the fact that the quantity of surface water used for irrigation is unknown in much of the modeled area. 


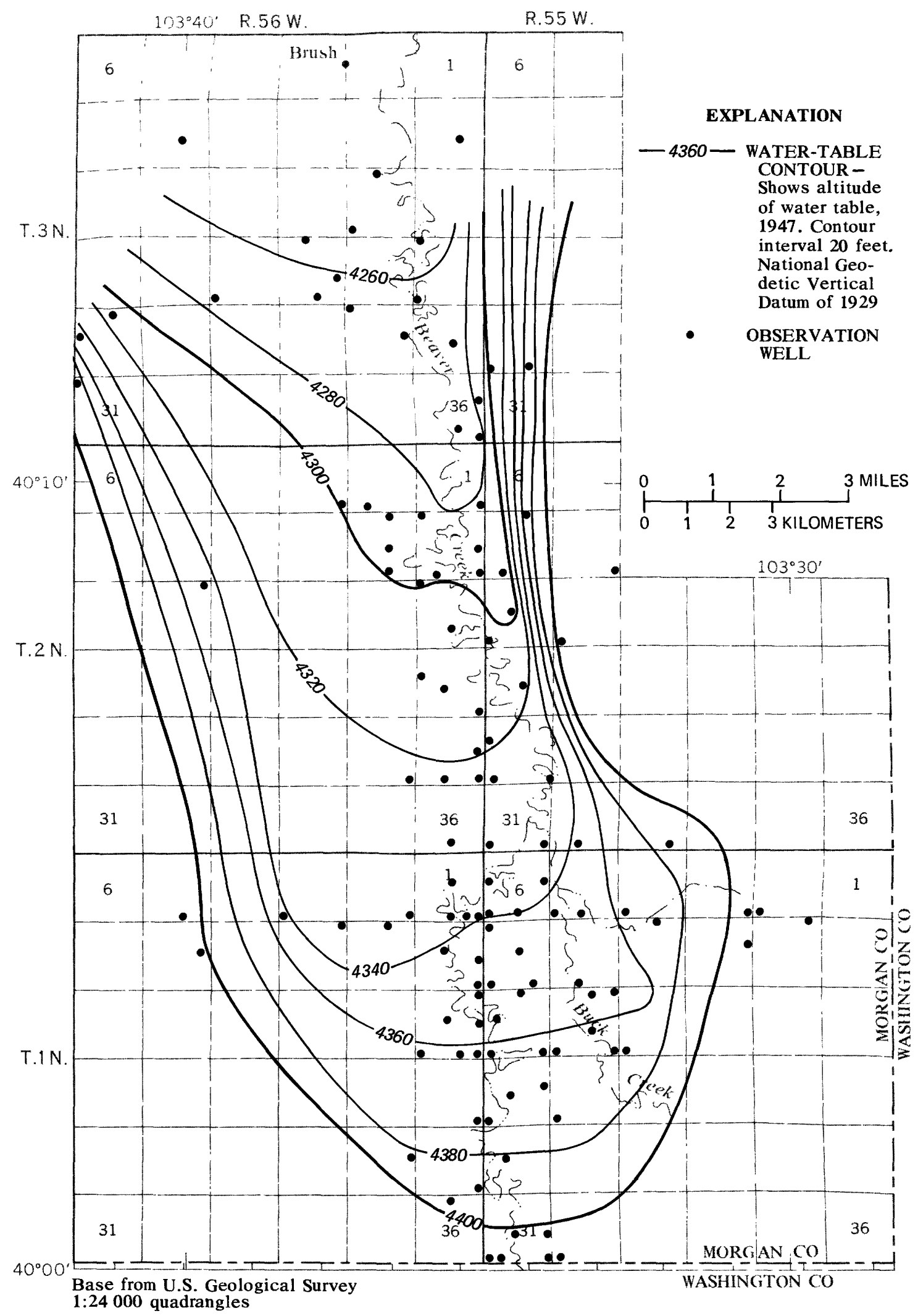

Figure 18.-- Altitude of water table, Beaver Creek valley, 1947. 


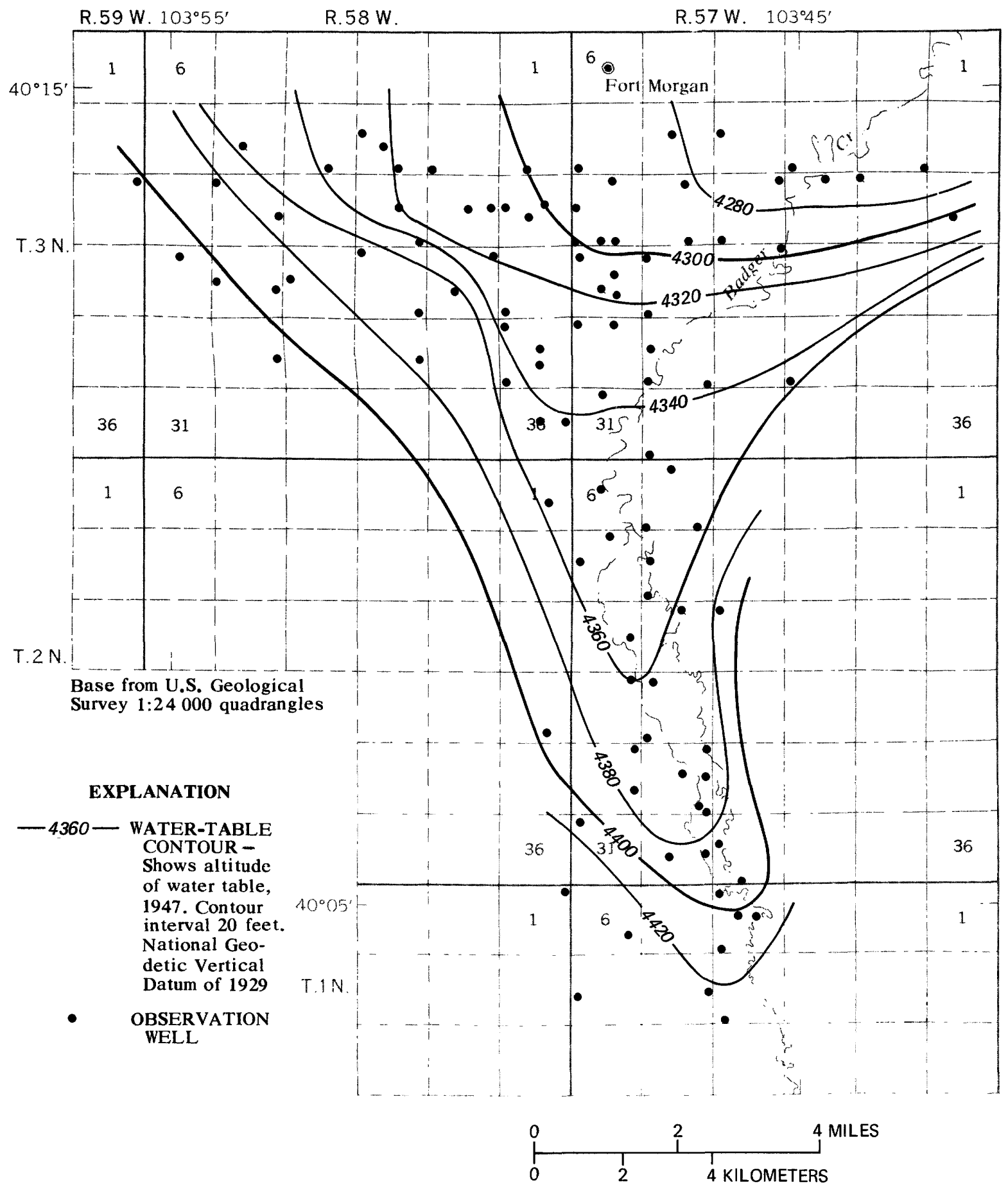

Figure 19.-- Altitude of water table, Badger Creek valley, 1947. 


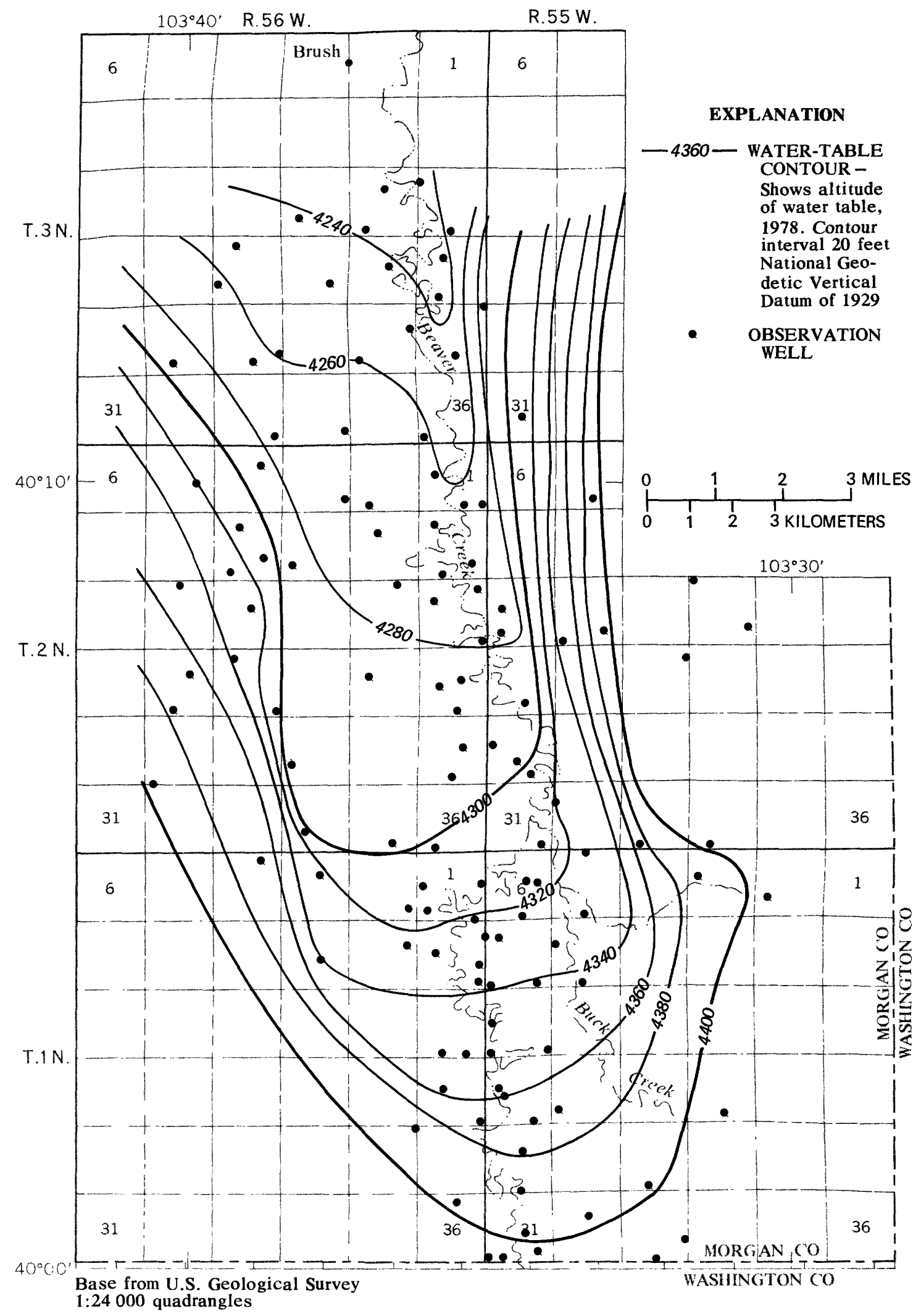

Figure 20.-- Altitude of water table, Beaver Creek valley, 1978. 




Figure 21.-- Altitude of water table, Badger Creek valley, 1978. 
A limited amount of pumping data is available, mostly for the Beaver Creek valley. Published pumping data for Beaver Creek valley collated from various sources is presented in table 10. The pumping rates from year to year were quite erratic. A change in precipitation was hypothesized to be a reasonable indicator for variable rates of application. Data for the 6 years available were plotted versus the annual precipitation for the same year, resulting in the relationship shown in figure 22. A regression analysis of this data resulted in the equation:

$$
A_{p}=2.66-0.093 P_{a}
$$

where $A_{p}$ is the application rate, in feet per year; and

$P_{a}$ is the annual precipitation, in inches.

The equation computes a reasonable estimate of $1.43 \mathrm{ft}$ per year for the average application rate when using the average annual precipitation of $13.2 \mathrm{in}$.

Table 10.--Historic pumping data for Beaver Creek valley

\begin{tabular}{|c|c|c|c|c|c|}
\hline Year & $\begin{array}{l}\text { Number } \\
\text { of } \\
\text { wells }\end{array}$ & $\begin{array}{c}\text { Pumpage } \\
\text { (acre-feet) }\end{array}$ & $\begin{array}{l}\text { Irrigated } \\
\text { acres }\end{array}$ & $\begin{array}{c}\text { Application } \\
\text { rate } \\
\text { (feet) }\end{array}$ & $\begin{array}{l}\text { Precipitation } \\
\text { (inches) }\end{array}$ \\
\hline $\begin{array}{l}1910^{1--} \\
1936^{1--} \\
1940^{1}--\end{array}$ & $\begin{array}{c}\text { First wells } \\
25 \\
53\end{array}$ & - & 4,920 & $\begin{array}{l}--.- \\
---5 \\
1.57\end{array}$ & ---- \\
\hline $\begin{array}{l}1946^{2}-- \\
1947^{2}-- \\
1948^{2}-- \\
1949^{2}-- \\
1950^{2}--\end{array}$ & $\begin{array}{l}109 \\
117 \\
121 \\
135 \\
138\end{array}$ & $\begin{array}{l}11,445 \\
12,084 \\
17,889 \\
17,018 \\
24,343\end{array}$ & $\begin{array}{l}10,191 \\
10,939 \\
11,313 \\
12,623 \\
12,903\end{array}$ & $\begin{array}{l}1.12 \\
1.10 \\
1.58 \\
1.35 \\
1.89\end{array}$ & $\begin{array}{r}17.42 \\
13.76 \\
12.57 \\
15.10 \\
9.45\end{array}$ \\
\hline $1972^{3}--$ & --- & $-\ldots-$ & 16,500 & ---- & ---- \\
\hline
\end{tabular}

${ }^{1}$ Code, 1943.

${ }^{2}$ Bjorklund and Brown, 1957.

${ }^{3}$ Computed from U.S. Department of Agriculture, 1972.

If there were no precipitation, irrigation applications would have to total the crop consumptive use. This equation results in a reasonable estimate of $2.66 \mathrm{ft}$ per year for crop consumptive use if there were no precipitation. Cumulative irrigated acreage and an implied increase in pumping are shown in figure 23. These data were obtained from a list of well permits on file with the Conservancy District (Thomas Norton, written commun., 1978). By estimating the land irrigated by each well and tabulating the date of drilling, the area of irrigated land was computed. This curve has limitations in accuracy because many wells were constructed as replacement wells as water levels declined. Thus the curve does not include the effects of cessation of pumping replaced wells. 


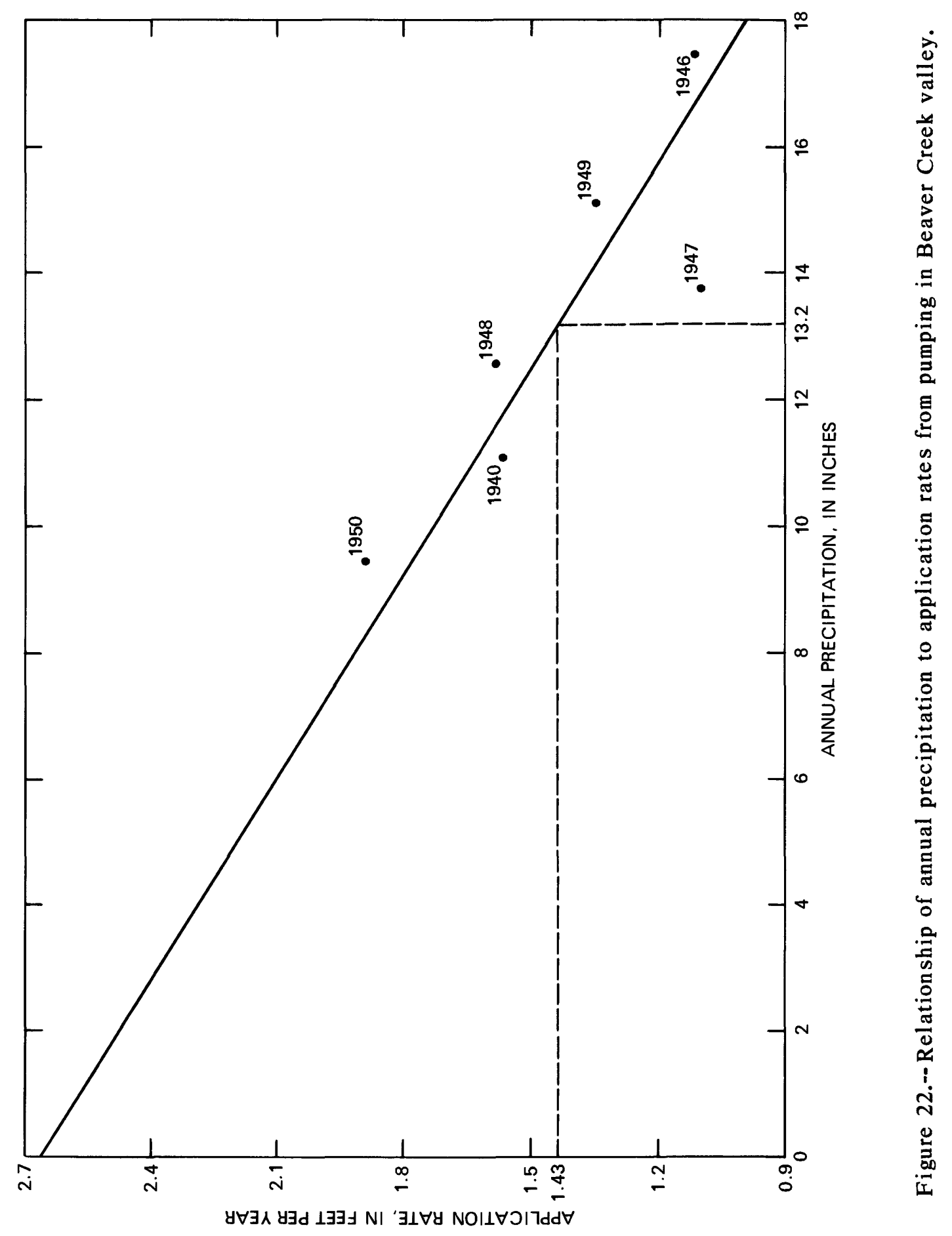




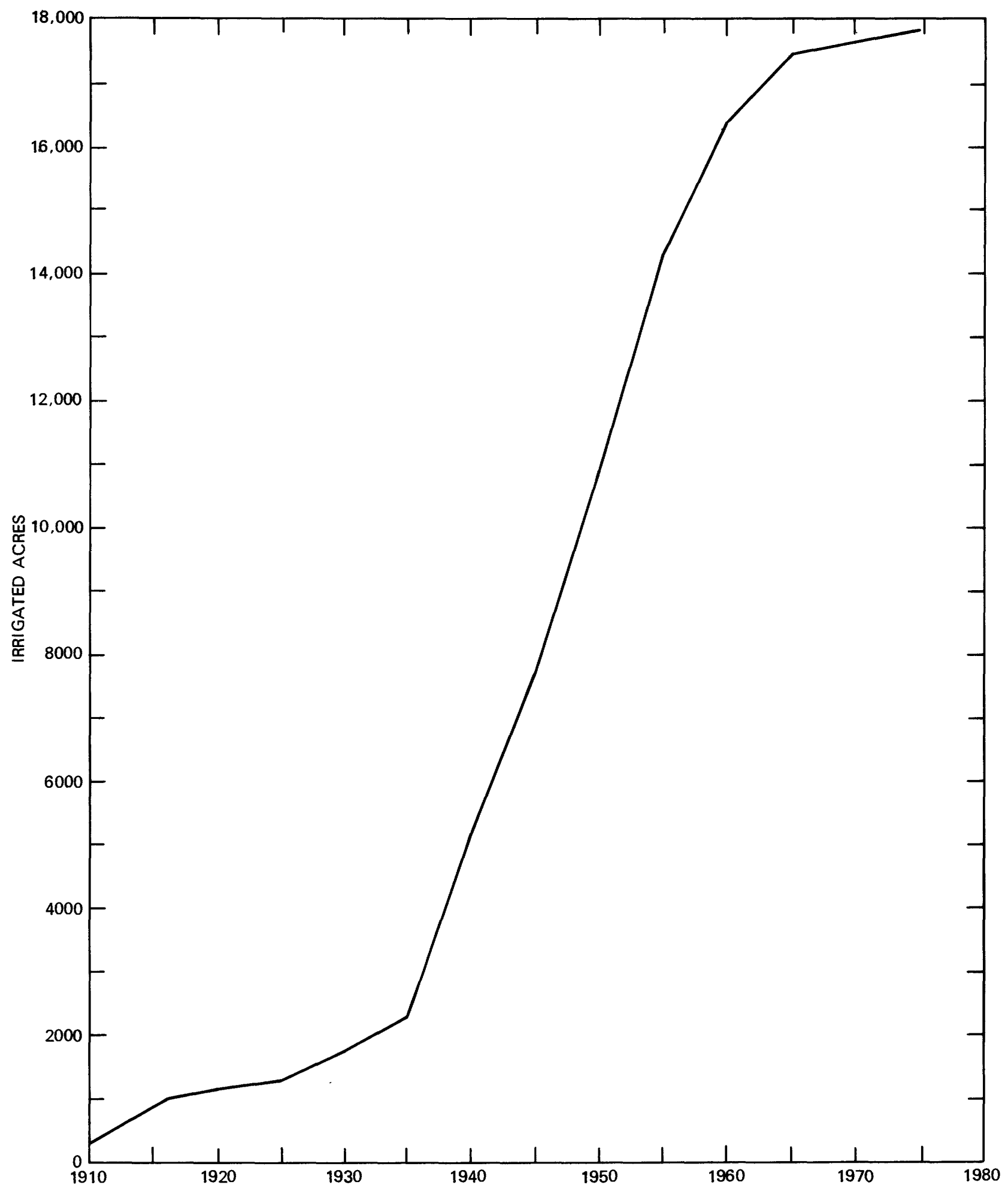

Figure 23.-- Cumulative irrigated acreage in Beaver and Badger Creek valleys. 


\section{Calibration of the Beaver Creek Valley Model}

Calibration of a digital ground-water model consists of entering known and estimated input data, running the model for some historic period of stress, comparing modeled water levels to measured water levels, and then adjusting certain input data until the modeled and measured water levels compare within some acceptable limit of error. Typically, the boundary fluxes and historic stresses are known and most adjustments of input data involve the storage coefficient and the transmissivity. In this study, however, due to a lack of data, boundary fluxes and historic stresses also were adjusted during calibration.

Boundary fluxes were the first variables estimated for the Beaver Creek valley model. These boundary fluxes are the only source of water into the model, representing the flow of water through the alluvial valley from the south and from the sand dune areas to the east and west. The recharge to the alluvial aquifer from the occasional flooding of Beaver Creek and recharge from intense precipitation on the valley floor were ignored for the average conditions being modeled. To determine the order of magnitude for estimated inflow, the possible recharge from the sand hill area was computed. If 3 in. per year of precipitation were recharged--2.5 in. per year of recharge was computed for Frenchman Creek basin, Nebraska, less than $100 \mathrm{mi}$ east of this site, where precipitation is about 75 percent greater but only one-third of the basin is sand dunes (Lappala, 1978)--over the approximately $200 \mathrm{mi}^{2}$ of sand dunes, a total of about $44 \mathrm{ft}^{3} / \mathrm{s}$ would be available to enter the two alluvial valleys.

The steady-state flux across the boundaries and into the stream channel was computed for the water-table configurations in 1947 and 1978. A uniform hydraulic-conductivity value was used for these computations. The initial simulation, using a hydraulic conductivity of $500 \mathrm{ft} / \mathrm{d}$, resulted in a boundary flux and streamflow values that were much too large. Although no discharge data were available for Beaver Creek, $25 \mathrm{ft}^{3} / \mathrm{s}$ was estimated to be the maximum possible average annual flow in 1947 and there was no flow in 1978. Pumpage in 1947 was reported to total about 12,000 acre-ft, which converts to about $16 \mathrm{ft}^{3} / \mathrm{s}$, and in 1978 pumping was assumed to be somewhat greater. On the basis of these values, the estimate of hydraulic conductivity was adjusted to about $90 \mathrm{ft} / \mathrm{d}$. Using the water-table values of 1947 , the flux at each of the individual nodes along the boundary was computed; the sum was $21 \mathrm{ft}^{3} / \mathrm{s}$. The values estimated using the 1978 water-table configuration were thought to be more accurate. This is because there was no flow in Beaver Creek, so the hydrologic system is less complex and the hydraulic-head data are affected by fewer external conditions. Also, the change in water levels was smaller in 1978 than in 1947, so the hydrologic system was closer to a steady-state condition. The sum of the fluxes using the 1978 water-table values was $23 \mathrm{ft}^{3} / \mathrm{s}$. 
The method chosen to calibrate the model was to run the model from 1920 to 1980 and to try to match the water-table contours in 1947 and 1978 and fit water-level hydrographs with at least 20 years of record. The initial water table for the model run was assumed to be the preirrigation steady-state condition--before any pumping occurred. This water-table configuration was computed by running the model with the computed boundary fluxes and no pumping, and solving for the position and flow of Beaver Creek. The simulation was run to steady-state so that the constant flux out of the north end of the modeled area plus the streamflow in Beaver Creek equaled the boundary-flux inflow.

The model was run for the 60-year period starting at this initial, nopumping condition. Estimating the distribution of pumping both spatially and temporally was a part of the calibration process. The model allowed pumping to occur only in those nodes where wells occur, as delineated from the wellpermit list. In the first calibration attempt, the total pumping was evenly distributed to each of these nodes. However, it is known that historic irrigation was more concentrated at the southern end of the valley and increased in the northern end at a later time. Thus, a function was built into the model which weighted the distribution of the total pumping to the southern end prior to 1953 and toward the northern end after that date. Also programed into the model was the feature to decrease pumping at a node proportionately as the saturated thickness decreased from its initial value. Finally, a driving function for total annual pumpage from all wells in the entire valley was input to the model. This driving function was generated to correspond to the curve in figure 23 until 1955. An abrupt change in pumping was attributed to excessive drawdowns caused in part by the extreme drought conditions from 1953 to 1956. Since that time irrigation and pumping reportedly have declined steadily (Robert Samples, Water Commissioner, oral commun., 1978). The pumping rates computed by the model as a result of these different functions are shown on figure 24. The driving function assumed average precipitation every year to smooth out the vagaries in pumping estimates due to fluctuating precipitation ( $f i g .22$ ).

0 ther than the adjustments to the pumping functions and values, the only significant change made to the input data during calibration was the distribution of hydraulic conductivity. The 1947 water-table simulation closely matched actual conditions, but the 1978 water-table simulation was too high in the western part of the model where the sand dunes occur. Because there was no evidence to suggest an unidentified withdrawal in that area, and the area in question was too far from the boundary for modifications in the boundary flux to help, the only useful modification to the data was to increase the hydraulic-conductivity values in that area to about $400 \mathrm{ft} / \mathrm{d}$. 


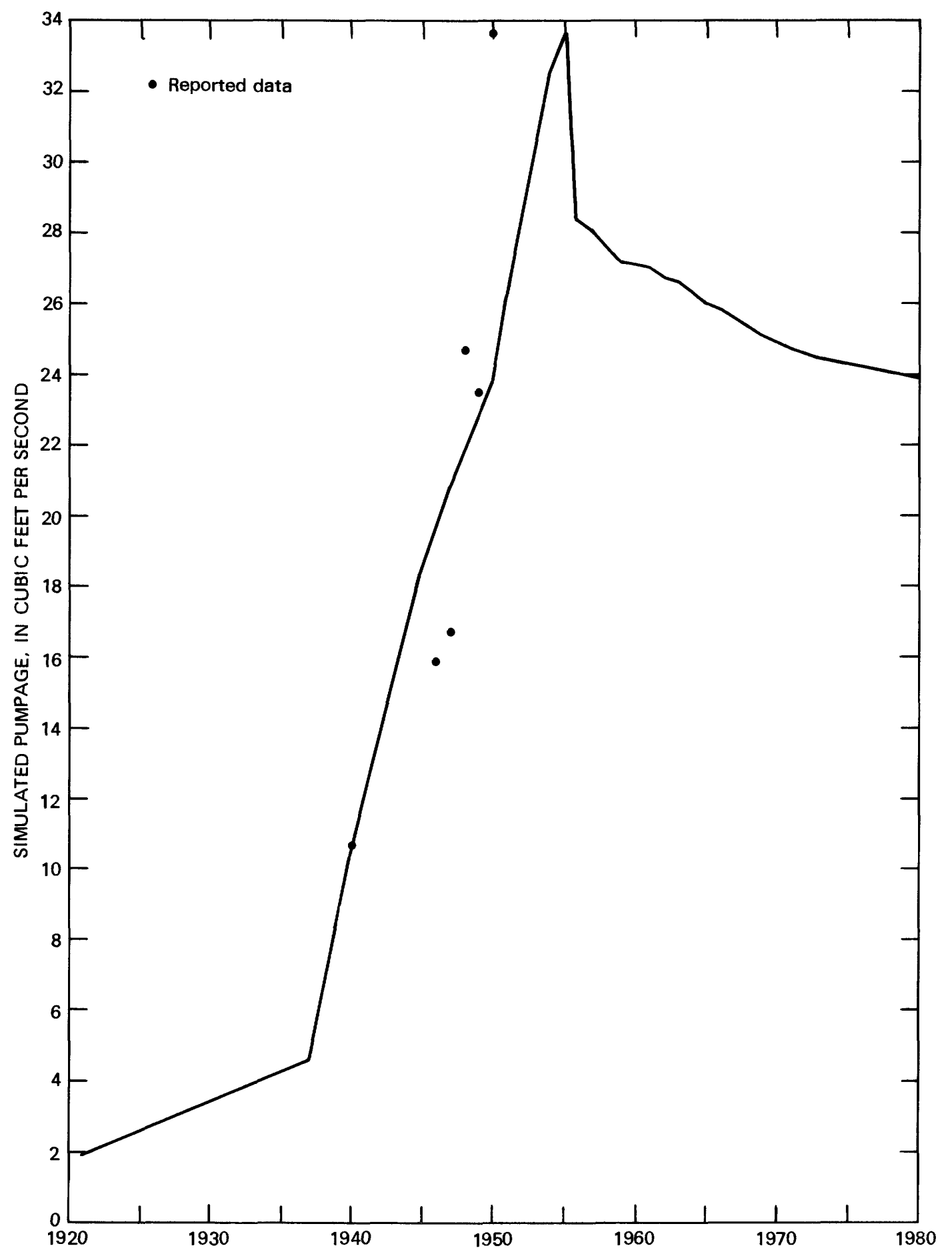

Figure 24.-- Simulated historical pumping in Beaver Creek valley. 
After adding the region of higher hydraulic conductivity in the area of the sand dunes and making a few minor adjustments to specific yield, pumping, and boundary fluxes, the model was run in annual time increments simulating 60 years. The new initial condition was computed and the simulated watertable configuration is shown on figure 25. As indicated in table 11 , the simulated streamflow in Beaver Creek was $20.9 \mathrm{ft}^{3} / \mathrm{s}$. The simulated water table for 1947 (fig. 26) can be compared to figure 18 and the simulated water table for 1978 (fig. 27) can be compared to figure 20. The general water budgets for these 2 years are summarized in table 11 . Additional substantiation that the model is reasonably calibrated can be seen by the comparisons of the simulated water levels to the measured hydrographs of the six wells having at least 20 years of record (figs. 28-33). Although some of the simulated results are somewhat less than measured water levels, considering the possible range of water levels and the fact that the actual observation wells are not located in the middle of the simulated nodes, the results are not thought to be unreasonable.

Table 11.--Simulated water budgets for Beaver Creek valley computed during calibration

$\begin{array}{lll}\text { Preirrigation } & 1947 & 1978\end{array}$

Cubic feet per second

Inflow:

Boundary flux---- $\quad 23.1 \quad 23.1 \quad 23.1$

Outflow:

\begin{tabular}{|c|c|c|}
\hline Pumping--- & 0 & 20.8 \\
\hline Streamf low-- & 20.9 & 9.9 \\
\hline Boundary flux------ & 2.2 & 2.2 \\
\hline hange in st & 0 & -9.8 \\
\hline
\end{tabular}




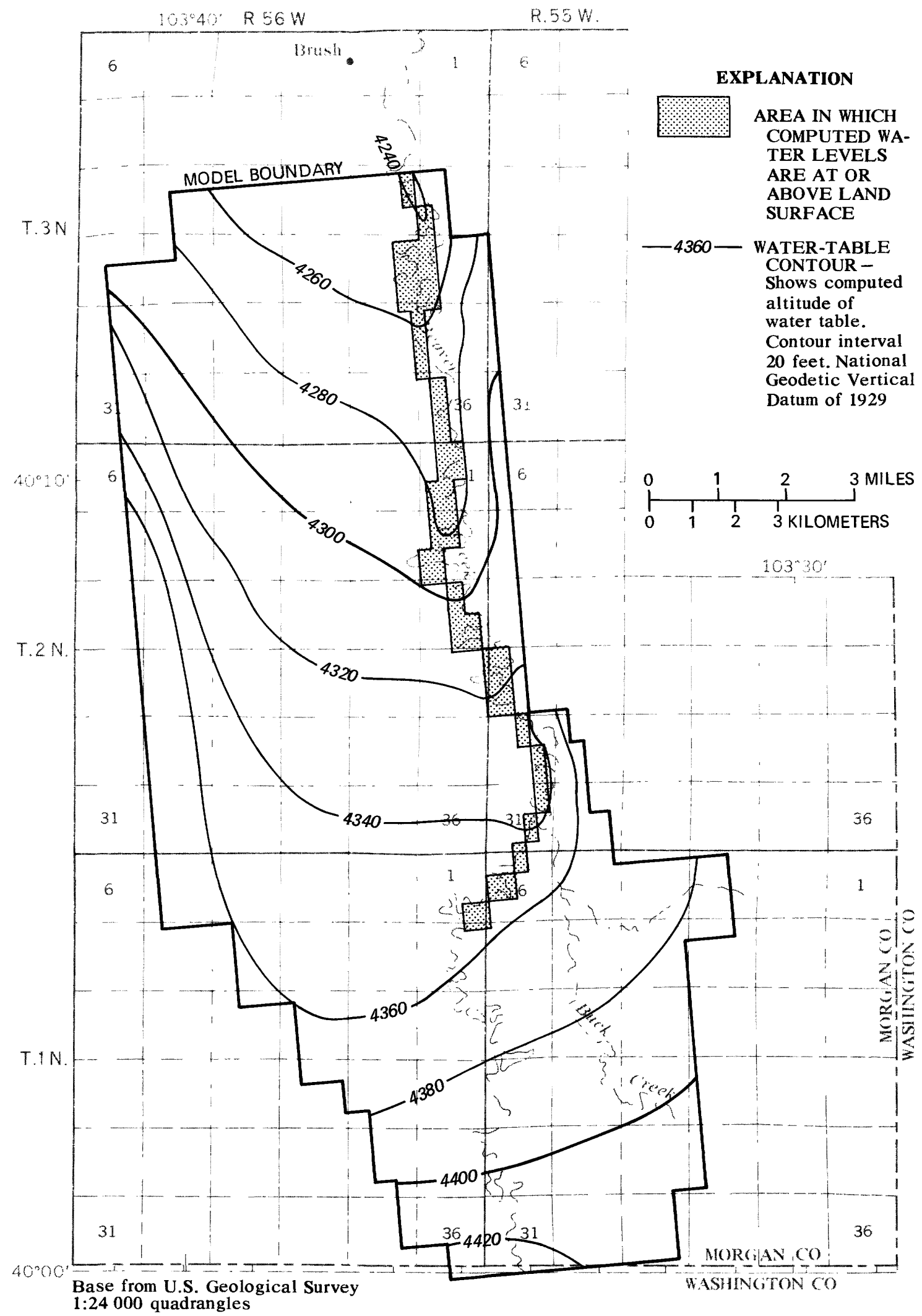

Figure 25.-- Altitude of water table computed by the model, Beaver Creek valley, preirrigation conditions. 




Figure 26.-- Altitude of water table computed by the model, Beaver Creek valley, 1947. 




1:24 000 quadrangles

Figure 27.-- Altitude of water table computed by the model, Beaver Creek valley, 1978. 


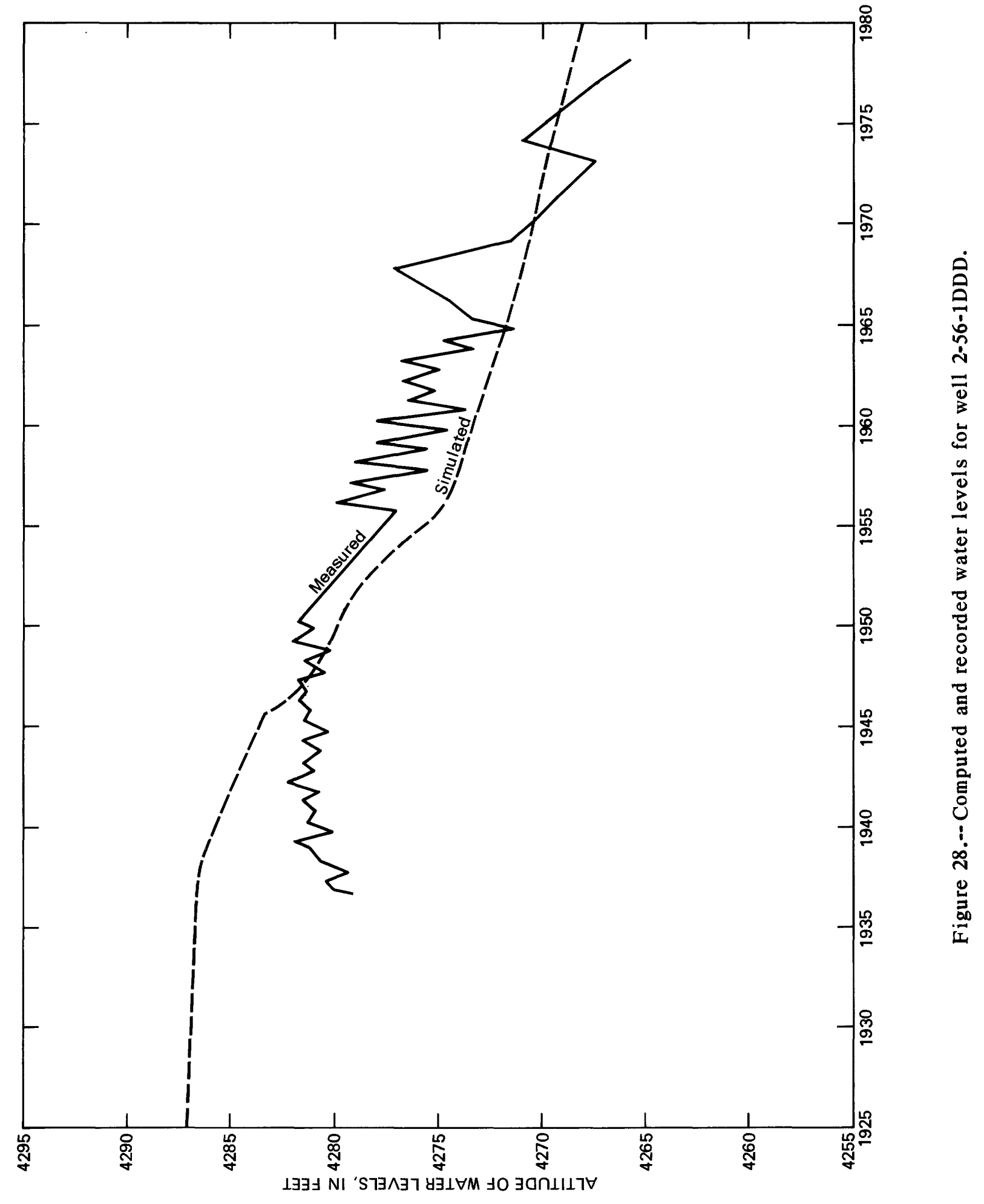









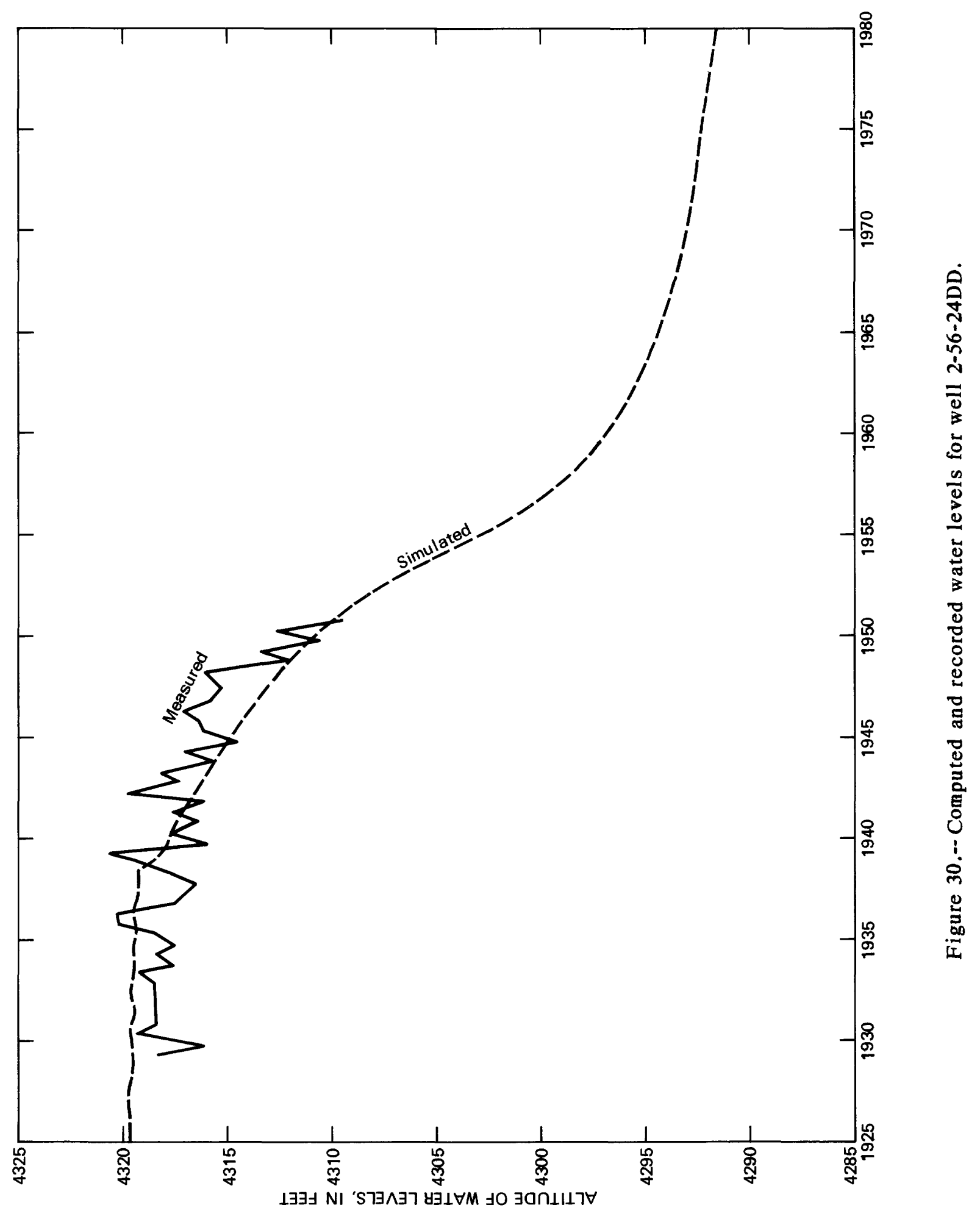




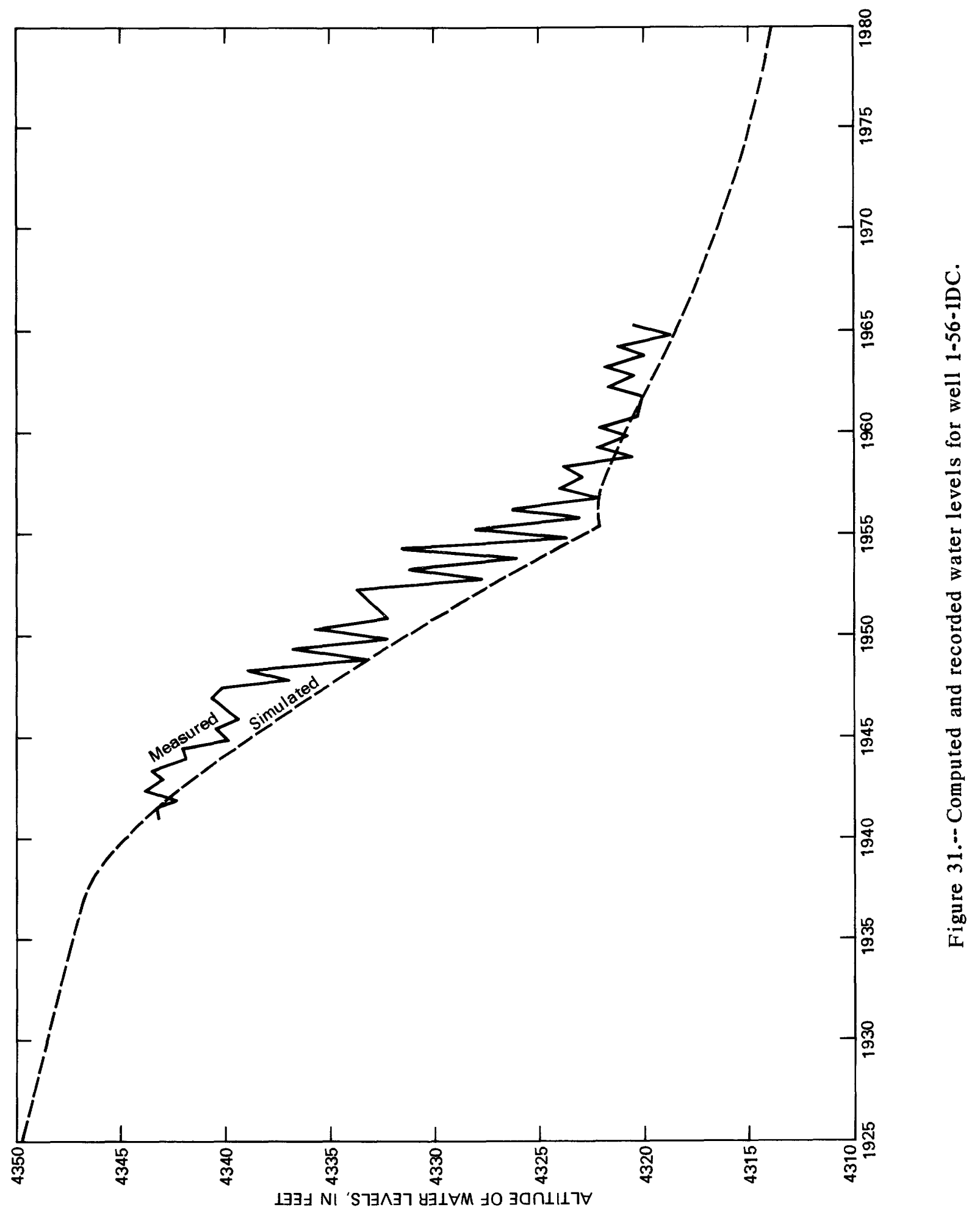




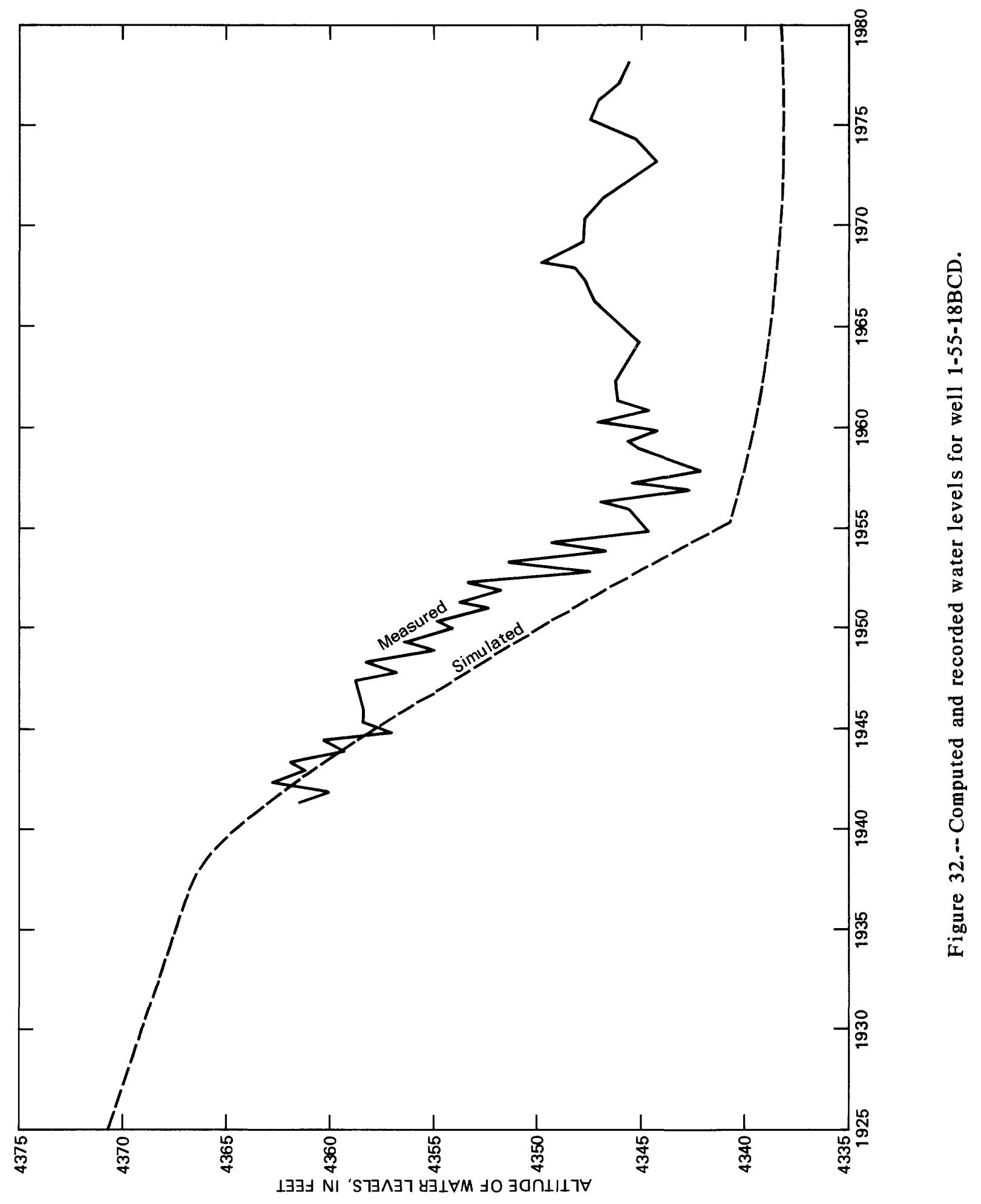




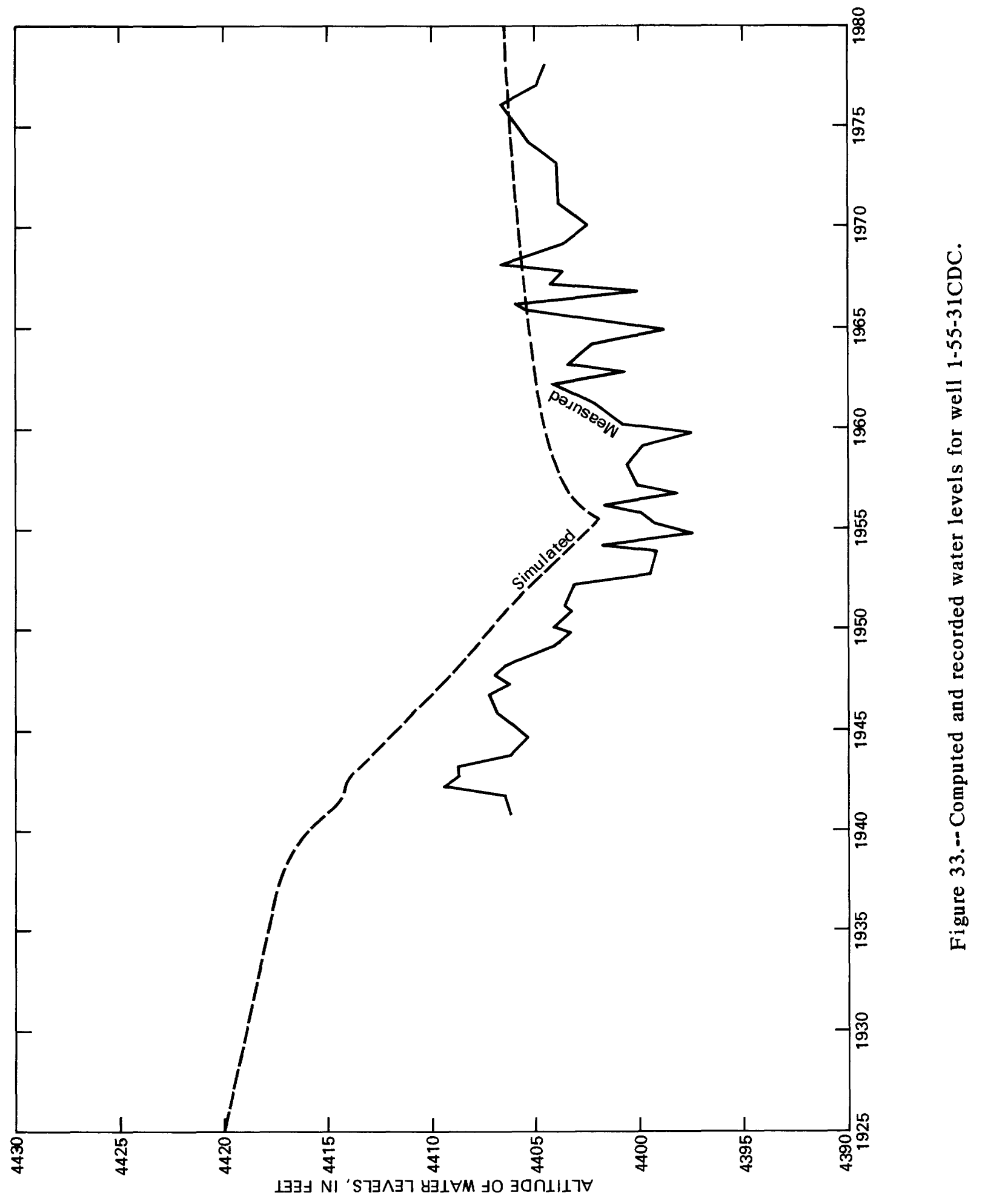


Calibration of the Badger Creek valley model was complicated by three factors: (1) Data with which to reconstruct historic development, particularly water-level data, are less abundant than for Beaver Creek valley; (2) much of the modeled area is part of the South Platte River alluvium with water levels controlled by the regional system; and (3) much of the modeled area is irrigated by unknown quantities of surface water. Because of these factors, the model was not calibrated to the detail achieved for the Beaver creek valley model. The hydraulic-conductivity value used was a uniform value of $90 \mathrm{ft} / \mathrm{d}$ (the same as that used in most of the areas for Beaver Creek valley).

A technique was used to compute the flux at each node that would maintain hydraulic heads at the level contoured using the 1978 data. In total, these fluxes provide useful information relative to boundary fluxes, net withdrawal, and recharge. The value at any individual node is not, however, a very reliable estimate of the site-specific recharge or discharge. This is because: (1) The technique cannot smooth out the disjunctive water table created when using 10- $\mathrm{ft}$ contour intervals; (2) an average water level (at the center of a nodal area) needs to be specified; and (3) the computed accretion or depletion is extremely sensitive to the head values used in the computation.

Results of this technique indicate that the boundary inflow, which occurs along all but the northern edge and part of the northeastern corner of the valley, totals about $17 \mathrm{ft}^{3} / \mathrm{s}$. Boundary outflow to the South Platte River valley is about $9 \mathrm{ft}^{3} / \mathrm{s}$. Assuming that the system is nearly in a steady-state condition (a reasonable assumption, considering the lack of changes in the water-level data and the results of the Beaver (reek model), net discharge from within the valley is $8 \mathrm{ft}^{3} / \mathrm{s}$. Known recharge from surface-water applications in much of the northern part of the modeled area would indicate that total withdrawals annually certainly exceed $8 \mathrm{ft}^{3} / \mathrm{s}$.

To confirm the occurrence of recharge and pumping, another simulation run was made with all of the hydraulic heads at the boundary nodes being held constant. The drawdown configuration ( $\mathrm{fig}$. 34) resulting from this simulation shows the decline in water levels in the northwestern part of the modeled area if there were no recharge in those areas to maintain heads as they are now. Likewise, a rise in water levels would occur in the southern part of the modeled area if there were no pumping causing the lower levels that were measured.

\section{Predicted Conditions in Beaver Creek Valley}

Many simulations were made to provide planners with a variety of conditions for consideration during the design of the project. Alternatives using different combinations of proposed recharge, pumping, and time periods included: 
1. No recharge with current pumping and annual time steps.

2. Median-diversion recharge with current pumping and annual time steps.

3. Median-diversion recharge with current pumping and monthly time steps.

4. Historic-diversion recharge with current pumping and monthly time steps.

5. Median-diversion recharge with increased pumping and annual time steps.

6. Median-diversion recharge with maximum increased pumping and annual time steps.

Those alternatives with annual time steps used elapsed times of either 100 years or continued until a steady-state was achieved, whichever occurred first. The order of the alternatives discussed in this report follows the study as it was presented during frequent oral progress reports and reflects the questions and desires of interested persons expressed during the study. Several simulations were repeated for some of these alternatives, assuming different canal configurations. The results of these simulations are presented in tables but discussions in the text are limited to the configuration of the entire canal system with 65 ponds.

The first alternative simulated was for no artificial recharge. As noted in table 11, the Beaver Creek valley aquifer system is currently (1978) estimated to be in an overdraft condition--pumping plus natural discharge exceeds natural recharge. Unless pumping is further reduced, water levels will continue to decline. During 15 years at the current (1978) pumping rate, little change would occur in the southern one-half of the modeled area but in the northern one-half, water levels would decline as much as $15 \mathrm{ft}$. After 25 years, some areas would become desaturated and some water-level declines would exceed $25 \mathrm{ft}$. In the thirty-fourth year of simulation, the model could no longer compute a solution because there were large areas of totally desaturated alluvium. This simulation did not assume any reduction in pumping as water levels declined. In reality, less water could be pumped from wells as water levels declined, and thus land would be taken out of irrigation; this would progress until a new equilibrium eventually would be reached.

A set of five different artificial-recharge inflows, generated by the canal-distribution model (table 6 ), were input into the model while maintaining pumping at the estimated current rate. Water budgets for each of these alternatives under steady-state water-table conditions are summarized in table 12. For each alternative, the artitificial recharge eventually brings a halt to the overdraft condition. The additional recharge to water levels can be great enough to create a flowing stream. On the other hand, a recharge-discharge system could be designed to bring the system to a steadystate condition where water levels would support pumping but where streamflow would not be supported. 


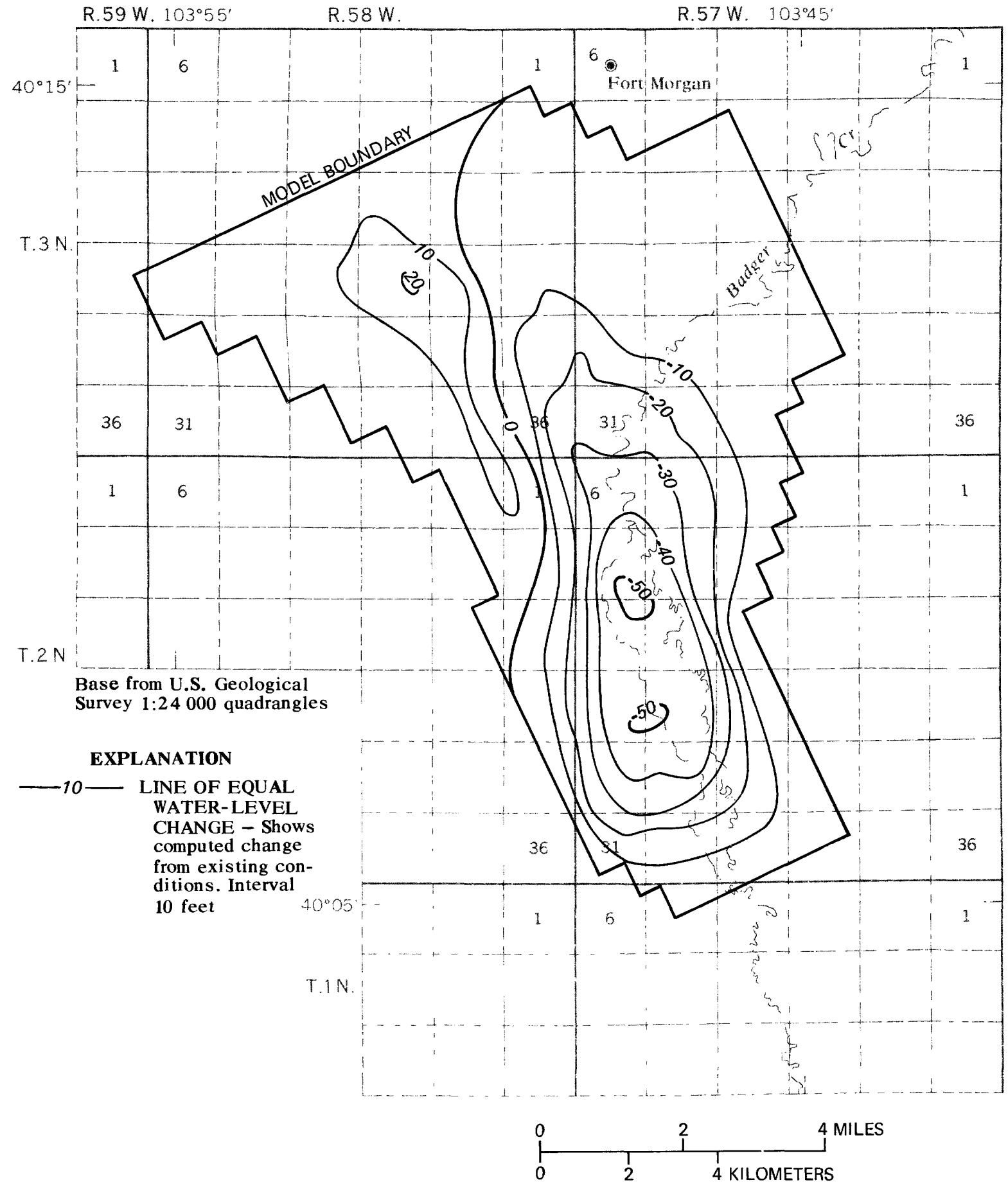

Figure 34.-- Change in 1978 water table in the absence of local recharge or discharge as computed by the model for Badger Creek valley. 
Table 12.--Steady-state water budgets computed by the model for five artificial-recharge configurations using median-diversion recharge with estimated current pumping, Beaver Creek valley

\begin{tabular}{|c|c|c|c|c|c|}
\hline & $\begin{array}{l}\text { Entire } \\
\text { canal } \\
\text { system } \\
\text { with } \\
7 \text { ponds }\end{array}$ & $\begin{array}{c}\text { Entire } \\
\text { canal } \\
\text { system } \\
\text { with } \\
65 \text { ponds }\end{array}$ & $\begin{array}{c}\text { Beaver } \\
\text { Creek } \\
\text { valley } \\
\text { only }\end{array}$ & $\begin{array}{c}\text { Recharge } \\
\text { canals } \\
\text { only }\end{array}$ & $\begin{array}{c}\text { Recharge } \\
\text { canals } \\
\text { plus } \\
\text { extension }\end{array}$ \\
\hline Inflow: & \multicolumn{5}{|c|}{ Cubic feet per second } \\
\hline Boundary flux--.-- & 23.1 & 23.1 & 23.1 & 23.1 & 23.1 \\
\hline Recharge---no & 20.0 & 19.4 & 28.5 & 18.5 & 19.2 \\
\hline \multicolumn{6}{|l|}{ Outflow: } \\
\hline Pumping---n & 24.0 & 24.0 & 24.0 & 24.0 & 24.0 \\
\hline Streamflow-- & 16.9 & 16.3 & 25.4 & 15.4 & 16.1 \\
\hline Boundary flux- & 2.2 & 2.2 & 2.2 & 2.2 & 2.2 \\
\hline
\end{tabular}

The steady-state water-table configuration for the proposed canal layout using all of the canals and stream channels is shown in figure 35 . The parts of the stream that are shown at or above land surface represent those areas where the simulated water table would rise above the bottom of the streambed and cause a flowing stream. The other areas where the water table would rise above the land surface represent waterlogged areas. The model did not account for additional evapotranspiration nor a change of seepage rates computed by the distribution model in any of these waterlogged areas. These need to be accounted for in future analysis of this project as they will reduce the waterlogged areas but they also will represent a loss of water to the system that agricultural interests would consider a nonbeneficial use. For instance, evapotranspiration losses in the areas shown on figure 35 could be as much as $4 \mathrm{ft}^{3} / \mathrm{s}$, and this loss would probably reduce the flow in Beaver Creek (table 12) by about 25 percent. The model computed that it would take 57 years to reach steady-state with this recharge and pumping configuration, although from figure 36 it can be seen that the system nearly reaches equilibrium within 15 years. 


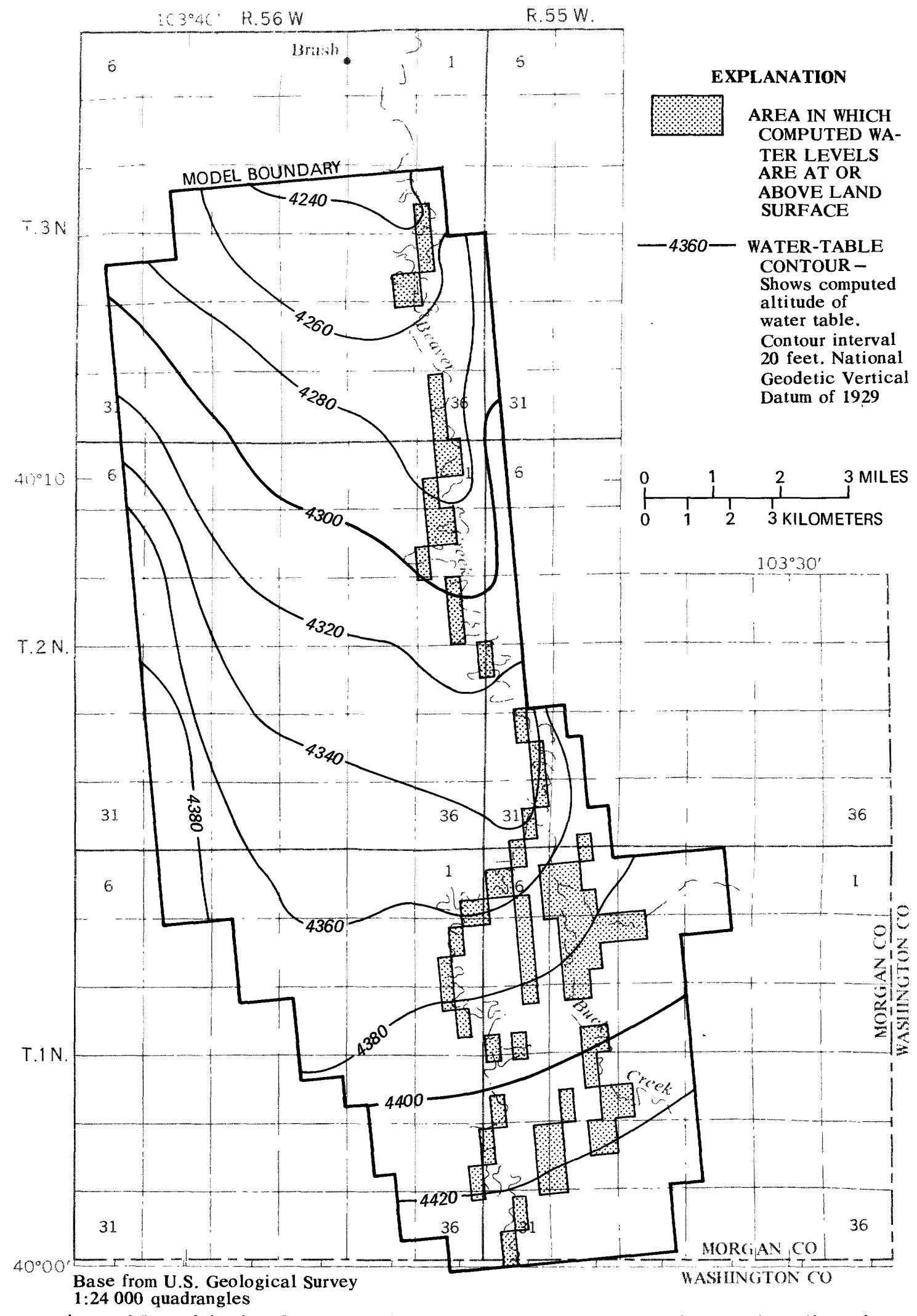

Figure 35.-- Altitude of water table computed by the model using median-diversion recharge with estimated current pumping, Beaver Creek valley. 




Figure 36.-- Computed water levels for selected wells using median-diversion recharge with estimated current pumping, Beaver Creek valley. 
To compare the seasonal water-level changes to the long-term water-level changes, a simulation was made with monthly time intervals. The monthly recharge computed by the distribution model (table 5) for the median diversions using the canal configuration having all canals and 65 ponds was repeated for 27 years. The estimated current pumping was distributed monthly according to a typical potential evapotranspiration curve for this area (Hurr and others, 1975, fig. 11). The resulting net stress on the aquifer is shown in table 13. During the twenty-seventh year, water levels (table 13) were approximately at the same level as predicted by the annual time-increment simulation (fig. 36). Seasonal fluctuation ranged between 0.4 and $3.0 \mathrm{ft}$ at the $\mathrm{six}$ wells monitored during simulation. The monthly streamflow in Beaver Creek (table 13) ranged from $4.8 \mathrm{ft}^{3} / \mathrm{s}$ in September to $15.0 \mathrm{ft}^{3} / \mathrm{s}$ in April. The average of these monthly streamflow values corresponds closely to the streamflow for the twenty-seventh year with the simulation using the annual time intervals, although both values are noticeably less than the final steadystate values (table 12).

The effects of recharge greater than that occurring with median diversions were simulated using the 27 years of historically developed data (table 9). Using the same monthly time interval and estimated monthly pumping as the previous simulation, monthly recharge computed by the canal-distribution model was input into the ground-water model for 27 years. The net stress (artificial recharge less pumping) for the 27 years is shown in figure 37. The response of the aquifer system, indicated in figures 38-41, is compared to the responses when simulated with median-diversion recharge. Although the canal-distribution model indicated no problems in soil infiltration during the 27 years of historically developed diversions, the ground-water model did. Through the first 10 years of simulation there are intermittent periods in which water levels in the sand hill areas approach land surface. The large recharge during the eleventh year, however, raises water levels throughout the sand hill areas above land surface (recall that the recharge values computed by the canal-distribution model and evapotranspiration rates are not modified by the ground-water model as areas become waterlogged). Throughout the remainder of the 27-year simulation period, most of the sand hill area east of the recharge ditches has water levels above the land surface. 


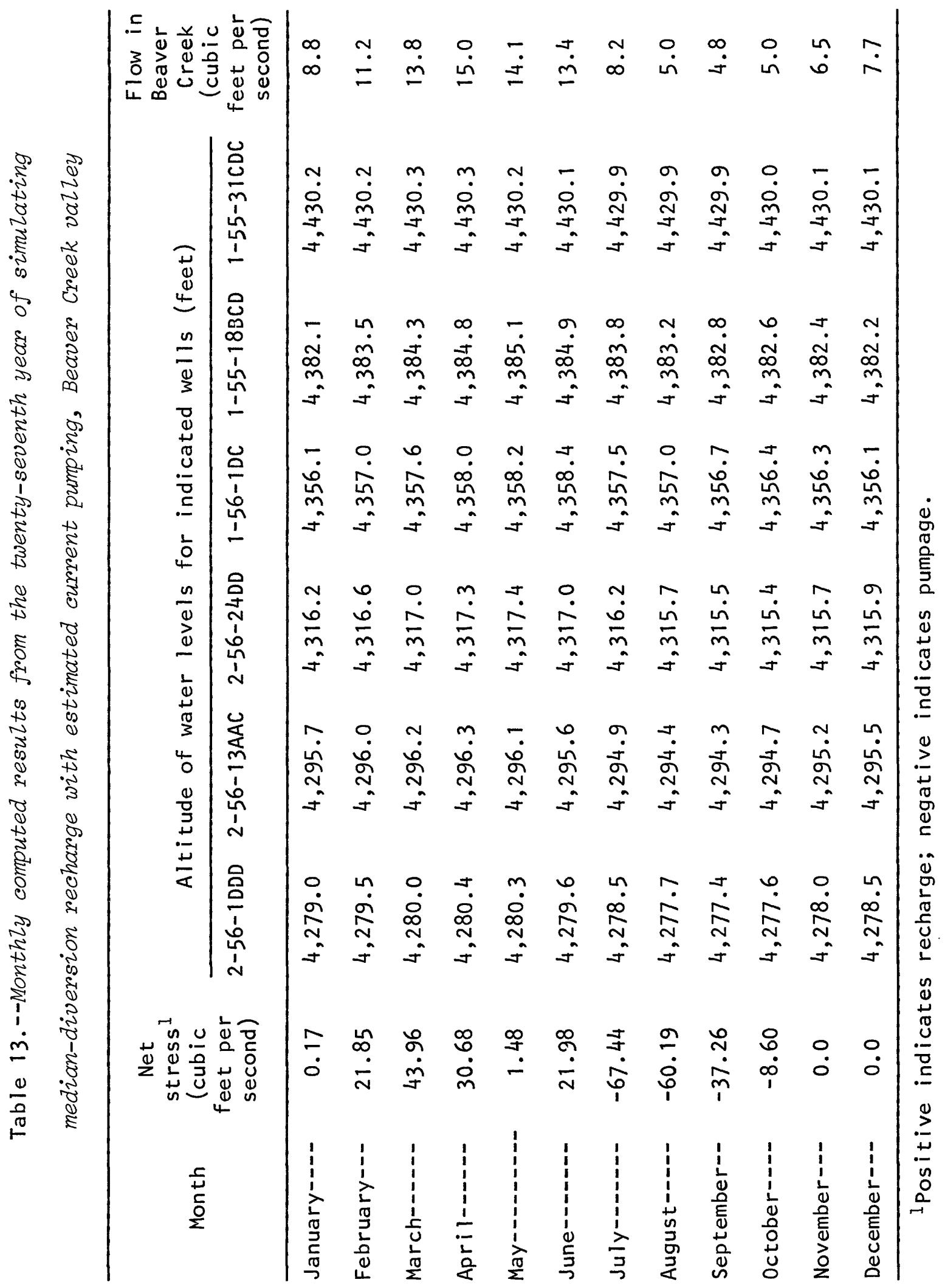




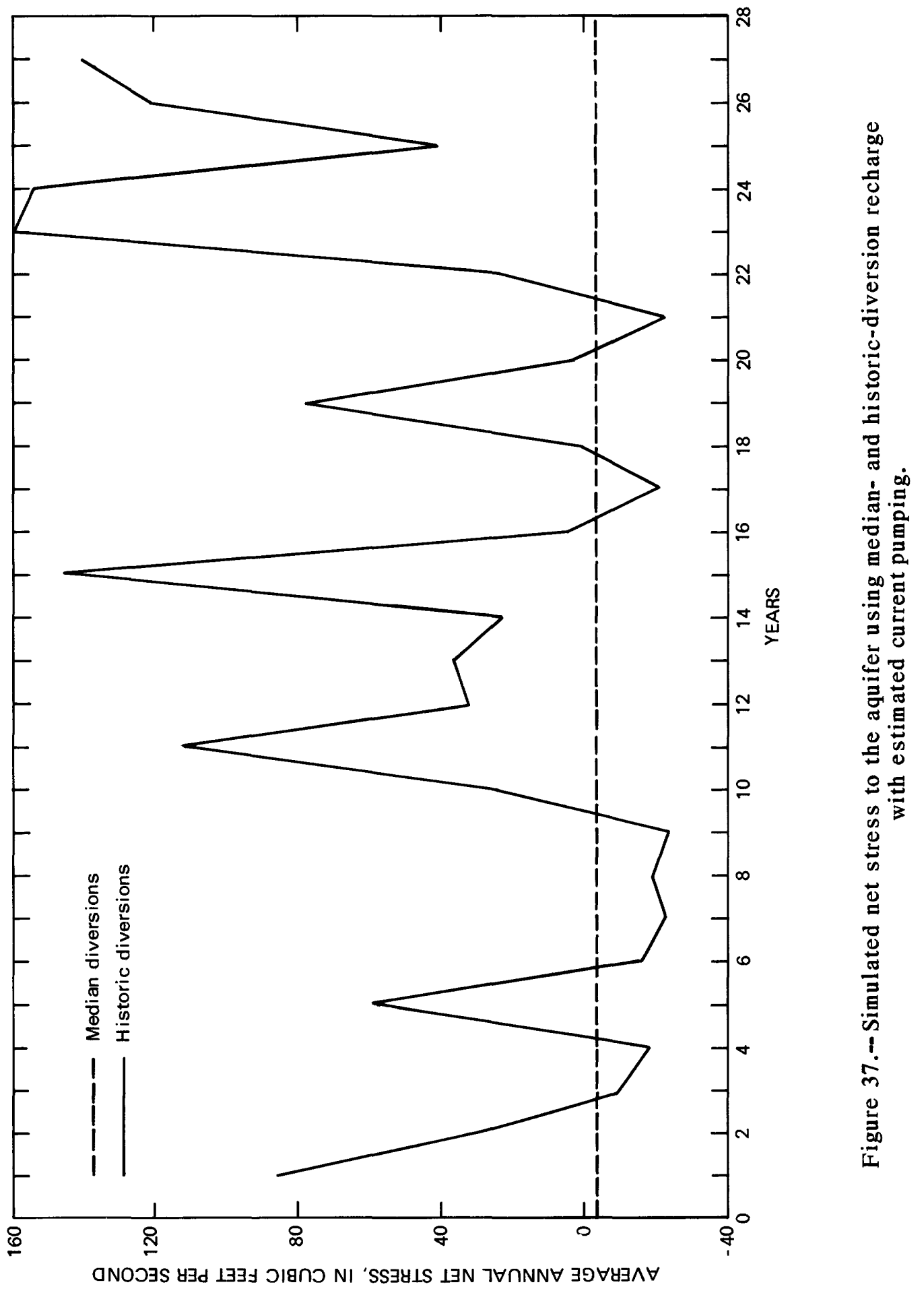




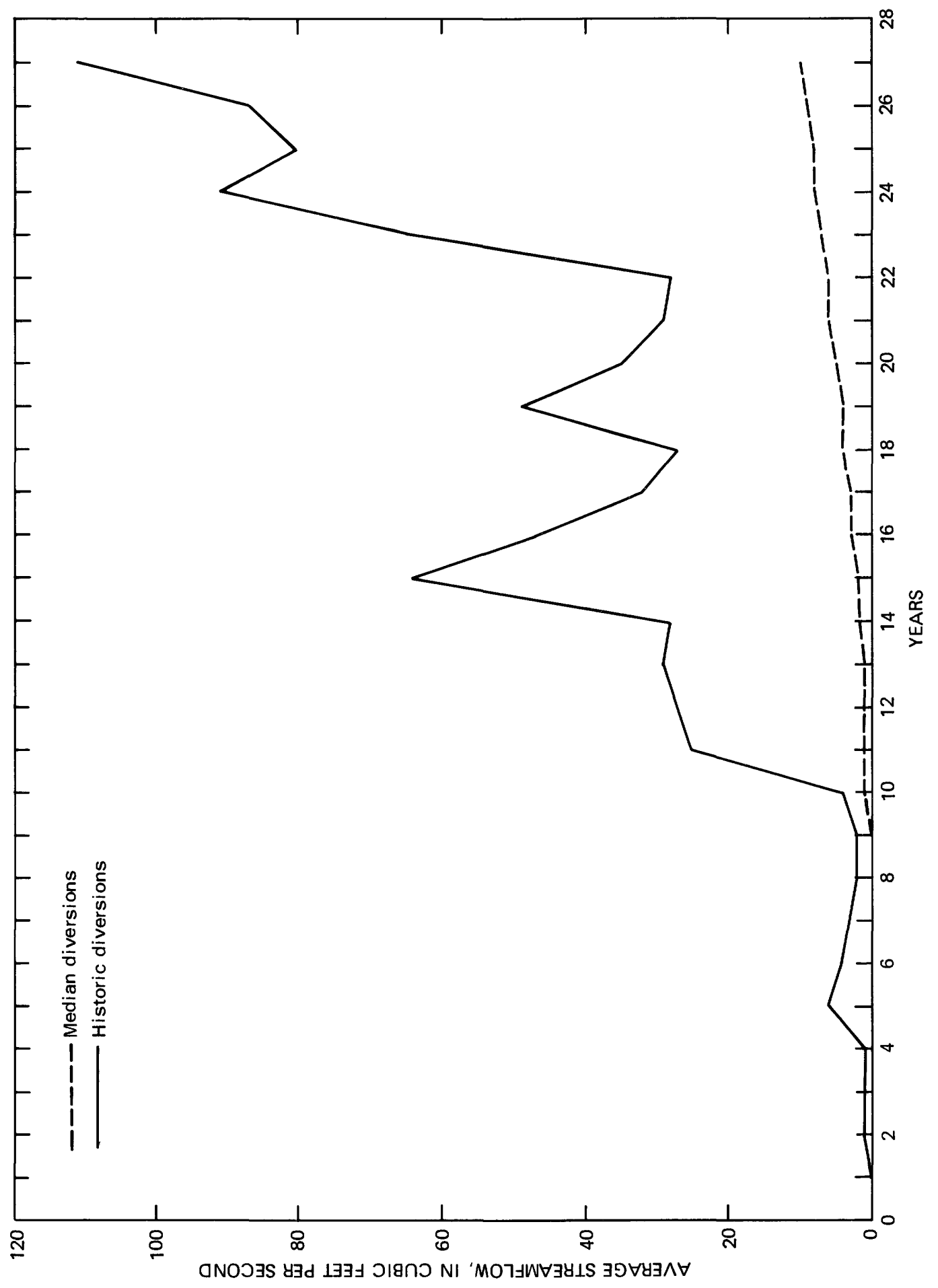

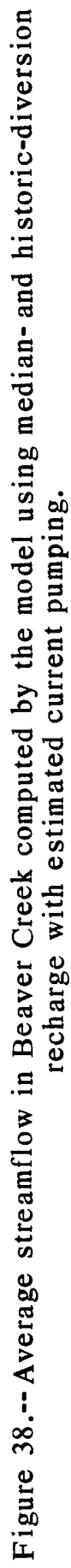




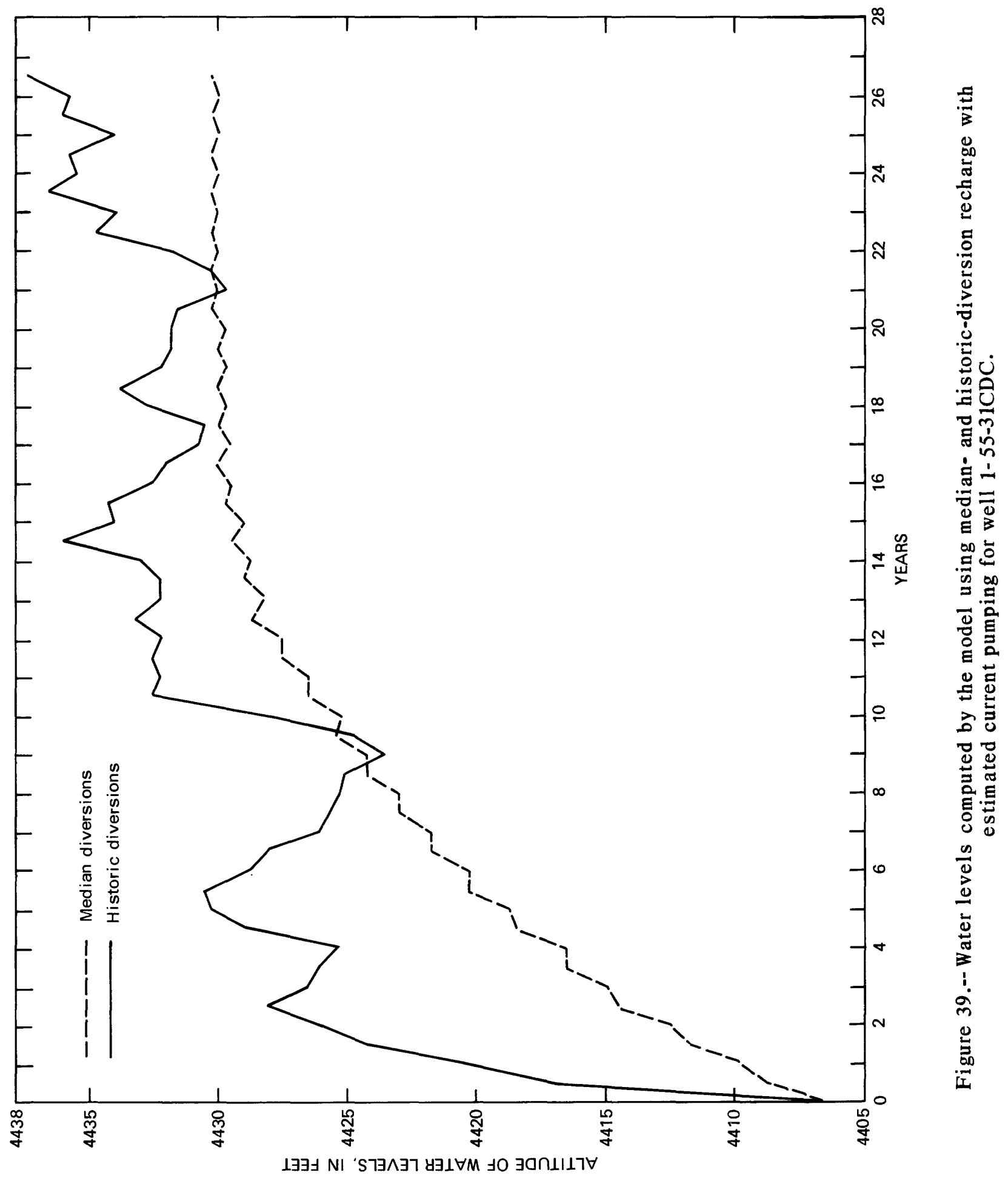




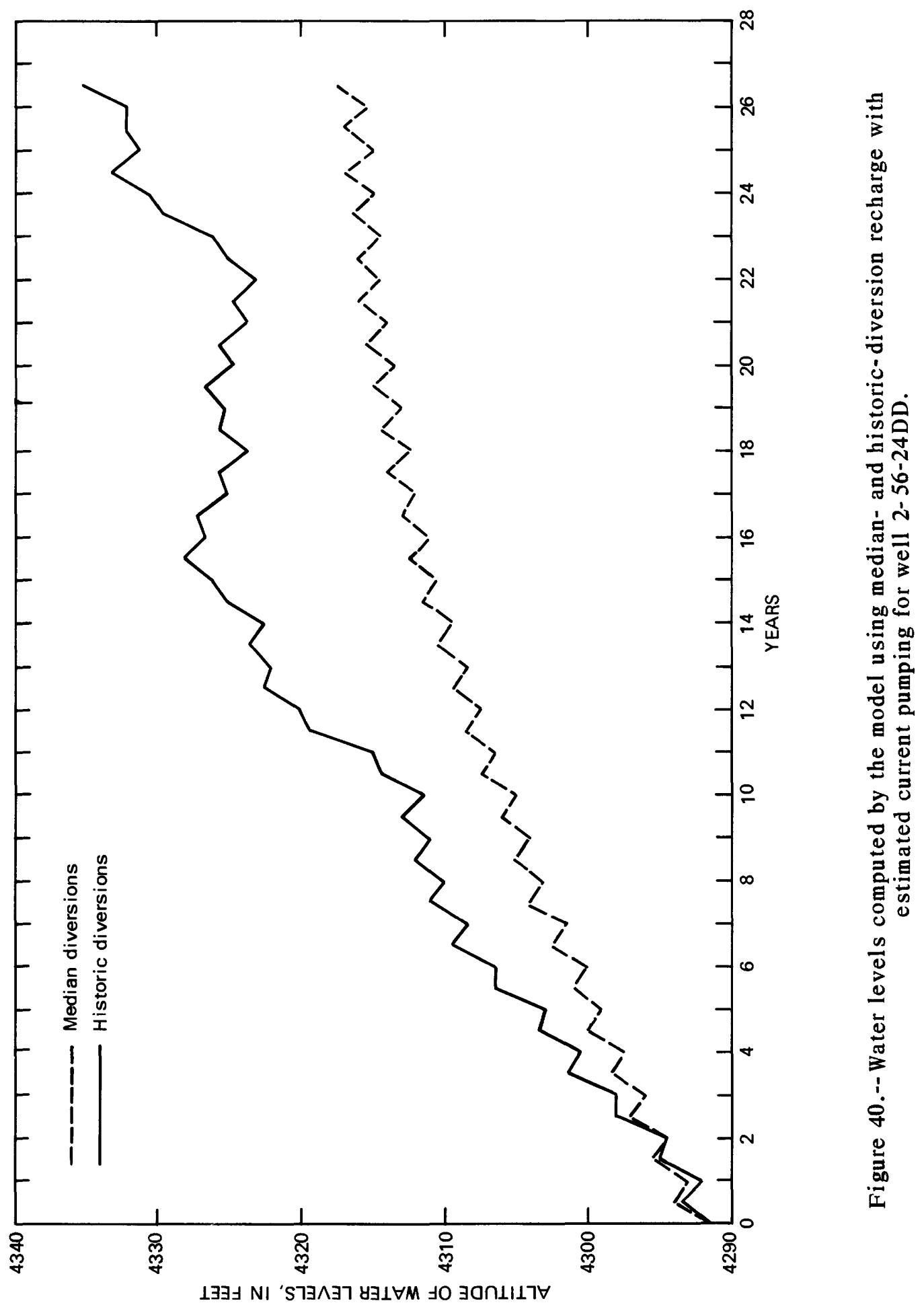







A second set of simulations was made from four of the five recharge configurations used previously but with increased pumping rates. The model computed the increased pumping linearly based on the increased saturated thickness during the first 10 years of simulation. Pumpage was extracted only in nodes already having some pumping capacity. Water budgets for each of these alternatives for the steady-state water-table conditions are shown in table 14. The computed pumping rate for each of these alternatives was about $32 \mathrm{ft}^{3} / \mathrm{s}$, or near the estimated maximum historic pumping (fig. 24). For each alternative, there are areas of continuous flow in Beaver Creek and no significant areas of waterlogging.

Table 14.--Water budgets computed by the model for four artificial-recharge configurations using median-diversion recharge with computed increased pumping, Beaver Creek valley

\begin{tabular}{lcccc}
\hline & $\begin{array}{c}\text { Entire canal } \\
\text { system with } \\
65 \text { ponds }\end{array}$ & $\begin{array}{c}\text { Beaver Creek } \\
\text { valley only }\end{array}$ & $\begin{array}{c}\text { Recharge } \\
\text { canals } \\
\text { only }\end{array}$ & $\begin{array}{c}\text { Recharge } \\
\text { canals plus } \\
\text { extension }\end{array}$ \\
\hline $\begin{array}{l}\text { Inflow: } \\
\text { Boundary flux-- }\end{array}$ & 23.1 & 23.1 & 23.1 & 23.1 \\
Recharge--1 feet per second & 19.2 \\
$\begin{array}{l}\text { Outflow: } \\
\text { Pumping-- }\end{array}$ & 19.4 & 28.5 & 18.5 & \\
Streamflow--- & 31.8 & 32.3 & 31.7 & 31.8 \\
Boundary flux-- & 8.5 & 17.1 & 7.7 & 8.3 \\
\hline
\end{tabular}

A final simulation run was made using the maximum pumping rate. This model run was similar to those just discussed except an arbitrary total of $40 \mathrm{ft}^{3} / \mathrm{s}$ pumping was simulated. This value was chosen with the artificialrecharge configuration of using all the canals with 65 ponds so that there would be only a minimal amount of excess water to supply streamflow (tables 12 and 14). Again the model computed the distribution of pumping constrained by increasing withdrawals only at those nodes that had some pumping capability. The water budget after 100 years of simulation (the system was still not quite at steady-state) is shown in table 15. The water-table surface after 100 years of simulation is shown in figure 42 . 


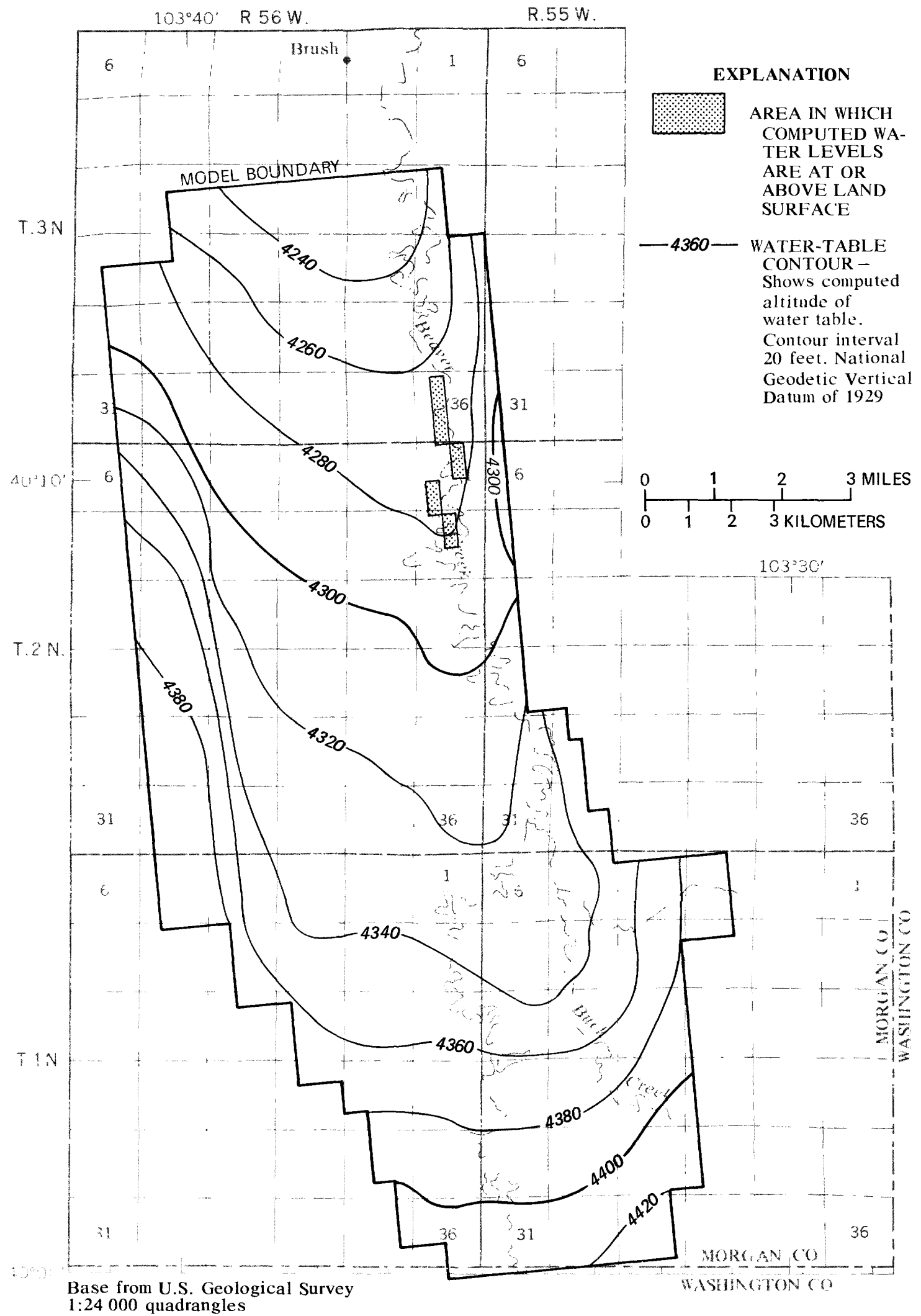

Figure 42.- Altitude of water table computed by the model using median-diversion recharge with computed maximum increased pumping. Beaver Creek valley. 
Table 15.--Water budget computed by the model using all canals, 65 ponds, median-diversion recharge, and maximum computed increased pumping, Beaver Creek valley



Predicted Conditions in Badger Creek Valley

A set of four different canal simulations corresponding to different configurations for recharge was simulated for the Badger Creek valley using the estimated current pumping. Because only net withdrawals are computed and because it was assumed that the Badger Creek system is currently at steadystate, any artificial recharge must result in rising water levels and eventually increased streamflow if pumping and the outflow boundary flux do not change. Water budgets for these four simulations are shown in table 16 . The predicted water-table surface for the canal configuration using all canals and 65 ponds is shown in figure 43. A significant area of potential waterlogging is predicted along parts of the delivery canal that any project design would have to account for, either by lining that part of the canal or by pumping ground water in that vicinity. This will occur even if the final design of the project were to recharge only in Beaver Creek valley because this part of the canal carries all of the diversion at this point.

One additional computer simulation was made for Badger Creek valley. Using the same canal configuration described above with the median-diversion recharge, pumping was increased from the estimated current level. The model computed the pumping as a function of increased saturated thickness due to the artificial recharge. The model was constrained to increase pumping only in those areas that were irrigated by wells as indicated on the water-rights list submitted by the Conservancy District ( $p .43)$. This insures that no areas under a surface-water ditch could increase pumping. The water budget for this simulation after 100 years (the system had not quite reached steadystate) is shown in table 17. The water-table configuration after 100 years is shown on figure 44 . 




Figure 43.-- Altitude of water table computed by the model using median-diversion recharge with estimated current pumping, Badger Creek valley. 
Table 16.--Water budgets computed by the model

for four artificial-recharge configurations using median-diversion recharge with estimated current pumping, Badger creek valley

\begin{tabular}{|c|c|c|c|c|}
\hline & $\begin{array}{c}\text { Entire canal } \\
\text { system with } \\
7 \text { ponds }\end{array}$ & $\begin{array}{l}\text { Entire canal } \\
\text { system with } \\
65 \text { ponds }\end{array}$ & $\begin{array}{l}\text { Badger Creek } \\
\text { valley only }\end{array}$ & $\begin{array}{c}\text { Recharge } \\
\text { canals } \\
\text { only }\end{array}$ \\
\hline & & Cubic feet & per second & \\
\hline \multicolumn{5}{|l|}{ Inflow: } \\
\hline Boundary flux- & 17.1 & 17.1 & 17.1 & 17.1 \\
\hline Recharge--and- & 12.9 & 13.4 & 32.7 & 14.1 \\
\hline \multicolumn{5}{|l|}{ Outf low: } \\
\hline Pump ing- & 8.6 & 8.6 & 8.6 & 8.6 \\
\hline Streamflow- & 12.9 & 13.4 & 32.7 & 14.1 \\
\hline Boundary flux- & 8.5 & 8.5 & 8.5 & 8.5 \\
\hline
\end{tabular}

Table 17.--Water budget computed by the model using all canals, 65 ponds, median-diversion recharge, and increased pumping, Badger Creek valley

Inflow:

Cubic feet

per second

$\begin{array}{lr}\text { Boundary flux- } & 17.1 \\ \text { Recharge- } & 13.4 \\ \text { Ground-water storage--- } & 0.2\end{array}$

Outflow:

Pump ing-- $\quad 17.5$

Streamflow-- 4.7

Boundary flux-- 8.5 


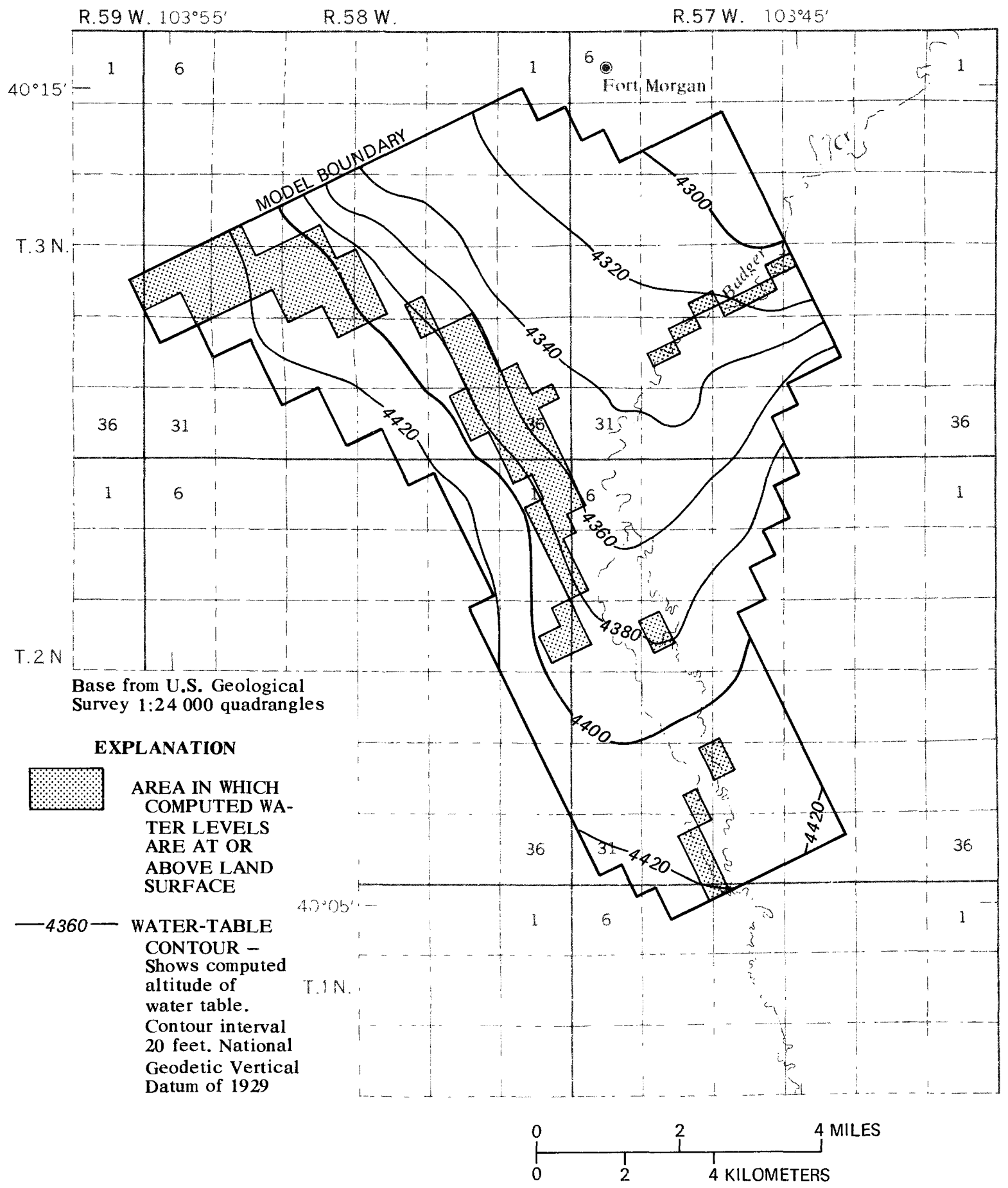

Figure 44.-- Altitude of water table computed by the model using median-diversion recharge with increased pumping, Badger Creek valley. 
The total impact of the proposed project on the South Platte River basin must be determined so that the local benefits of the project can be weighed against the possible regional adverse effects. The water in the river is of extreme importance not only for its economic value as a source of irrigation, but also for its environmental value, including maintainance of fish, wildlife, and waterfowl habitats.

The steady-state effects of this project on the river downstream from the study area would be minimal. All of the water that would seep from the canals before they reached the alluvial valleys would recharge the South Platte River alluvial aquifer and thus, in a steady-state analysis, would not constitute any loss from the total system. Most of the water that would recharge the two alluvial aquifers along the creeks would fulfill needs for ground-water withdrawals or become streamflow that would return to the South Platte River. The only losses of water would be evaporation from the ponds and any increase in consumptive use by crops. Assuming pumping is increased to $32 \mathrm{ft}^{3} / \mathrm{s}$ in Beaver Creek valley and to $17 \mathrm{ft}^{3} / \mathrm{s}$ in Badger Creek valley, an increase of about 13,000 acre-ft per year would be used by crops.

Time required to reach this assumed steady-state condition is difficult to estimate. The existing Bijou Canal is about $40 \mathrm{mi}$ long and parallels the river at distances of about 1 to $6 \mathrm{mi}$. Using a technique to estimate stream depletion due to pumping from wells (Jenkins, 1970), the rate of ground-water return flow to the river can be computed as a percentage of the steady recharge from the canal leakage. Assuming an average distance from the canal to the river of $4 \mathrm{mi}$ and an average transmissivity of the aquifer of about $30,000 \mathrm{ft}^{2} / \mathrm{d}$ (Hurr and others, 1972b), the ground-water return flow to the river will be 50 percent of the canal leakage in about 10 years, 70 percent in about 29 years, and 90 percent in about 400 years. Water recharged into the two alluvial aquifers will eventually reach the creek channels and be transported back to the river through surface-water channels in a matter of weeks. The time before the recharged water becomes streamflow can be estimated from figure 38. About $8 \mathrm{ft}^{3} / \mathrm{s}$ (or one-half of the steady-state flow of $16.3 \mathrm{ft}^{3} / \mathrm{s}$ ) was flowing in Beaver Creek after 25 years. The aquifer system requires about 60 years to reach steady-state. Using the results from the simulation with the increased pumping rates shown in table 14, the model shows that about 100 years are needed to reach steady-state. An estimate of the timing of the total project impact, using the median-diversion inflow, is shown in table 18 .

These estimates of the timing for the return flows are not very precise. To try to determine the effects of the diversions using stochastic streamflow values, another model was used. A stream-aquifer model of the South Platte River basin from Henderson (just north of Denver) to Julesburg (Colorado-Nebraska State line) is available (R. T. Hurr and A. W. Burns, U.S. Geological Survey, written commun., 1979; A. W. Burns, U.S. Geological Survey, unpublished data, 1979). This digital-computer model simulates the water-management activities of all the irrigation systems in the basin. The water-right 
Table 18.--Water budget of changes in the South Platte River basin due to the artificial-recharge project

\begin{tabular}{ccccc}
\hline Years Diversion & $\begin{array}{c}\text { Increase in } \\
\text { consumptive } \\
\text { use }\end{array}$ & $\begin{array}{c}\text { Increase in } \\
\text { ground water } \\
\text { in storage }\end{array}$ & $\begin{array}{c}\text { Increase in } \\
\text { ground-water flow } \\
\text { to the river }\end{array}$ \\
$1--$ & 43,000 & 13,000 & 29,000 & 1,000 \\
$10-$ & 43,000 & 13,000 & 18,000 & 12,000 \\
$100--$ & 43,000 & 13,000 & 4,000 & 26,000 \\
\hline
\end{tabular}

system is input to the model, and by trying to meet a designated demand for irrigation, water is diverted from the river, diverted from reservoir storage, or pumped from ground water for all the canals in the basin. The effect of each stress, whether it be recharge due to applications of water or pumping, is computed to determine the effect on the flow of the river. For this study, the model was modified to allow streamflow to be diverted into canals from which water can seep into the aquifer, either directly or from associated spreading ponds. The model was also modified to compute tributary inflow as a function of increasing ground-water storage; this made possible the simulation of flowing streams at Beaver and Badger Creeks. This was an empirical formulation with regression parameters based on matching the streamflow in Beaver Creek computed by the ground-water model (fig. 38).

Three simulation runs were made with this model using inflow data from 1951 to 1974. The first simulation, used for control, was designed to compare with later simulation results. For this simulation, pumping within the Badger and Beaver Water Conservancy District was simulated at an average of about 31,000 acre-ft per year. The second simulation assumed the construction of the artificial-recharge project. The introduction of a new water-resource activity within the water-managment system of the South Platte River basin affected almost every other ditch system. Because diversions for the project took place during nonirrigation season and some of the return flows entered the river during the irrigation season, total basin surface-water diversions for direct applications increased. This in turn resulted in a decrease of ground-water withdrawals. The total mass balance computed by the model (which 
includes about 30 components) maintained a conservation of mass. The more important components listed in this discussion do not reflect the total mass balance. The model computed an average diversion of 88,000 acre-ft per year for the 24 years. In the model, the entire diversion contributed directly to recharge of the ground-water system, through either canal or pond leakage. The impact of that recharge accounted for most of the increased ground-water flow to the river $(65,000$ acre-ft per year) and increased volume in storage (34,000 acre-ft per year). Although this simulation resulted in an average decrease in streamflow of the South Platte River from the modeled area of 34,000 acre-ft per year, the streamflow was augmented during the irrigation season downstream from the recharge site. This made possible an overall increase in surface-water applications of about 9,000 acre-ft per year which in turn caused a decrease of 13,000 acre-ft per year in ground-water pumping.

The final simulation run with the stream-aquifer model was for the same inflow conditions and with the artificial-recharge project, but with pumping within the project area increased about 60 percent. For this simulation, most of the 85,000 acre-ft per year average diversion can be accounted for in the basinwide mass balance as: (1) Increased pumping, 12,000 acre-ft per year; (2) increased ground-water flow to the river, 42,000 acre-ft per year; and (3) increased ground-water storage, 26,000 acre-ft per year. The net streamflow loss in the South Platte River was about 42,000 acre-ft per year, but the flows caused by the recharge in Beaver and Badger Creeks improved irrigation-season diversions.

\section{SUMMARY}

The Badger and Beaver Water Conservancy District was formed in 1976 to promote an artificial-recharge project in the alluvial valleys of Badger and Beaver Creeks in Morgan County, Colo. The preliminary proposal was to divert water from the South Platte River through the existing Bijou Canal, to transport the water to the upper end of these two valleys, and to direct water through ditches and into ponds to recharge the underlying alluvial aquifers. The purpose of this recharge was to restore the water levels in these tributary valleys so that pumping for irrigation could return to its previous larger rates.

The first item considered in the hydrologic anaiysis of the proposed project was the availability of streamflow for diversion. In order to consider the effects of all senior water rights, data developed by the U.S. Bureau of Reclamation for the storable flows into the proposed Narrows Reservoir were used. These data indicated that the average storable flow for the 9 months (October through June) was 217,000 acre-ft. However, because of the limited capacity of Bijou Canal, only an average of 96,000 acre-ft per year could be diverted. The distribution of this flow, in time, is quite variable and for much of this study, the median-divertible flow of 43,000 acre-ft per year was used. 
Water is to be diverted at the headgate of Bijou Canal and transported to new canals to be constructed as part of the proposed project. The water would be allowed to seep from these canals or be diverted into ponds or stream channels to recharge the underlying alluvial aquifers. If the 43,000 acre-ft were diverted annually, leakage from the existing canal would be 19,000 acre-ft, leakage into Badger Creek valley would be 10,000 acre-ft, and leakage into Beaver Creek valley would be 14,000 acre-ft, assuming a canal configuration using all proposed canals and 65 ponds. This inflow condition results in ponds having water 5 months of the year with a maximum surface area of 304 acres. Historically developed diversions averaged 96,000 acre-ft per year and ranged from a low of 4,000 acre-ft per year to a high of 244,000 acre-ft per year. Using this inflow condition in the simulation, the pond 1 ife averaged 5.4 months per year and the average pond surface area was 321 acres with a median maximum monthly surface area of 1,249 acres.

The diversion of 43,000 acre-ft per year would provide ample recharge to the two alluvial-aquifer systems. Waterlogging would be a problem only along the west side of Badger Creek valley. Water levels would rise slightly and create flowing streams in the channels of both Beaver and Badger Creeks. An increase in current pumping rates by 50 percent would cause no drawdown problems on a regional basis. However, if the maximum available water was diverted and recharged, it appears that the aquifer systems would be flooded and could not transmit the water to the stream channels or irrigation wells fast enough to avoid total waterlogging of the recharge areas in the sand hills.

The total hydrologic impact of the artificial-recharge proposal would be minimal after steady-state conditions were achieved--the only significant losses to the South Platte River basin would be the increased pumping for the renewed irrigation. However, the time before the systems would reach steadystate is on the order of decades, and the initial impact of the proposed project would need to be considered as a total loss of the annual diversions. 


\section{REFERENCES}

Abiodun, A. A., 1973, Analysis of seepage into ground-water systems: Journal of the Hydraulics Division of the American Society of Civil Engineers, May 1972, p. 779-785.

Bittinger, M. W., and others, 1979, Impact of irrigation efficiency improvements on water availability in the South Platte River basin: Colorado Water Resources Research Institute, Environmental Resources Center Technical Report No. 13, 96 p.

Bjorklund, L. J., and Brown, R. F., 1957, Geology and ground-water resources of the lower South Platte River valley between Hardin, Colorado and Paxton, Nebraska: U.S. Geological Survey Water-Supply Paper 1378, 431 p.

Bouwer, Herman, 1965, Theoretical aspects of seepage from open channels: Journal of the Hydraulics Division of the American Society of Civil Engineers, May 1965, p. 37-59.

Bouwer, Herman, Myers, L. E., and Rice, R. C., 1962, Effect of velocity on seepage and its measurement: Journal of the Irrigation and Drainage Division of the American Society of Civil Engineers, September 1962, p. $1-14$.

Chow, V. T., 1959, Open-channel hydraulics: McGraw-Hill Book Company, 680 p. Code, W. E., 1943, Use of ground water for irrigation in the South Platte Valley of Colorado: Colorado Agricultural Experiment Station Bulle$\operatorname{tin} 483,44 \mathrm{p}$.

1945, Ground-water supply of Prospect Valley, Colorado: Colorado Agricultural Experiment Station Technical Bulletin 54.

Emmons, P. J., 1977, Artificial-recharge tests in Upper Black Squirrel Creek basin, Jimmy Camp Valley, and Fountain Valley, El Paso County, Colorado: U.S. Geological Survey Water-Resources Investigations 77-11, $49 \mathrm{p}$.

Garg, S. P., and Chawla, A. S., 1970, Seepage from trapezoidal channels: Journal of the Hydraulics Division of the American Society of Civil Engineers, June 1970, p. 1261-1281.

Hunt, B. W., 1972, Seepage from shallow open channels: Journal of the Hydraulics Division of the American Society of Civil Engineers, May 1972, p. 779-785.

Hurr, R. T., Schneider, P. A., Jr., and others, 1972a, Hydrogeologic characteristics of the valley-fill aquifer in the Brush reach of the South Platte River valley, northeastern Colorado: U.S. Geological Survey open-file report, 4 p., 6 pls.

1972b, Hydrogeologic characteristics of the valley-fill aquifer in the Weldona reach of the South Platte River valley, Colorado: U.S. Geological Survey open-file report, 4 p., 6 pls.

Hurr, R. T., Schneider, P. A., Jr., and Minges, D. R., 1975, Hydrology of the South Platte River valley, northeastern Colorado: Colorado Water-Resources Circular 28,24 p., 5 pls.

Jenkins, C. T., 1970, Computation of rate and volume of stream depletion by wells: U.S. Geological Survey Techniques of Water-Resources Investigations, Book 4, Chapter D1, 17 p.

Lappala, E. R., 1978, Quantitative hydrogeology of the Upper Republican Natural Resources District, southwest Nebraska: U.S. Geological Survey Water-Resources Investigations 78-38, $200 \mathrm{p}$. 
McGovern, H. E., 1964, Geology and ground-water resources of Washington County, Colorado: U.S. Geological Survey Water-Supply Paper 1777.

Morel-Seytoux, H. J., 1964, Domain variations in channel seepage flow: Journal of the Hydraulics Division of the American Society of Civil Engineers, March 1964, p. 55-78.

Parshall, R. L., 1922, Return of seepage water to the lower South Platte River in Colorado: Colorado Agricultural Experiment Station Bulletin 279, $72 \mathrm{p}$.

Prill, R. C., 1977, Movement of moisture in the unsaturated zone in a loessmantled area, southwestern Kansas: U.S. Geological Survey Professional Paper 1021, 21 p.

Robinson, A. R., and Rohwer, Carl, 1957, Measurement of canal seepage: Transactions of the American Society of Civil Engineers, v. 152, p. 347373.

Schiff, Leonard, 1953, The effect of surface head on infiltration rates based on the performance of ring infiltrometers and ponds: Transactions of the American Geophysical Union, April 1953, p. 257-266.

Skinner, M. M., 1963, Artificial ground-water recharge in the Prospect Valley area, Colorado: Colorado Agricultural Experiment Station Bulletin 792, $89 \mathrm{p}$.

Taylor, 0. J., 1975, Artificial-recharge experiments in the alluvial aquifer south of Fountain, El Paso County, Colorado: Colorado Water Resources Circular 31,28 p.

Terstriep, M. L., and Stall, J. B., 1974, The Illinois Urban Drainage Area Simulator, ILLUDAS: Illinois State Water Survey Bulletin 58.

Trescott, P. C., Pinder, G. F., and Larson, S. P., 1976, Finite-difference model for aquifer simulation in two dimensions with results of numerical experiments: U.S. Geological Survey Techniques of Water-Resources Investigations, Book 7, Chapter $\mathrm{C} 1,116 \mathrm{p}$.

U.S. Bureau of Reclamation, 1965, Historic river operation study-recorded and computed flow: Missouri River Basin Project, Narrows Unit, computer printout.

U.S. Department of Agriculture, 1968, Soil survey of Morgan County, Colorado: Soil Conservation Service, 102 p. 1972, Land use map, Morgan County, Colorado: Soil Conservation Service, $1 \mathrm{pl}$.

Worstell, R. V., 1976, Estimating seepage losses from canal systems: Journal of the Irrigation and Drainage Division of the American Society of Civil Engineers, March 1976, p. 137-147. 
SUPPLEMENTAL INFORMATION 

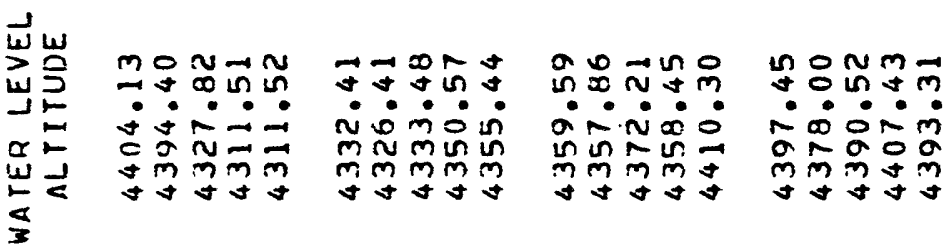

$m m \infty$ - $\bullet \cdot$ $0+1005$ $\alpha=0$ $m \rightarrow t m m$

$m \rightarrow 0 N N$ omm i $\dot{1} \dot{1} \dot{0}$ - $N$ N $m m m m$ $\pi \tan 2$ in? - in m N $m m$ $9 \%$

$\infty$

os

4

की

$\frac{\pi}{2}$

4

1 a a Nmo


- 000 in $0 \leqslant 5$ $\pi+a \ln 0$ t 1 Un a் $\dot{0} \dot{0}$ 征然 nom no 0 in a $2 \pi$
- N N in $0 \mathrm{mo}$ in in: ntm in $\sim a+\infty \infty$ $0000 \mathrm{~m}$ in $\dot{0} \dot{0} \div$

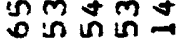

N $n$ DO ain mo in

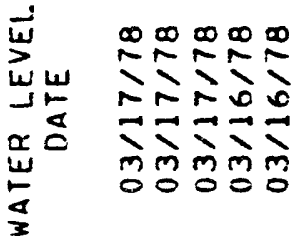

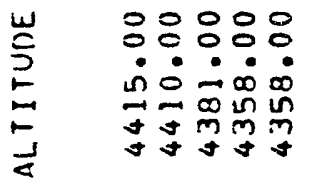

$\overrightarrow{0} \overrightarrow{0} \overrightarrow{0} \overrightarrow{0}$ 0 in n $N$ n 向前焉 $m m m m$

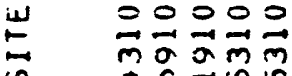
on $\tan$ in t 잉ㅇㅇ



$\infty \infty \infty \infty \infty$ जो min ले लाखे $\checkmark F=5$ लिखिए $\infty \infty \infty \infty \infty$


in in 0 m in $\checkmark=-1$ ले mले

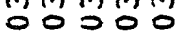

$\infty \infty \infty \infty \infty$

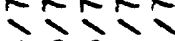
4 n 45 $\vec{\nabla} \vec{\nabla}$ $m m m m$

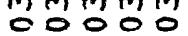

$\infty \infty \infty \infty \infty$ NTN $5 \div 00$ $\forall \rightarrow \vec{\nabla}$ ऐे̀े mे

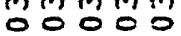

$\infty \infty \infty \infty \infty$ $\sim \sim \infty$ เे

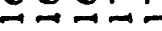
خो

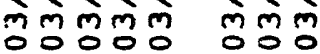

$\infty \infty \infty$

$N N$ $>10$ No $\sum_{m}$ 000


- i : a 000 $m \mathrm{~m}+5$ $\operatorname{mis}^{*}$

$\overrightarrow{0} \overrightarrow{0} \overrightarrow{0} \overrightarrow{0}$ กN 0 o in in mo n $m+4$ $m m m m m$ 00000 $\overrightarrow{0}=\vec{m} \vec{N}$ $0 \rightarrow 0+5$ * $t$ N 00000 응응응 4
0
0
응ㅇㅇㅇㅇㅇ $\therefore \dot{0} \dot{0}$ $00=5$

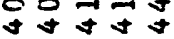

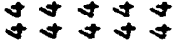

$\overrightarrow{0} \mathbb{0}=\overrightarrow{0}$ un $=0$ a in in $\rightarrow$ in $\lim =$ $m \mathrm{~m} m \bar{m}$ $m \mathrm{mmm}$ 00000 $\vec{\nabla} \vec{\sim} \overrightarrow{0} \overrightarrow{0}$ $\Rightarrow=$ ก 1 in N $⿻-1$ O 0000 웡
응ㅇㅇㅇㅇㅇㅇ - i \% ñu

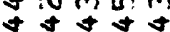

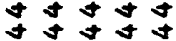

무유유 a $=\mathrm{M}$ O Nmor $n+t$ un $m m m m$ $m m m m m$

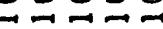
mon- N InOm 궁ㅇㅇ - 0000 연연
응응ㅇㅇㅇㅇㅇㅇ is in in in 0 in 0 o $4 \pm m m$ $\checkmark t+m m$

atad

$\overrightarrow{0} \overrightarrow{0} \overrightarrow{0} \overrightarrow{0}$ 에 000 $n-\forall m o$ $m \widetilde{m} \tilde{m}$ $m m m m m$ mूo $\vec{y} \overrightarrow{0} \overrightarrow{0} \vec{m}$ ton in in $000 \%$ 00000 00000 4 0 4
응웅ㅇㅇㅇㅇㅇ $\therefore$ 부웅 $\alpha \pi N x$ m $m$ m

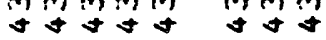

$\overrightarrow{0} \overrightarrow{0} \overrightarrow{0} \overrightarrow{0} \overrightarrow{0}$ $+\infty 0 \infty 1$ c n 0 in 0 $m \mathrm{~mm}$ $m m m m$ m $\vec{m} \vec{b} \vec{\square} \vec{\sigma}$ m n m in t t t in c0000 00000 a t
000 $\therefore \sim$ $\sim x$ m

$-100$ m N in on in $\infty$ in $m m m$ $m 00$ $\vec{N} \overrightarrow{0} \vec{a}$ $m$ in un $m$ 잉이 49



m

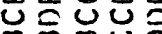
車禹这 ○。 00 nin in in in un in ०0000 00000 뭉ㅇㅇㅇㅇㅇㅇㅇㅇ and

똥ํㅇㅇํㅇ

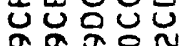
$\vec{n} \vec{n} \tilde{N}$

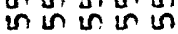
00000 뭉ㅎㅇ응 응ㅇㅇㅇㅇㅇㅇ

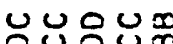
넌넌 - 0013 Nmm in in un กำ แn un 00000 무엉ㅎㅇ웅

4000 
Шు山

w与

U.

$\alpha=$ inmãa

W. mmmm

54

3

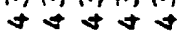

$x+\quad n \infty N \ln$

w. $0 \pm \infty \mathrm{N}=$

$8 w$

$-m i \dot{0}$

ก m원혀

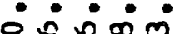

$a \infty \sigma \pm m$ $m m m s$

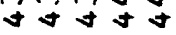

$N=0.0$ on 000 - i. :



กิ $\because \ddot{0}: \dot{0}$ $\infty \leq+\infty$ $\pm \pm m m$ $\sin$ $\infty \stackrel{0}{0}=0$ in $\wedge$ o 00

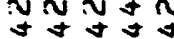

$m m N \infty$ ? $\therefore+a \div 0$ ง บง

$\alpha+a+\infty$ $\because n$ in $\infty$ in in: ms na $\sin \pm 0$ - $\cdot \cdot \cdot$ oa 020 $20 m 0=$

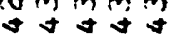

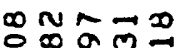


anOm० NOD

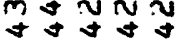

c. in $c \rightarrow 0$ anNON in: ñm
$N \propto m \sigma N$ $0 \sim 00 \infty$ $\dot{0} \dot{0} \dot{0}$ $m \stackrel{N}{N}$ U in 0

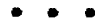
$\rightarrow 0=$ $\infty \vec{m}$ N

$0+0$ $\forall m n$ in $+m$



$\infty \infty \infty \infty \infty$ ㄷำ \pm \pm 는


लेंmm 00000 $\infty \infty \infty \infty \infty$ TN แก่ายั่

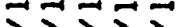
ले ले ले ऐेले

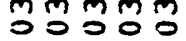

$\infty \infty \infty \infty \infty$ บบNN $00 \pi$ แn $\because-\vec{v}$ ओे गे गे गे ०0ㅇㅇ $\infty \infty \infty \infty \infty$ ㄷN ININ $\rightarrow \rightarrow-1 \rightarrow$ गे गेंगे

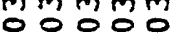

$\infty \infty \infty \infty \infty$ $N N N=N$ NNNM $\rightarrow 00$ 푸요 लm जे m $\infty \infty \infty$

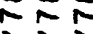
$2 \pm$ $\rightarrow=-$ mे $m$ ठ०

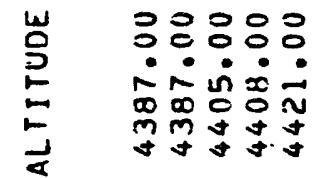


0 잉ㅇㅇ $00 \%$ in जो แn $m m m m$ อ以 은 300 ar $m$ in ำ m N N ㅇㅇㅇㅇㅇㅇ $\checkmark t+4$

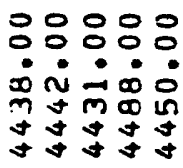

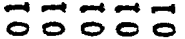
$+\ln \infty \frac{1}{m}$ 프뭉 $m \mathrm{~mm}$ $m \mathrm{~mm}$ 00000 a $\vec{N} \vec{m} \vec{v}$ $\forall$ ก


ㅇㅇㅇㅇㅇㅇ

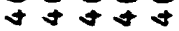

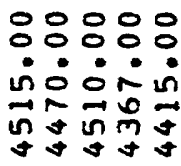

룽ㅁㅇㅇㅇㅁㅇ naaำ om $m$ in 잉 $\mathrm{m}$ $\mathrm{mm} \mathrm{mm}$ $m m m m$ $\rightarrow=10$ $\checkmark \sim 0 \times \infty$ unto no $\infty \infty \infty$ 잉ㅇㅇㅇ 4409
응웅ㅇㅇㅇ응 - $\dot{0} \dot{0}$ - nin $\vec{m} \vec{m} \dot{m}$ +

망루잉 in a $a \rightarrow n$ $+\forall+0$ $\forall \forall-4$ $m m m m$ $m m m m$ 0 o $\vec{N}=\overrightarrow{0}$ No $\rightarrow \pm m$ ๙ $\alpha$ N 00000 00000 4444
응잉ㅇㅇㅇㅇㅇㅇ응 i 0 i + $\forall$ un "ัे tog

웅뭉웅 on Na 0 mno no

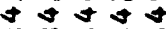
$m m m m$ $>0000$ $\overrightarrow{+} \vec{m} \overrightarrow{\mathrm{m}}$ N 1 ? ○ounu ㅇㅇㅇㅇㅇㅇㅇㅇㅇ $4+94$
잉ㅇㅇㅇㅇㅇㅇㅇㅇ - m $\infty 00$ * N N m

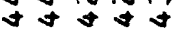

$\overrightarrow{0} \overrightarrow{0} \overrightarrow{0} \overrightarrow{0}$ O $+\infty$ mn in $N$ $N \rightarrow$ in in $N$ $m m m m m$ mmm o 00 Nㅡㄹ NNO in in 0 a 윽ㅇㅇㅇ 00000 $4+44$
웅용 웅 m. $m m$

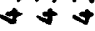

10 웅웅 $\checkmark$ in 0 a $a$ $m m m$ $m m m$ $0 \geq 0$ $+a \overline{0}$ $\rightarrow$ n $N$ 090 $\rightarrow 00$ 000 $\frac{1}{\frac{0}{0}}$

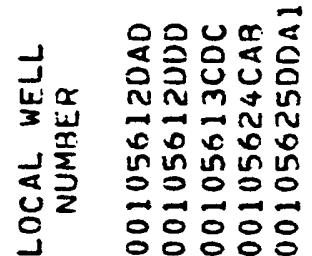

$\varangle m u$ 원엉


Nmooo ㄴํㄴ in in nn in in - N N N 잉ㅇㅇㅇ
우언 언? - In Un $\vec{n} \vec{n} \overrightarrow{\text { in }} \overrightarrow{\text { in }}$

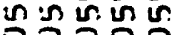
N 00000
눙ㅇ

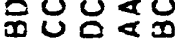
$\infty$ 我 $\vec{n} \vec{\sim}$ m in in in in N N N N 정ㅇㅇㅇㅇㅇㅇ

인 넝원응

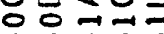
$m m m m$ nก in thin in in in in

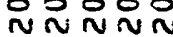




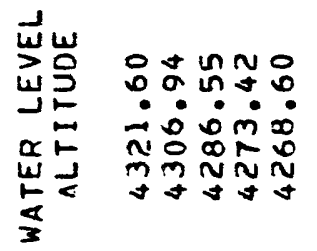

a의

O



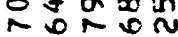
ปัง

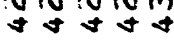

Ju

- 0 un 0 *0ษ 约 ம் ㅁNㅆㅇㅛ

$\rightarrow 0000$

a NR

$\because \dot{0} \dot{m}$

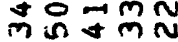

00000 ก i $\dot{0}$ in

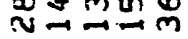

$\rightarrow \infty \rightarrow 0=$ $\because$ Oก *mi: agd

ON⿻0 - 0 n 0 in in $\begin{aligned} & 0 \\ & \text { n }\end{aligned}$ roun $\sim \infty \sim a$ i० $\rightarrow \sim$ o $\rightarrow n-1$ $m m m m$

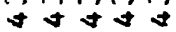

monnm nN $\ln 0$ ámin 约行 om

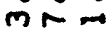
$m \cdot 0=$

$\infty \infty \infty \infty$ $-N-N$ $y>1.7$ $\pm \pm+\pi m$ ले लेखें

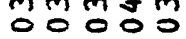

$\infty \infty \infty \pi$ NN $M N N G$ ज司焉 mm $m m$

00000

$\infty \infty \infty \infty \infty$ $\sim \sim-\infty$ परN Trar JVI mmmm 00000 $\infty \infty \infty \infty \infty$ $\checkmark N=N$ $00 N D N$ ज将 mmmm $\infty \infty \infty \infty \infty$ NNNN DNNDN $0= \pm=$ 기ำ mmmm $\infty \infty \infty \infty \infty$ NNN


1040

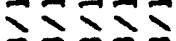
mmmm $\infty \infty \infty$

$\sim N N$ $2 \pm$ $=2$ ओे 000

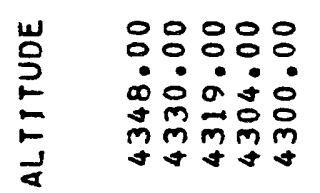

웅ㅇㅇㅇㅇㅇ in $\dot{0} \dot{0} \dot{0}$ 에요 $\prod_{j} m$ $\overrightarrow{0} \overrightarrow{0} \overrightarrow{0} \overrightarrow{0} \overrightarrow{0}$ ON anin ax $\infty$ in $m m m m m$ o00 00 $\overrightarrow{0} \vec{N} \vec{\nabla} \vec{N}$ in 0 in $-x$ x a $\alpha$


ㅇㅇㅇㅇㅇㅇㅇㅇㅇ a 494
뭉ㅎㅇ웅 - N N nis 0 m in in in in 0 $m m m m$ $0 \% 000$ $\overrightarrow{0} \overrightarrow{\vec{r}} \vec{m} \vec{N}$ O $\mathrm{m}$ in 1 a $\infty \infty$ 00000 응ㅇㅇㅇ응 \& $40 \%$
응영영영 ano in nan $m m m m$

$\overrightarrow{0} \overrightarrow{0} \overrightarrow{0} \overrightarrow{0}$ × M I

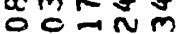
옹주 요의 m m mm 00000 $\vec{N} \vec{m} \vec{\square} \vec{m}$ $+m 0 \leq 0$ arR - 0000 연?
웅응ㅇㅇㅇㅇㅇㅇ - $\cdot$ in un $\mathrm{m}$ in mnnm $m m \mathrm{~mm}$ $y+y$ t

$\overrightarrow{0} \overrightarrow{0} \overrightarrow{0} \overrightarrow{0} \overrightarrow{0}$ $+0-6$ \& in oun in in in in un m.mm $m \dot{m}$ 00000 $\overrightarrow{\vec{A}} \overrightarrow{\mathrm{m}} \overrightarrow{\mathrm{m}}$ mMNOm NNRO 등응 응ㅇㅇㅇㅇㅇㅇㅇ



응옹영응 - i i





$\rightarrow \overrightarrow{0} \overrightarrow{0} \overrightarrow{0}$ M +Nmon in $\propto 0 \infty 0$ $m m \dot{m} m$ mm mm - 0000 जी $\vec{a} \vec{n} \vec{s}$ -Nomn 000 in - 0000 00000



응응옹응응 in $\dot{0}$ in: ○ 0 舟 m $m m$ $m m m m m m m g$

푸마 00000 $\infty \infty \mathrm{mam}$ in -0 in ñ $m \vec{m}+\vec{m}$ 00000 $\overrightarrow{0} \overrightarrow{0} \overrightarrow{10} \overrightarrow{4}$ - $0 \mathrm{~N}$ in no 0 \% 00000 80009
000 $\circ \div$ 웅응 $m m$ s $\rightarrow+5$

무웅 in $t m m$ ON $+4$ mm 응ㅇ $\exists \vec{a} 0$ $\checkmark N m$ $\infty \infty$ 000 웅 $\rightarrow$

บU

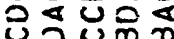
บั 0077 00000 แn แn un 응으응 NN N $N 0$
0
0


능뭉 Nm $m \leqslant$


in in un un ㅇํㅇㅇㅇㅇ กNกN 웅ㅇㅇㅇㅇㅇㅇ
๓யㅂㅇㅇㅇㅇㅇㅇㅇ

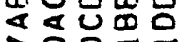
ㅇㅇㅇ문 00 c 0 in in in in in

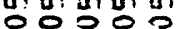
กำก

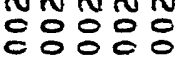

ㄴํ요 نU⿺廴寸 $m+t s$ in พ $N$ N 00060 in in in in 잉잉 NกNN 잉ㅇㅇㅇㅇㅇㅇ

ด บ 乌me 





mom $\checkmark r 0$ No 우웅 mots N N N N



a L

$<$ is ㄴ. in Mñ

ror $\rightarrow-0 N$ N.JN N mm
- 0 ino m N m n - a $\infty x$ Un N N N N N

$0 \pm 100$ - -1. $\dot{0} \dot{\sim} \dot{m}$ MN In

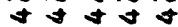

N $0 \div \div a$ - 0

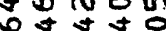
N $N$ N $+\forall t 5$

$m \pm 00$ an un $=$ $\circ \div \circ \circ$ n\&m on 000 * a N N

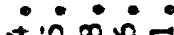
ina 0 N N N N $\rightarrow+5$ $0 \div 0$ in - in iño บNNNm t t t t t แn $\mathrm{N}$ un

000

N $\rightarrow$


000 $m m$

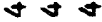

- noo $\rightarrow 0 \infty m$ aㅜㅎㅜ $+N+m$

in in $\infty$ in in o n 0 우 i் $\div \div \div$ $+\leqslant 0$ แn

$+N N$ $\sim \infty N$ $+0=$ $m \mathbf{N}$ $\infty \infty \infty \infty \infty$ NN ONNN $\rightarrow=\vec{F}$ ले ले लेले ०00ㅇ $\infty \infty \infty \infty \infty$ NNN $+ \pm \pm \pm N$ $\forall=-1=$ गेले ले

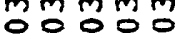

$\infty \infty \infty \infty \infty$ NNN \>1

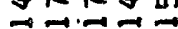

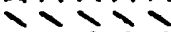
mฏm $\infty \infty \infty \infty \infty$ $\sim \sim N-N$ ถो जे เे जे जे $\rightarrow \rightarrow \rightarrow-$

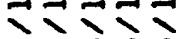
mm $\infty \infty \infty$ $\sim N N$ in in in $\checkmark=1$ mom
응ㅇㅇㅇㅇㅇㅇㅇㅇ

잉ㅇㅇ잉 - in: o nON Uñ g $q$ 4000 궁ㅇㅇ m $\vec{m} \vec{m}$

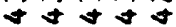

00000 00000 $\dot{0} \dot{0} \dot{0} \dot{0}$ $0 \infty \infty \infty$ $N N N \mathbb{N}$



응ㅇㅇㅇㅇㅇㅇ 00000


añ umm $m$ 000000 im ini $\because N M$ $\bar{m} m m$ $\checkmark t+5$

000 $.0 \%$ $+0=$ $+m m$ $m m m$

$\overrightarrow{0} \overrightarrow{0} \overrightarrow{0} \overrightarrow{0}$ n $m \infty \rightarrow a$ $\sim m m+t$

- $\quad a n g n$ $m m m m m$ $m m m m m$


№ ma UNก $\overrightarrow{0} \overrightarrow{0}=\overrightarrow{0}$ 00900

뭉ㄹㅇㅇㅠ $\operatorname{n}$ Un no $m=\pi$ min $\mathrm{mm}$ $m m m m$ 00000 $\vec{a} \vec{\forall} \vec{\sim} \vec{m}$ जित $m$ N $=7=$ 두잉 a 40


$n m$ nn $N$ n-mm coon m $\mathrm{mm} \mathrm{mm}$ 00000 on $\vec{n} \overrightarrow{0}$ $m \approx m m m$ $\rightarrow-\infty 0$


00000

$\overrightarrow{0} \overrightarrow{0} \overrightarrow{0} \overrightarrow{0}$ $\operatorname{tin} N \mathrm{n}$ o $0 \mathrm{mN}$ o $4 n N$ $m \& t+t$ ตอ $00 \%$ 00300 - 0 a 0 min $m$,


$\overrightarrow{0} \overrightarrow{0} \overrightarrow{0} \overrightarrow{0}$ \& 40

$\overrightarrow{0} \overrightarrow{0} \overrightarrow{0} \overrightarrow{0}$ in 0000 웅 atios

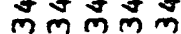
วอ잉 $\vec{I}=\vec{A} \overrightarrow{-1}$ non in $\mathrm{m} m \mathrm{~mm}$ 무잉 $40+5$

$\overrightarrow{0} \overrightarrow{0} \overrightarrow{0} \overrightarrow{0}$ 웅요웅 $\checkmark$ in in $\mathrm{m}$ in $0 \wedge \infty$ tง $\vec{a} \overrightarrow{0}=\overrightarrow{0}$ ar 000 N口n n⿺ m $m m$ m $\overrightarrow{0} \overrightarrow{0} \overrightarrow{0} \overrightarrow{0}$ $4+4$
000 $\rightarrow 01$ N $N$ in

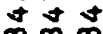
$0=0$ $\vec{m} \pm 0$ $\rightarrow \sim m$ NNN $\rightarrow \overrightarrow{0}=$ $\forall+4$

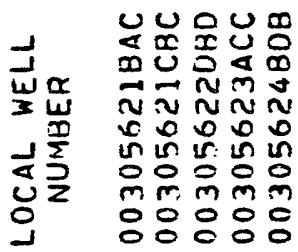

언으뭉

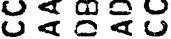
t nn in 0 NNNN 0000 แn แกแ แก 잉이잉 ○o잉
$00 \leq 0 \leq$ 넝응 a $\mathrm{a}$ N N แn แn แ 00000

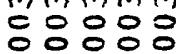

0 نu

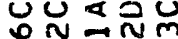
mo $\Rightarrow-1$ OR $R$ nnin in in 을응응

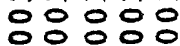

றU⿺⿻一𠃋


的 $\vec{\nabla} \vec{\sim} \vec{\nabla}$ in in in in 잉ㅇㅇ응

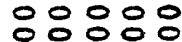

$\infty \times 40$ ×


ON $\infty x$ $\vec{\sim} \vec{N} \vec{N} \vec{N}$ uninin in 잉응 잉ㅇㅇㅇㅇㅇ

บ 
$0 \div+0=$ $m \sim 0 \div \infty$ isiva $\vec{m} \vec{N} \rightarrow 0$ m 23



w山

งัำง - $\cdot 0$ in 0 Nं: N 4 o in

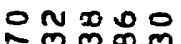
$\sim m m \infty m$ $\sim+N$ in $\sim$ a 00 N N $n$ $\pi t a t$

$0 \infty N \pm 0$ - $\bullet \cdot$ $N \sim \sim \dot{0}$ $\sim 0000$
In유요 - $\cdot \circ \cdot$ $\sim 0000$ - $x$ in $+m m m$

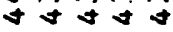

눙요 . iिं $\dot{0} \dot{0}$

un ก! ma $\rightarrow-$ in $\rightarrow$ in
Ninao MNO $\therefore \dot{0} \dot{0} \div$

$\infty$ in $\rightarrow 0 N$



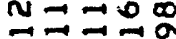
m $m m$ m $+\leqslant m m$

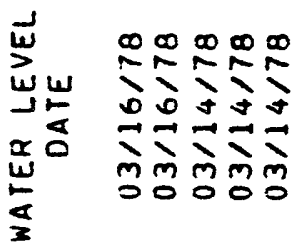

$\infty \infty \infty \infty \infty$ NNN元 in in in 00 $\forall \overrightarrow{V F}$ ओे गे गे ले 00000 $\infty \infty \infty \infty$


$\rightarrow-\rightarrow=1$ ले ले ले के लिलm $\infty \infty \infty \infty$ วิบ 0000 $\rightarrow=0=$ m̄m $\infty \infty \infty \infty \infty$

NN=N

00000

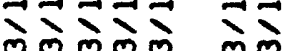

응ㅇㅇㅇㅇㅇㅇㅇㅇ - $\dot{2}$ in: a in in in $m$ m $\stackrel{n}{n}$ ñ $\rightarrow+5$

$\overrightarrow{0} \overrightarrow{0} \overrightarrow{0}$ $\wedge m=60$ $\rightarrow m \vec{n}=$

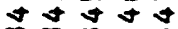
m $m$ ○0잉 $\vec{a} \rightarrow \vec{a}=$


N $\rightarrow-1$

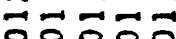
00000
뭉ㄷㅇ웅 ก $N$ un OON $+a t j$ in m 00000 $\overrightarrow{0} \vec{m} \vec{m} \vec{\infty}$ O In ก -1000 뭉ㅎㅇㅎㅇ $\forall+\forall y$
응ㅇㅇㅇㅇㅇㅇㅇㅇㅇ - - in tranin ษ



영영ㅇㅇㅇ i் in: mo $0 \leqslant 0$ $\checkmark \mathrm{m} m$ $\forall \forall m m m$


$\circ$ i 0 in in $m m m \pm m m$

뭉ㅎㅇㅁㅇㅇ - $\rightarrow$ ino anO N a $000-$ $+\Delta$ in in ir. $m m m m$ 00000


$N \pm m \rightarrow$ + $\mathrm{mmm}$ 두유웅 $48+4$



훙ㅎㅇㅇㅠ in $0 x \rightarrow 0$ ON $\forall \vec{\nabla} \vec{a}$ in a $\forall+t$ n लmलmm mm 00000 00 $\overrightarrow{0} \overrightarrow{\overrightarrow{0}} \overrightarrow{\overrightarrow{0}} \overrightarrow{0} \overrightarrow{0}$ in $\vec{n}$ in mo NNN-10 0

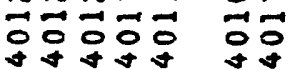

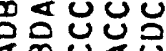
我 NㅜNํำ NNNNN in in in ํํㅇㅇํㅇㅇํㅇ $m \mathrm{~m} m \mathrm{~m}$



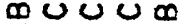
ن $\alpha<0 \infty \infty$ 에 $\vec{m} \tilde{M}=$


in in is. in in


$m m m m m$ 응응ㅇㅇㅇㅇㅇㅇ
ن บบ요 $4<40<$ $n m \& 4$ in $\vec{\omega} \vec{\infty} \vec{\infty} \vec{\omega}$ nin in in 있잉 잉ㅇㅇ잉
눈웅



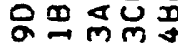
- $N$ N $\infty x \infty \infty$ in un in in 익요응


잉ㅇㅇㅇㅇㅇ
Ф0ن⿺

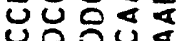
$\rightarrow+8$ in N N N $\infty \infty \infty \infty \infty$ n un un 잉ㅇㅇㅇㅛ 응응ㅇㅇㅇㅇㅇㅇㅇㅇㅇ $\cup 4$ U⿺ in $m m$ $\infty$ un 용 $m m$ ㅇㅇㅇ 